UNIVERSIDADE DE SÃO PAULO

FACULDADE DE FILOSOFIA, LETRAS E CIÊNCIAS HUMANAS DEPARTAMENTO DE LETRAS MODERNAS

PROGRAMA DE PÓS-GRADUAÇÃO EM ESTUDOS LINGUíSTICOS E LITERÁRIOS EM INGLÊS

\title{
DA BIOGRAFIA PARA O PALCO: TRÊS PEÇAS DE THOMAS KILROY
}

São Paulo 2012 
UNIVERSIDADE DE SÃO PAULO

FACULDADE DE FILOSOFIA, LETRAS E CIÊNCIAS HUMANAS DEPARTAMENTO DE LETRAS MODERNAS PROGRAMA DE PÓS-GRADUAÇÃO EM ESTUDOS LINGUÍSTICOS E LITERÁRIOS EM INGLÊS

\section{DA BIOGRAFIA PARA O PALCO: TRÊS PEÇAS DE THOMAS KILROY}

ADRIANA TORQUETE DO NASCIMENTO JUSTINO

Dissertação apresentada ao Programa de PósGraduação em Estudos Linguísticos e Literários em Inglês do Departamento de Letras Modernas da Faculdade de Filosofia, Letras e Ciências Humanas da Universidade de São Paulo, para a obtenção do título de Mestre em Letras.

Orientadora: Prof ${ }^{a}$ Dra. Munira Hamud Mutran

São Paulo 
Com muito amor,

À minha preciosa filha Pietra.

Ao meu esposo e companheiro André.

Aos meus queridos pais Sandra e José. 


\section{AGRADECIMENTOS}

A Deus, que esteve ao meu lado em todos os momentos.

A Thomas Kilroy, por seu imenso talento, gentileza e generosidade.

À Coordenação de Aperfeiçoamento de Pessoal de Nível Superior (CAPES), pela concessão da Bolsa de Mestrado para a realização desta pesquisa.

À Prof ${ }^{-}$Dra. Munira Hamud Mutran, pela orientação segura, amizade, dedicação e incentivo.

À Profa ${ }^{a}$ Dra. Maria Sílvia Betti e ao Prof. Dr. Marco Antônio Guerra, pelas valiosas sugestões na Banca de Qualificação.

À Prof ${ }^{a}$ Dra. Beatriz Kopschitz Xavier Bastos, que despertou meu interesse pela literatura irlandesa e direcionou meus primeiros passos acadêmicos.

À Profa Dra. Laura Patrícia Zuntini Izarra, pelo auxílio e sugestões.

À Prof ${ }^{a}$ Dra. Lenita Maria Rimoli Esteves e à Edite, por toda a atenção.

À minha abençoada família: meus pais Sandra e José, meus sogros Zélia e Isaque e, especialmente, minha filha Pietra e meu esposo André, por todo o incentivo, força e amor.

Às minhas colegas do Grupo de Estudos Irlandeses (GEI): Adriana Capuchinho, Alessandra Rigonato, Rita Köster, Mariese Stankiewicz, Cecília Martins, Doli de Castro, Maria Rita Viana, Mariana Bolfarine e Rosa Erlichman (in memoriam), pela amizade e auxílio. 


\title{
RESUMO
}

A presente dissertação examina a transposição da biografia para o palco em três peças do autor irlandês Thomas Kilroy: Double Cross (1986), The Secret Fall of Constance Wilde (1997) e My Scandalous Life (2004), analisando o modo como o dramaturgo adaptou os registros históricos para a linguagem teatral e explorou as lacunas biográficas por meio de elementos ficcionais; e de que forma foram empregados os recursos épicos na forma dramática. Double Cross baseia-se em duas figuras históricas, Brendan Bracken e William Joyce, que atuaram em lados opostos durante a Segunda Guerra Mundial. The Secret Fall of Constance Wilde transpõe para o teatro episódios da vida de Constance, esposa de Oscar Wilde. O monólogo My Scandalous Life retoma a personagem Lord Alfred Douglas, presente em The Secret Fall of Constance Wilde.

\author{
PALAVRAS-CHAVE
}

THOMAS KILROY-TEATRO IRLANDÊS-BIOGRAFIA-TRANSPOSIÇÃO-ÉPICO 


\section{ABSTRACT}

The present dissertation examines the transposition from biography to stage in three plays by Thomas Kilroy: Double Cross (1986), The Secret Fall of Constance Wilde (1997) e My Scandalous Life (2004), analyzing how the Irish playwright adapted the historical records for theatrical language and filled in the biographical gaps through fictional elements; and how epic features were used in dramatic form. Double Cross is based on two historical figures, Brendan Bracken and William Joyce, who were on opposite sides during the Second World War. The Secret Fall of Constance Wilde transposes events of Constance's life, Oscar Wilde's wife, to the stage. The monologue My Scandalous Life concentrates on Lord Alfred Douglas, also present in The Secret Fall of Constance Wilde.

\section{KEY WORDS}




\section{SUMÁRIO}

INTRODUÇÃO__ 07

CAPÍTULO 1 - Double Cross

A história de dois homens que inventaram a si mesmos 27

CAPÍTULO 2 - The Secret Fall of Constance Wilde Marionetes do Destino 50

CAPÍTULO 3 - My Scandalous Life

Um Outro Lord Alfred Douglas 81

CONSIDERAÇÕES FINAIS 103

BIBLIOGRAFIA 


\section{INTRODUÇÃO}

O teatro irlandês contemporâneo tem produzido excelentes peças e autores, dentre os quais merecem destaque Brian Friel, Thomas Kilroy, Frank McGuinness, Sebastian Barry, Martin McDonagh e Conor McPherson. A obra de Kilroy, em especial, atraiu minha atenção devido à grande qualidade de suas peças, à diversidade de formas e recursos cênicos e à (ainda) pequena fortuna crítica.

Durante um primeiro levantamento, foi possível constatar que, de fato, pouco ou nada se escreveu a respeito de Kilroy em livros de referência sobre literatura irlandesa e grande parte do material crítico estava disperso em vários periódicos. Além disso, sua obra ainda não foi abordada em nenhuma tese ou dissertação no Brasil.

Thomas Kilroy (1934-) é conhecido devido à sua vasta produção dramatúrgica e crítica e por seu único romance The Big Chapel (1971), indicado para o Booker Prize e vencedor do Guardian Fiction Prize e o Heinemann Award; considerado um dos romances irlandeses mais significativos do século XX, The Big Chapel revela o papel da Igreja Católica na Irlanda, tema que o autor retoma em Christ Deliver Us! (2010).

Kilroy nasceu em Co. Killkenny e estudou em University College Dublin (UCD). No início de sua carreira, foi editor de peças no Abbey Theatre e, em 1986, juntou-se à Companhia Teatral Field Day. Atuou como professor de 
inglês no University College em Galway, cargo que deixou em 1989 para dedicar-se à atividade de escritor e de crítico literário. Atualmente, vive em Co. Mayo e é membro da Irish Academy of Letters, da Royal Society of Literature e Aosdána. Grande parte de sua obra concentra-se no teatro, com dezesseis peças produzidas; no entanto, duas ainda não foram publicadas (Blake e Dreaming House).

A primeira a ser encenada foi The Death and Resurrection of Mr Roche (1968); rejeitada, a princípio, pelo Abbey Theatre, obteve sucesso no Dublin Theatre Festival em 1968. A ação tem início com a chegada de Mr. Roche, homossexual misterioso, num bar onde alguns amigos estão bebendo e conversando. A peça contém certa violência e um dos focos principais é o triste solteirão Kelly em sua jornada interior à própria sexualidade.

Um tema recorrente em algumas das peças de Kilroy é "O Artista". Tea and Sex and Shakespeare (1976) é uma comédia surreal sobre a solidão de um escritor que é vítima de sua imaginação e não consegue trabalhar devido aos pesadelos e alucinações. De fato, é uma peça excelente em que o limite entre o real e o imaginário desaparece, os muros se abrem e um velho armário torna-se uma caixa mágica de onde emergem várias personagens.

The Madame MacAdam Travelling Theatre (1991) relata os acontecimentos após a chegada de um pequeno grupo teatral itinerante inglês a uma cidadezinha irlandesa provinciana durante a Segunda Guerra Mundial. É uma peça engraçada e tocante, que aborda as paixões e os conflitos entre os artistas e os moradores da cidade.

The Shape of Metal (2003) conta a história de Nell Jeffrey, artista e mãe, inescrupulosa, apaixonada e muito inteligente. Acompanhamos seu 
relacionamento com suas duas filhas, Judith, que permanece ao seu lado, e Grace, que desaparece. The Shape of Metal explora a natureza da arte, contudo também é um retrato emocionante de três mulheres em uma família.

A obra dramatúrgica de Kilroy inclui ainda cinco adaptações/versões de obras clássicas da literatura mundial: The Seagull (After Chekhov) (1981), Ghosts (After Ibsen) (1989), Henry ( After Pirandello) (2007), Six Characters in Search for an Author (2007) e Christ Deliver Us! (After Wedekind) (2009), baseada em Spring Awakening. De acordo com o autor, quatro delas são denominadas "After" porque o termo "sugere que a versão nova apresenta mudanças significativas (tempo/espaço e até mesmo o enredo) em relação ao original." Em relação a Six Characters, ele afirma que considera sua versão mais próxima do original do que, por exemplo, Henry e por isso não a denominaria "After", observando que sua maior contribuição foi em termos de linguagem ${ }^{1}$. É relevante salientar que todas as versões foram encomendadas por diretores artísticos de companhias teatrais específicas, que solicitaram versões irlandesas das obras canônicas e, no caso de Henry, uma versão americana. $^{2}$

Em The Seagull, baseada no clássico de Anton Chekhov (1860-1904), Thomas Kilroy transpõe a ação da Rússia para o oeste da Irlanda no final do

\footnotetext{
1 "[...] implies that the new version has made significant changes (setting, even plotting) to the original. I would see my version of Six Characters as closer to the original than, say, Henry and therefore I wouldn't describe it as 'After'. The main contribution of mine to Six Characters has to do with language where my use of language tends to be very Irish." (email, 31 de março de 2012)

2 "Firstly, I would have known all these plays beforehand from productions of English language versions on stages in Ireland, the UK and the United States. Secondly, each version would have been commissioned by a particular theatre where the Artistic Director of each theatre would have approached me and asked me to do a new version, usually along very particular lines (an Irish version, for example or, as in the case of Henry, an American version). The customary practice with translation is that the theatre commissions a new literal translation for each first production, that is a translation as close as possible to the original. Very often the theatre also employs a specialist with a knowledge of the original and the language, who is available for discussion as problems arise. I would also know other translations of each of the plays before starting." (email, 31 de março de 2012)
} 
século XIX. Como várias versões que obtiveram sucesso, The Seagull é um tributo à sua fonte e muitos aspectos do texto original permaneceram, tais como a caracterização, o enredo e a história central de um amor condenado. Em seu esboço sobre a história irlandesa, o declínio do estado Anglo-Irlandês e a Land League, Kilroy encontrou paralelos com as mudanças políticas e sociais russas encontradas na obra original.

Em sua versão de Ghosts (1881) de Heinrik Ibsen (1828-1906), Kilroy examina como os pecados de um pai são refletidos nos filhos em uma família assombrada por fantasmas. Em Six Characters in Search for an Author (1996), de Luigi Pirandello (1867-1936), um grupo de personagens visita um teatro durante os ensaios provocando uma mistura de realidade e ilusão. Henry (2005) relata a trajetória de um homem moderno que assume a identidade de um imperador alemão.

Christ Deliver Us! transpõe a tragédia da Alemanha do fim de século XIX para a atmosfera igualmente repressiva da Irlanda pós-Segunda Guerra Mundial. No interior e nas proximidades de um Colégio Católico Diocesano e uma Escola Industrial para garotos problemáticos, Kilroy explora as incertezas e frustrações do despertar da sexualidade, as pressões de pais e professores, que abusam da autoridade e os agridem. Assim como Wedekind, Kilroy toma cuidado para não moralizar nem condenar.

Apesar de sua vasta produção dramatúrgica, a fortuna crítica de Kilroy é relativamente pequena, composta principalmente por artigos em periódicos e alguns comentários em obras críticas sobre o teatro irlandês. $\mathrm{O}$ único livro publicado sobre sua dramaturgia é The Plays of Thomas Kilroy: A critical study (2007), em que o professor Thierry Dubost aborda temas e aspectos presentes 
em suas peças. Na primeira parte (The Plays), Dubost dedica um capítulo a cada peça, com exceção de The Death and Resurrection of Mr. Roche e The MacAdam Travelling Theatre, cujos temas complementares são discutidos juntamente. A segunda parte da obra, dedicada às entrevistas com Kilroy e alguns diretores que trabalharam com ele, contém informações valiosas sobre a composição e o contexto de produção de suas peças.

No artigo "Impossible Promise: The Child and the Androgyne in Thomas Kilroy's The Secret Fall of Constance Wilde and My Scandalous Life", publicado no periódico llha do Desterro (2010), Jose Lanters explora o ideal de harmonia perfeita entre os sexos e da inocência simbolicamente representadas pelas figuras do Andrógino e da criança nas peças. Segundo a autora, no processo que ilustra o paradoxo Wildeano ("cada homem mata o que ama"), Oscar e Constance Wilde de um lado, Alfred Douglas e Olive Custance de outro, lutam pela posse dos filhos, destruindo o ideal da harmonia andrógina e da inocência infantil e, somente dessa forma, conseguem restaurar algum equilíbrio em suas vidas.

Uma edição especial do Irish University Review: a journal of Irish Studies sobre Thomas Kilroy foi publicada em 2002, com contribuições de Nicholas Grene, Anna McMullan, Hiroko Mikami, Patrick Mason, Thierry Dubost e outros críticos.

Em "Staging the self: person and persona in Kilroy's plays", Grene comenta sobre as personagens centrais de três peças baseadas na história e biografias: Matt Talbot em Talbot's Box, Brendan Bracken e William Joyce em Double Cross, Constance Wilde, Oscar Wilde e Lord Alfred Douglas em The Secret Fall of Constance Wilde. Segundo Grene, o que interessa a Kilroy não é 
a realidade mas a teatralização de vidas reais, visto que as personagens são criações do dramaturgo. Dessa forma, as obras possuem grande valor artístico e limitado valor histórico. Vale ressaltar que esse artigo foi de fundamental importância para o início da presente pesquisa pois aborda justamente a relação entre as biografias e as peças, e discute conceitos como teatralização e valor histórico/artístico.

Anna McMullan, em "Masculinity and Masquerade in Thomas Kilroy's Double Cross and The Secret Fall of Constance Wilde", afirma que desde Tea, Sex and Shakespeare (1976) Kilroy tem explorado a teatralidade e a performance da identidade. De acordo com McMullan, Kilroy tem usado formas teatrais tão diversas como o teatro épico de Brecht e o Bunraku, o teatro japonês de marionetes, combinando texto com imagens, mídia e marionetes e criando um complexo jogo teatral que rejeita as convenções realistas de identidade, espaço cênico e enredo. Além disso, a autora discute os conceitos de pantomima e máscaras na representação teatral de gênero, criatividade e performance. A discussão levantada por Anna McMullan contribuiu de forma decisiva para o desenvolvimento deste estudo, na medida em que aborda as diversas formas e artifícios teatrais utilizados pelo dramaturgo irlandês.

No artigo "Kilroy's vision of doubleness: the question of national identity and theatricality in Double Cross", Hiroko Mikami relata a trajetória do Field Day Theatre Company desde 1980, quando a peça Translations, de Brian Friel, foi um sucesso de público e crítica, até o início dos anos 90. Posteriormente, Mikami comenta sobre o enredo de Double Cross, analisando a estrutura da peça, cenários e, como indica o título, os artifícios teatrais utilizados por Kilroy. Esse artigo apresenta mais comentários expositivos e explicativos do que 
propriamente críticos; entretanto, sua leitura auxiliou-me na análise dos recursos cênicos.

Em "Acting out", Patrick Mason, diretor das primeiras montagens de Talbot's Box e The Secret Fall of Constance Wilde, escreve sobre sua experiência ao lado de Kilroy e sobre a composição de The Secret Fall. Na segunda metade do artigo, Mason faz uma excelente análise da peça.

Outro artigo da edição especial do Irish University Review relacionado ao tema desta dissertação é "Kilroy's theatre of the conflicted self", em que Thierry Dubost observa que todas as obras de Kilroy apresentam algum tipo de conflito, interior ou exterior, e, inclusive, três acontecem em períodos de guerra (Double Cross, The O'Neill e The Madame MacAdam Travelling Theatre). Além dos conflitos específicos expostos em cada peça, Dubost analisa o que esses conflitos significam e representam filosoficamente, associando-os à identidade irlandesa.

Diante da fortuna crítica exposta, optei por pesquisar um aspecto presente em cinco de suas peças e que representa uma verdadeira tendência no teatro contemporâneo: as biografias no palco. Na verdade, já há uma longa tradição do uso da biografia no teatro. Temos exemplos nas encenações medievais sobre a "vida dos santos" e figuras bíblicas, nas peças históricas de Shakespeare, entre outros. No teatro contemporâneo, todavia, podemos notar uma tendência de peças biográficas preocupadas em desmitificar seus protagonistas. Por exemplo, The Patriot Game (1991), do dramaturgo irlandês 
Tom Murphy, apresenta uma crítica irônica aos heróis nacionalistas do Levante de Páscoa ${ }^{3}$ de 1916, como Patrick Pearse e Thomas MacDonagh.

Thomas Kilroy escreveu cinco peças baseadas em biografias: The O'Neill (1969), Talbot's Box (1979), Double Cross (1986), The Secret Fall of Constance Wilde (1997) e My Scandalous Life (2004). No entanto, esta pesquisa abordará as últimas três. The O’Neill foi baseada na biografia de Hugh O'Neill, The Great O’Neill, escrita pelo autor irlandês Sean O'Faolain em 1942. Trata-se, na verdade, do primeiro indício desse aspecto recorrente em sua obra: fontes biográficas. The O'Neill dramatiza a vida de uma figura histórica irlandesa do século XVI, Hugh O'Neill (1540-1616), o Conde de Tyrone, cuja derrota para os ingleses na Batalha de Kinsale em 1601 leva à dissolução da antiga ordem irlandesa de governo. Kilroy fixa seu olhar no relacionamento entre os colonizadores e os colonizados, pois ele considera esse evento um dos mais traumáticos da história irlandesa, cujas conseqüências se estendem até hoje. É uma peça que não apresenta grandes rupturas com as formas tradicionais de encenação e com uma narrativa linear.

Em Talbot's Box podemos reconhecer certas características do teatro de Kilroy, como a suspensão da realidade por meio de cenários e personagens, ou um único ator desempenhando vários papéis e funções. O enredo é baseado na figura histórica de Matt Talbot (1856-1925), religioso que nasceu e viveu em Dublin e que, até os 28 anos, foi alcoólatra. Após sua conversão, passou a viver uma rotina que duraria mais de 40 anos, orando de joelhos com correntes presas ao corpo.

\footnotetext{
${ }^{3}$ O Levante de Páscoa (Easter Rising) foi uma rebelião organizada por militantes republicanos irlandeses a fim de conquistar a Independência em relação ao Reino Unido.
} 
Double Cross e The Secret Fall of Constance Wilde são consideradas obras marcantes para o teatro contemporâneo. Tal fato é ratificado pela fortuna crítica de Kilroy, pois a maioria dos artigos e comentários refere-se particularmente às duas peças citadas e, inclusive, The Secret Fall of Constance Wilde já assumiu, segundo a mídia, o status de clássico no cenário irlandês. Já a mais recente, o monólogo My Scandalous Life, ainda não foi abordada de modo significativo pelos periódicos, porém é indiscutivelmente uma peça de qualidade e retoma um personagem de The Secret Fall of Constance Wilde, Lord Alfred Douglas. Dessa forma, observa-se uma grande relação entre as duas obras.

Além disso, as três estão próximas cronologicamente na produção (1986, 1997 e 2004) e na ação: Double Cross, nos primeiros anos da década de 1940; The Secret Fall of Constance Wilde, no período de 1895 a 1900, ou seja, últimos anos da vida de Constance e Oscar Wilde; e My Scandalous Life em 1944.

É importante salientar que as peças escolhidas apresentam vários traços épicos, tais como: referência a elementos externos (biografia e história), narradores implícitos e explícitos, sequências narrativas, quebra da atualidade cênica, direcionamento ao público, suspensão da ilusão, entre outros. Aliás, na introdução à Double Cross, Thomas Kilroy comenta que o estilo da peça aproxima-se do Teatro Brechtiano. (1994, p.14)

A fim de analisar tais recursos, utilizaremos duas obras fundamentais para o estudo do teatro épico: Teoria do Drama Moderno (2001), de Peter Szondi, e O Teatro Épico (2006), de Anatol Rosenfeld. 
Szondi, na obra acima citada, relata o avanço dos traços épicos à forma dramática a partir de meados do século XIX. Segundo o autor, o drama puro aristotélico é absoluto e primário; além disso, o dramaturgo está ausente e há o domínio absoluto do diálogo. Partindo desses princípios, Szondi reflete sobre a crise do drama, analisando Ibsen, Chekhov, Strindberg, Maeterlinck e Hauptmann; e verificando a contradição crescente entre a forma do drama e os novos conteúdos. Na sequência, o autor aponta as "tentativas de salvamento" da forma dramática, examinando o naturalismo, a peça de conversação, a peça de um só ato, o confinamento e o existencialismo. Por fim, aborda as "tentativas de solução" da crise do drama, em que analisa a obra de dramaturgos como Brecht, Pirandello, O'Neill e Miller.

Em O Teatro Épico, Rosenfeld, também partindo da teoria dos gêneros, analisa os recursos épicos empregados por movimentos teatrais, dramaturgos e diretores, desde a Idade Média até o Teatro Épico Brechtiano, passando pelo Barroco, Teatro Elisabetano, Romantismo e Naturalismo. Segundo Rosenfeld, o uso de recursos épicos não é arbitrário, mas corresponde a "transformações históricas que suscitam o surgir de novas temáticas, novos problemas, novas valorações e novas concepções de mundo" (2006, p.12). Além disso, podemos afirmar que vários aspectos narrativos/épicos nas peças de Kilroy justificam-se pelo fato de serem peças baseadas em biografias, ou seja, um gênero narrativo.

Apresentadas as devidas justificativas e critérios de escolha, chegamos ao objeto desta pesquisa: a transposição de biografias para o palco. Pretendemos, a princípio, verificar nas peças possíveis dados biográficos transpostos e/ou recursos teatrais utilizados para sugeri-los. 
Também visamos pesquisar e reconhecer nas prováveis fontes utilizadas pelo autor os aspectos explorados nas peças e, principalmente, analisar de que forma deu-se o processo de transposição, refletindo sobre as escolhas do autor. Ou seja, o que o ele enfatizou, criou ou omitiu? Como? Quais recursos teatrais foram utilizados? Para quais efeitos?

Além disso, tem-se como objetivo analisar de que forma as lacunas biográficas foram exploradas, buscando compreender e refletir sobre os mecanismos de transposição de um gênero tão específico como a biografia para a linguagem teatral, bem como verificar as características épicas de cada peça. Por fim, a presente pesquisa tem o intuito de divulgar a obra de Thomas Kilroy para o público brasileiro.

É pertinente aqui apresentar alguns conceitos de biografia e refletir sobre sua importância como documento histórico e gênero literário. Afinal quais são os "limites" da biografia, ou seja, até que ponto deve ser fiel à realidade e até que ponto pode conter elementos ficcionais? Ou poderíamos afirmar que nenhuma biografia é totalmente "fiel" à realidade, pois passa pela interpretação e pelas escolhas do biógrafo?

Respondendo às questões acima, Décio Pignatari afirma que "há biógrafos austeros, que são factuais e só acreditam no documento (se possível, com firma reconhecida)"3; no entanto, há alguns que incluem vários elementos ficcionais. Ainda de acordo com Pignatari, "a biografia é um romance documental e documentado". (1996, p.14)

Para escrever uma biografia ou uma peça biográfica, é necessária a consulta de materiais diversos. Segundo Hisgail, "a empreitada do biógrafo

\footnotetext{
${ }^{4}$ PIGNATARI, Décio. "Para uma semiótica da biografia". In: Biografia: Sintoma da Cultura. São Paulo: Hacker Editores: Cespuc, 1996, p.16.
} 
envolve documentos, diários, depoimentos de testemunhas, correspondências, fotografias e tudo o que possa ser útil sobre a vida do biografado."

Em O Desafio Biográfico: Escrever uma Vida (2009), François Dosse afirma que a biografia se situa na tensão constante entre a vontade de reproduzir um passado real vivido e o polo imaginativo do biógrafo, que deve refazer um universo perdido segundo sua intuição e talento criador. Segundo Dosse,

O gênero biográfico encerra o interesse fundamental de promover a absolutização da diferença entre um gênero propriamente literário e uma dimensão puramente científica - pois, como nenhuma outra forma de expressão, suscita a mescla, o caráter híbrido, e manifesta assim as tensões e as conivências existentes entre a literatura e as ciências humanas. (p. 18)

O autor reflete também sobre a diferença entre biógrafo e romancista (no nosso caso, dramaturgo), constatando que "o biógrafo tem uma deficiência com relação ao romancista na medida em que não pode evocar a vida interior de sua personagem. Faltam-Ihe as fontes que Ihe permitiriam penetrá-la, ao passo que o romancista sempre dá largas à fantasia" (2009, p.60).

Observa-se nas peças escolhidas que o dramaturgo não se limitou a colocar em cena episódios biográficos de forma linear, preferindo, ao contrário, assimilar os elementos e reelaborá-los de forma livre. Comentando sobre a intertextualidade e essa forma de assimilação de discursos, Leyla PerroneMoisés afirma:

A intercomunicação dos discursos não é algo novo. O que é novo é que o recurso a textos alheios se faça sem preocupação de fidelidade (imitação), ou de contestação simples (paródia ridicularizante), sem o

\footnotetext{
${ }^{5}$ HISGAIL, Fani. "Aparte biográfico". In: Biografia: Sintoma da Cultura. São Paulo: Hacker Editores: Cespuc, 1996, p.8.
} 
estabelecimento de distâncias claras entre o original autêntico e a réplica, sem respeito a qualquer hierarquia dependente da 'verdade'. O que é novo é que essa assimilação se realize em termos de reelaboração ilimitada da forma e do sentido, em termos de apropriação livre, sem que se vise o estabelecimento de um sentido final (coincidente ou contraditório com o sentido do discurso incorporado). (1978, pp. 59-60)

A reelaboração ilimitada da forma e do sentido citada acima condiz perfeitamente com o processo realizado pelo autor irlandês, pois, como veremos adiante, seu intuito, apesar da exaustiva pesquisa a fontes biográficas, não é a mera reconstituição de fatos, mas a composição de uma obra de arte.

Dessa forma, visa-se aqui analisar o modo como ocorreu a produção deste texto novo (no caso, as peças em estudo), recorrendo à teoria da intertextualidade de Julia Kristeva. De acordo com Leyla Perrone-Moisés:

Retomando as propostas de Bakhtin, Julia Kristeva concebeu e nomeou a teoria da intertextualidade. Segundo Kristeva, 'todo texto se constrói como um mosaico de citações, todo texto é absorção e transformação de textos; ele é uma escritura-réplica (função e negação) de outro (dos outros) texto(s)'. O objetivo dos estudos de intertextualidade é examinar de que modo ocorre essa produção do novo texto, os processos de rapto, absorção e integração de elementos alheios à criação da obra nova. Para Kristeva, portanto, as 'fontes' deixam de interessar por elas mesmas; elas só interessam para que se possa verificar como elas foram usadas, transformadas. (1990, p.94)

Linda Hutcheon, em A Theory of Adaptation (2006), trata especificamente de formas e métodos de transposição e adaptação entre vários gêneros e mídias. Segundo a autora:

A maioria das teorias de adaptação assume, no entanto, que a história é o denominador comum, o núcleo do que é transposto através de mídias e gêneros diferentes, cada qual lida com a história 
de maneira formalmente diferente e, eu acrescentaria, através de modos diferentes de apresentação - narrar, representar, ou interagir. ${ }^{6}$

A autora afirma e reafirma em vários momentos que um adaptador deve primeiramente interpretar o texto fonte para, em seguida, criar "algo novo":

O que está envolvido em adaptar pode ser o processo de apropriação, de tomar posse da história alheia, e filtrá-la, de certo modo, através da própria sensibilidade, interesses, e talentos. Portanto, os adaptadores são primeiramente intérpretes e então criadores. [...] Seja qual for o motivo, da perspectiva do adaptador, a adaptação é um ato de apropriação ou recuperação, e este é sempre um processo duplo de interpretar e então criar algo novo. ${ }^{7}$

Todavia, não se trata apenas de transpor de um gênero para o outro, ou de uma mídia para outra, de forma simplificada, pois este processo dependerá das escolhas, do temperamento e do talento do adaptador:

O texto adaptado não é algo a ser reproduzido, mas sim algo a ser interpretado e recriado, geralmente em uma nova mídia. Mas a transposição criativa da história em uma obra adaptada e seu heterocosmo é assunto não apenas para as demandas do gênero e da mídia, mas também do temperamento e talento do adaptador - e seus intertextos individuais através dos quais são filtrados os materiais que estão sendo adaptados. ${ }^{8}$

\section{Esta afirmação coincide com as palavras de Kilroy em uma entrevista}

\section{concedida em 1986 (antes da estreia de Double Cross no Gate Theatre em}

\footnotetext{
6 "Most theories of adaptation assume, however, that the story is the common denominator, the core of what is transposed across different media and genres, each of which deals with that story in formally different ways and, I would add, through different modes of engagement narrating, performing, or interacting." (p.10) (Obs: As traduções dos textos em inglês ao longo deste trabalho, salvo indicação em contrário, foram feitas pela autora.)

7 "What is involved in adapting can be a process of appropriation, of taking possession of another's story, and filtering it, in a sense, through one's own sensibility, interests, and talents. Therefore, adapters are first interpreters and then creators. [...] Whatever the motive, from the adapter's perspective, adaptation is an act of appropriating or salvaging, and this is always a double process of interpreting and then creating something new." (2006, pp. 18-20)

8 "The adapted text is not something to be reproduced, but rather something to be interpreted and recreated, often in a new medium. But the creative transposition of an adapted work's story and its heterocosm is subject not only to genre and medium demands, but also to the temperament and talent of the adapter - and his or her individual intertexts through which are filtered the materials being adapted." (HUTCHEON, 2006, p.84)
} 
Dublin), na qual ele afirma que é fascinado pela releitura da história por meio da ficção. Segundo ele, "deve-se absorver a história para então escapar dela. No momento em que você começa a escapar é quando você cria algo." ${ }^{9}$

A transposição, neste caso, é de um gênero que conta uma história (a biografia) para um que mostra uma história (o teatro). Explanando de forma didática, Hutcheon explica algumas diferenças:

Contar uma história, como em romances, contos, e até mesmo relatos históricos, é descrever, explicar, resumir, expandir; o narrador tem um ponto de vista e o grande poder de saltar no tempo e no espaço e às vezes se aventurar dentro da mente das personagens. Mostrar uma história, como em filmes, balés, peças, musicais e óperas, envolve uma aura direta e geralmente uma representação visual realizada em tempo real. ${ }^{10}$

Aprofundando-se nesse aspecto da transposição, Hutcheon afirma:

Na mudança do contar para o mostrar, uma adaptação performática deve dramatizar: descrição, narração, e pensamentos representados devem ser transcodificados em fala, ações, sons, e imagens visuais. Os conflitos e diferenças ideológicas entre as personagens devem ser visíveis e audíveis. No processo de dramatização há inevitavelmente uma certa quantidade de re-acentuação e reorientação de temas, personagens e enredo. ${ }^{11}$

\section{Em Palimpsests: Literature in the Second Degree (1997), Gérard}

Genette analisa a transtextualidade, identificando cinco categorias:

intertextualidade, paratexto, metatextualidade, arquitextualidade e

\footnotetext{
9 "I'm fascinated with the whole re-reading of history through fiction. You have to absorb the history and then escape from it. And the time at which you begin to escape is the time when you create something." Ciaran Carty, 'Kilroy was here', Sunday Tribune, 20 April 1986.

10 "To tell a story, as in novels, short stories, and even historical accounts, is to describe, explain, summarize, expand; the narrator has a point of view and great power to leap through time and space and sometimes to venture inside the minds of characters. To show a story, as in movies, ballets, radio and stage plays, musical and operas, involves a direct aural and usually visual performance experienced in real time." (2006, p.13)

11 "In the move from telling to showing, a performance adaptation must dramatize: description, narration, and represented thoughts must be transcoded into speech, actions, sounds, and visual images. Conflicts and ideological differences between characters must be made visible and audible. In the process of dramatization there is inevitably a certain amount of reaccentuation and refocusing of themes, characters and plot." (2006, p.40)
} 
hipertextualidade, sendo essa última a mais abordada pelo autor. De acordo com Genette, a hipertextualidade é a relação que une um texto B (hipertexto) a um texto A (hipotexto), do qual ele surgiu (1997, p.5); para o autor, a categoria hipertextual mais importante é a transposição, definida como um hipertexto (texto derivado de um texto anterior por meio de transformação simples) com modificações sérias, ou seja, não se trata de imitações lúdicas ou satíricas como a paródia, outra categoria hipertextual (1997, p.212). Segundo o teórico, a transposição pode ser formal, quando envolve o gênero textual ou o idioma, e/ou temática.

Julie Sanders, em Adaptation and Appropriation (2006), oferece uma série de definições e modos de refletir sobre adaptação e apropriação como prática e processo. O objetivo da autora é ampliar a série de termos e suas aplicações, e não fixar ou ossificar conceitos específicos. A autora observa que adaptações e apropriações podem variar no modo como explicitam a intertextualidade: a maioria das adaptações são declaradamente interpretações ou releituras de um precursor canônico, o que pode envolver uma visão pessoal do adaptador e algum tipo de atualização ou relocação cultural. Em apropriações, a relação intertextual pode ser menos explícita e mais embutida (2006, p.2).

Outro aspecto importante apontado é a variabilidade de termos utilizados para designar adaptação ou apropriação: versão, variação, interpretação, transposição, revisão, reescritura, empréstimo, assimilação, influência, alusão, hipertexto, entre outros (2006, p.18).

Sanders, citando Cartmell (1999, p.24), apresenta três categorias de adaptação: a transposição, o comentário e a analogia. A transposição seria a 
relocação cultural dos textos-fonte, em termos socioculturais, geográficos ou temporais; o comentário seria a adaptação que comenta de forma politizada o texto-fonte, geralmente alterando-o ou adicionando elementos; na terceira categoria, a analogia, há uma variação ou reelaboração do texto-fonte e, apesar de análogo em alguns aspectos, não é preciso, segundo a autora, um pré-conhecimento do texto-fonte para a plena compreensão da obra adaptada. No entanto, a necessidade de conhecimento prévio é algo discutível, visto que em nenhuma modalidade de adaptação ou apropriação existe, de fato, essa necessidade real.

A princípio, as peças em questão podem ser consideradas adaptações de biografias, visto que, segundo Sanders, a adaptação é "frequentemente um processo específico envolvendo a transição de um gênero a outro: [...] a dramatização de narrativas em prosa" ${ }^{\text {"2 }}$. Especificamente, poderíamos considerá-las transposições ou comentários, pois Thomas Kilroy, além de transpor as biografias, também altera e adiciona elementos.

Em contrapartida, também podemos classificá-las como apropriações, visto que não há referências explícitas às biografias utilizadas e há uma reformulação dos textos-fonte, o que, segundo Sanders, é intrínseco à apropriação (p.28). É importante salientar que a autora comenta, nos últimos capítulos, sobre a apropriação do fato histórico, discussão que será abordada posteriormente.

Após um prévio levantamento sobre o material biográfico referente às personagens das peças em estudo, constatou-se que há várias biografias e referências a Brendan Bracken e William Joyce, protagonistas da peça Double

\footnotetext{
12 "[...] frequently a specific process involving the transition from one genre to another: [...] the dramatization of prose narrative." (p.19)
} 
Cross, em enciclopédias e livros de história. Também há material considerável sobre outros personagens dessa peça, tais como Lord Castlerosse, Lord Beaverbrook e Margaret Joyce (esposa de William Joyce).

Em relação à The Secret Fall of Constance Wilde e My Scandalous Life, o material biográfico é muito mais numeroso. Oscar Wilde, Constance Wilde e Lord Alfred Douglas foram polêmicos e tiveram vidas trágicas. Devido a isso, já foram assunto de várias biografias, romances e peças.

Diante do vasto material biográfico encontrado, constatei que uma possível saída para esse impasse seria entrar em contato com o autor para indagá-lo sobre as fontes biográficas utilizadas de fato e, além disso, aproveitar para sanar outras dúvidas. Felizmente, Thomas Kilroy, que além de ser um talentoso autor, é também uma pessoa admirável, mostrou-se sensível à minha causa e sempre muito gentil e atencioso. No primeiro contato, questionei-o sobre as fontes biográficas utilizadas, listando várias biografias e livros encontrados. Em email enviado em 20 de abril de 2010, Kilroy citou algumas fontes para as peças e comentou sobre o processo de composição de The Secret Fall of Constance Wilde. A consulta ao protagonista desta pesquisa, Thomas Kilroy, foi essencial para o bom andamento da mesma.

Em relação à estrutura da dissertação, no primeiro capítulo, será abordada Double Cross. Ambientada durante a II Guerra Mundial (1939-1945), a peça relata aspectos das vidas de dois homens de origem irlandesa que negaram suas raízes e acabaram, ironicamente, em lados opostos durante a Guerra: Inglaterra e Alemanha. Brendan Bracken, irlandês que se une aos ingleses e, mais tarde, torna-se Ministro da Informação e amigo do Primeiro Ministro Britânico Winston Churchill; o outro lado do espelho criado por Kilroy é 
William Joyce, americano filho de pai irlandês e que vai morar na Irlanda com apenas três anos de idade. Já adolescente, vai para a Inglaterra e une-se aos Fascistas Britânicos. Durante a Guerra, trabalha fazendo propaganda nazista no rádio. É nessa época que fica conhecido como Lord Haw Haw.

A introdução e o início da peça mostram claramente que a intenção de Kilroy não era recompor fatos e nem ser totalmente fiel aos registros históricos. No entanto, o autor destaca vários aspectos biográficos, incluindo passagens da infância, relacionamentos amorosos e intrigas durante a II Guerra Mundial para compor Double Cross. Na verdade, essa peça é uma dura crítica ao nacionalismo extremo e ao Fascismo.

No segundo capítulo será analisada The Secret Fall of Constance Wilde (1997), que transpõe episódios da vida de Constance, esposa de uma das figuras mais polêmicas da literatura mundial, Oscar Wilde. Nessa peça, além de assistirmos à trágica queda (física, moral e financeira) da protagonista, numa mistura de fatos e especulação, também acompanhamos a decadência pública e pessoal de Oscar, fruto de seu relacionamento com Lord Alfred Douglas.

O monólogo My Scandalous Life, que retoma a personagem Lord Alfred Douglas da segunda peça estudada, será discutido no terceiro capítulo. Ao invés de jovem e ousado, ele é agora um homem com setenta e quatro anos repleto de frustrações, problemas e mentiras.

The Secret Fall of Constance Wilde e My Scandalous Life possuem elementos em comum; no entanto, optou-se por dedicar um capítulo a cada peça devido à riqueza de aspectos a serem analisados. O último capítulo será reservado às Considerações Finais, em que serão apontados, além das 
conclusões obtidas ao longo dos capítulos, os pontos semelhantes e divergentes nas peças abordadas.

Como veremos a seguir, Double Cross é um exemplo de apropriação dos registros históricos e biográficos a fim de estabelecer um paralelo com questões contemporâneas à data de produção da mesma. 


\title{
CAPÍTULO 1
}

\section{DOUBLE CROSS:}

\section{"A história de dois homens que inventaram a si mesmos"}

\section{When a man wipes out his past and invents his own future he may have criminal or artistic tendencies.}

Em Double Cross, Thomas Kilroy relata aspectos das vidas de William Joyce e Brendan Bracken baseando-se em registros históricos e biografias; entretanto, o autor adicionou vários elementos ficcionais, frutos de seu talento e poderosa imaginação. Na introdução da peça, escrita para a edição de 1994, o dramaturgo afirma que seu intuito não era ser fiel aos registros biográficos e que não havia nenhuma evidência de que Brendan Bracken e William Joyce teriam se conhecido pessoalmente, nem mesmo que um soubesse da existência do outro. Para ele,

\begin{abstract}
Eles são simplesmente parte de uma rede histórica de possibilidades irônicas. Eu os coloquei juntos nessa peça para que eles pudessem habitar uma única ideia dramática. Essa é a noção de que dois homens que negaram e esconderam tão espetacularmente suas origens podem dramatizar as deformidades do nacionalismo de forma mais eficaz do que dois patriotas. Eu os fiz antagonistas na peça onde eles realizam um espécie de Segunda Guerra Mundial pessoal. ${ }^{13}$
\end{abstract}

\footnotetext{
13 "They are simply part of history's web of ironical possibilities. I've yoked them together in this play so that they might inhabit the one dramatic idea. This is the notion that two men who so spectacularly denied and concealed their native origins might dramatize the deformities of nationalism more effectively than two patriots. I have made them antagonists in the play where they carry out a kind of personal World War II of their own." (1994, p.11)
} 
Salientando esse aspecto, os narradores alertam o público no início da peça: "ATRIZ - Senhoras e Senhores! Nós não podemos garantir a precisão de nada que se seguirá./ ATOR - Até mesmo do que é verificável nos livros de história."14 Observa-se que, apesar do autor ter se apropriado de alguns elementos dos registros biográficos, o resultado que se tem em cena é algo distinto dos textos-fonte e repleto de elementos ficcionais.

Entretanto, não podemos ignorar aqui as biografias, visto que serviram de sólida base para a composição da obra e foram citadas pelo próprio autor em email enviado em 2010: Lord Haw Haw and William Joyce: the full story (1964), de J. A. Cole, Brendan Bracken (1979), de Charles Edward Lysaght, Beaverbrook (1972), A. J. P. Taylor e The New Meaning of Treason (1985), de Rebecca West que afirma que "a ideia de um traidor tornou-se real pela primeira vez para os britânicos de nossa época quando eles ouviram a voz de William Joyce no rádio durante a guerra." ${ }^{15}$

Double Cross foi produzida pelo Field Day Theatre Company, sediada em Derry, em fevereiro de 1986. Também foi produzida pelo Royal Court Theatre, em Londres, em maio do mesmo ano. No artigo "Staging the self: person and persona in Kilroy's plays"16 escrito para o Irish University Review: a Journal of Irish Studies (2002), Nicholas Grene observa que Double Cross foi escrita para a Companhia Teatral Field Day e especificamente para o ator Stephen Rea. Segundo o crítico, foi um ajuste perfeito entre a peça e a companhia, entre a concepção do dramaturgo e os princípios políticos do Field

\footnotetext{
14 "ACTRESS - Ladies and gentlemen! We cannot vouch for the accuracy of anything that is going to follow.

ACTOR - Even of what is verifiable in the history books." (p.27)

15 "The idea of a traitor first became real to the British of our time when they heard the voice of William Joyce on the radio during the war." (1985, p.3)

16 "Staging the self: person and persona in Kilroy's plays". Irish University Review: a journal of IrishStudies,2002.FindArticles.com.05Jun,2010.http://findarticles.com/p/articles/mi_hb162/is_1_ 32/ai_n28971099/
} 
Day, que produzia uma nova peça a cada ano e embarcava em uma turnê pela Irlanda simbolizando a recusa em aceitar a separação entre as duas Irlandas. Grene observa também que o objetivo do teatro de Kilroy é compreender e não julgar:

\begin{abstract}
No caso de Double Cross, isso envolvia a compreensão de Lord Haw Haw, o propagandista nazista que foi enforcado, numa perspectiva em que suas motivações e ações pudessem ser vistas como comparáveis às de Brendan Bracken, elevado à nobreza pela prestação de serviços à Coroa durante a guerra. [...] O que se passa nas peças, contudo, não é uma tentativa de reconstrução da história nem mesmo a reinterpretação dela. Ao contrário, é uma reimaginação teatral. No lugar da suposta estabilidade do fato, personagem, motivo, representados para convencer o público da verdadeira realidade do que eles assistem, há uma exibição de como a realidade é construída como teatro. ${ }^{17}$
\end{abstract}

Além disso, de acordo com o crítico irlandês, "o que interessa a Kilroy não é a realidade, mas a teatralização de vidas reais"18. Este é um ponto essencial na presente análise, visto que não se trata meramente da reconstituição dos registros biográficos no palco, mas da teatralização, da reimaginação teatral, enfim, da criação de um produto novo e diferente daquele que lhe serviu como base.

Abordando esse aspecto numa entrevista concedida a Thierry Dubost em março de 2004, Kilroy responde a uma questão referente à escolha de pessoas famosas como protagonistas de várias peças:

Sou fascinado por história. Acho que quando você é fascinado por história, você é fascinado pelas possibilidades de mudança na

\footnotetext{
17 "In the case of Double Cross this involved understanding for the hanged Nazi propagandist Lord Haw Haw, a perspective in which his motivations and actions could be seen as comparable to that of Brendan Bracken, raised to the peerage for his wartime services to the Crown. [...] What goes on in the plays, however, is not an attempted reconstruction of history or even a reinterpretation of it. It is instead a theatrical re-imagination. In place of the supposed stability of fact, character, motive, represented to convince audiences of the true reality of what they watch, there is a showing forth of how reality is constructed as theatre."

18 "What interests Kilroy is not their reality but the theatricalization of their real lives."
} 
história e de adulteração da história. Os dramaturgos que escrevem peças históricas adoram encontrar lacunas no registro. Eu sou estimulado imaginativamente por questões não respondidas na história, ou talvez por um elemento histórico, para torcê-lo, e ver o que poderia acontecer no processo. Portanto é menos uma questão de pessoas famosas do que tentar, por assim dizer, fornecer um registro imaginativo e uma competição com o registro real. ${ }^{19}$

Neste ponto, é necessário que se faça um paralelo entre o contexto e os elementos que influenciaram a composição e produção da peça e a teoria relacionada à adaptação ou apropriação da história/biografia.

Em Adaptation and Appropriation (2006), Julie Sanders analisa a apropriação da história. Segundo a autora, o termo genérico "ficção histórica" é muito amplo, o que a fez optar, em sua análise, por textos cujo autor apropriou conscientemente os fatos de um acontecimento particular ou de uma vida a fim de dar forma à ficção (p.139). Sanders afirma que os motivos pelos quais um autor faz tais escolhas podem variar e aponta duas razões: em alguns casos, há paralelos e comparações que evocam uma questão contemporânea; em outros, o autor deseja recuperar vozes perdidas ou reprimidas. Como exemplo da primeira situação, a autora cita a peça The Crucible (1953), em que Arthur Miller representa alguns fatos ocorridos durante a "caça às bruxas" em 1692 na colônia puritana de Salém, em New England, apresentando vários paralelos entre a história e o que estava ocorrendo nos Estados Unidos da década de 50, especificamente as perseguições empreendidas pelo Macartismo.

De acordo com Sanders, "a história não está sendo desfeita por meio das apropriações e adaptações, mas sua estabilidade está sendo

\footnotetext{
19 "I'm fascinated by history. I think that when you are fascinated by history, you are fascinated by the possibilities of changes in history and of tampering with history. Playwrights who write historical plays love to find gaps in the record. I'm stimulated imaginatively by unanswered questions in history, or maybe taking a historical thing and twisting it, and seeing what could happen in the process. So it's less a matter of famous people than of trying to, as it were, provide an imaginative record and competition with the actual record." (2007, p.138)
} 
questionada"20; a autora cita, ainda, um trecho de A Poetics of Postmodernism: History, Theory, Fiction, em que Linda Hutcheon observa: "O Pós-Modernismo não nega [a história] [...] apenas questiona como podemos conhecer hoje os acontecimentos reais do passado, a não ser por meio de seus vestígios, seus textos, os fatos que nós construímos e a que damos significado." ${ }^{21}$ Ou seja, a "História" é a interpretação de alguns autores e não o fato histórico em si, são vestígios do fato. Sanders conclui afirmando que a disciplina da história é, na verdade, uma série de histórias "contadas por contadores específicos de acordo com ideologias e contextos específicos" ${ }^{22}$.

Dessa forma, podemos dizer que, em Double Cross, Kilroy apropria-se dos registros históricos e das biografias de Bracken e Joyce a fim de questionar a estabilidade dos fatos transcorridos ("humanizando", por exemplo, o nazista Joyce), e de estabelecer paralelos e comparações com uma questão presente na Irlanda dos anos 80: o debate sobre a identidade nacional e os aspectos negativos do nacionalismo exacerbado.

Transferindo o foco para o texto em si, o título Double Cross representa o duplo e o cruzamento de fronteiras entre os países e ideologias, além de ser uma referência a um sistema utilizado durante a II Guerra, operado pelo XXCommittee. Segundo lan Dear (1995), este foi um comitê estabelecido pela Inteligência Militar Britânica em setembro de 1940 para coordenar a disseminação de informação falsa. Em janeiro de 1941, passou a operar o que ficou conhecido como Sistema Double Cross, cujo objetivo era controlar o

\footnotetext{
20 "History is not being undone by means of these appropriations and adaptations, but its stability is being questioned."(2006, p.143)

21 "Postmodernism does not deny [history] [...] it merely questions how we can know past real events, today, except through their traces, their texts, the facts we construct and to which we grant meaning." (1988, p.225)

22 "[...] told by particular tellers according to particular ideologies and contexts." (2006, p.146)
} 
sistema alemão de espionagem no Reino Unido, capturar os espiões e conhecer seus métodos e códigos. Esse sistema visava "obter informação sobre os planos e intenções dos alemães a partir das questões formuladas, influenciar os planos alemães pelas respostas dadas a essas perguntas, e, finalmente, enganar os alemães sobre as intenções e planos britânicos". 23

Em Double Cross, as personagens falam sobre uma estratégia muito usada durante a Segunda Guerra: reinventar informações durante períodos de conflito. O trecho abaixo é uma clara alusão ao título:

\footnotetext{
ATRIZ - Se William Joyce estava reinventando a Inglaterra, a Inglaterra estava também reinventando William Joyce. [...] Outros estudiosos da Imaginação referem-se a isso como o Efeito Double Cross.

ATOR - Isso é endêmico em situações de conflito entre nações . [...] Não admira que o Sr. Bracken estivesse interessado.

ATRIZ - Como Ministro da Informação, que é -

ATOR - Informação sendo seu negócio, como era -

ATRIZ - E, portanto, informação errônea também, sem mencionar desinformação -

ATOR - Era como se um Ministro da Informação Errônea tivesse sido estabelecido para contrariar seu Ministro da Informação.

ATRIZ - Duplicação absoluta. ${ }^{24}$
}

Ironicamente, a mesma estratégia é usada pelos protagonistas para reinventarem suas histórias pessoais, como Brendan Bracken que, segundo a personagem Popsie, passa sua vida "constantemente escapando,

\footnotetext{
23 "[...] to obtain information about German plans and intentions from the questions asked by it; to influence German plans by the answers sent to these questions; and, finally, to deceive the Germans about British plans and intentions." (1995, p.1289)

24 "ACTRESS - If William Joyce was re-inventing England, England was also re-inventing William Joyce. [...] Other students of the Imagination refer to it as the Double Cross Effect.

ACTOR - It is endemic in situations of conflict between nations. [...] No wonder Mr Bracken was concerned.

ACTRESS - As Minister of Information, that is -

ACTOR - Information being his business, as it were -

ACTRESS - And therefore misinformation as well, not to mention disinformation -

ACTOR - It was as if a Ministry of Misinformation had been set up to counteract his Ministry of Information.
}

ACTRESS - Absolute duplication." (p. 62) 
constantemente evitando, constantemente inventando" ${ }^{25}$. O biógrafo Charles Edward Lysaght comenta, em Brendan Bracken, que o filho de Winston Churchill, Randolph Churchill, certa vez teria afirmado que Bracken era um dos maiores mentirosos porque "ele não se importava em ser descoberto". (1979, p.144)

Brendan Bracken e William Joyce tornam-se, na peça, espelhos refletindo a imagem um do outro e são interpretados pelo mesmo ator (Stephen Rea, na produção do Field Day). Double Cross é composta por duas partes com subtítulos (Part One - The Bracken Play: London, e Part Two - The Joyce Play: Berlin) que podem ser consideradas, de fato, duas peças que se complementam a ponto de tornar inviável a encenação de apenas uma delas. Ambas apresentam uma estrutura similar, também como num espelho: iniciam com uma fala longa do rival no rádio e no telão, respectivamente. Em seguida, um casal de narradores com roupas neutras relata aspectos da vida de ambos, apontando pontos em comum. Após esse momento de contextualização, há uma longa fala do protagonista (Bracken ao telefone e Joyce no rádio). $\mathrm{Na}$ sequência, há cenas referentes à vida amorosa: Bracken com a dama inglesa de classe alta Popsie, e Joyce com sua esposa Margaret e o anglófilo alemão Erich formando um triângulo amoroso. Posteriormente, temos diálogos entre Lord Beaverbrook e o protagonista. Ao final, Bracken lê uma carta à sua querida mãe e Joyce, à sua amada esposa Margaret.

Outro aspecto interessante, em que observamos o poder de sugestão da linguagem teatral de Kilroy, é o fato de estarem em cena onze personagens, porém, segundo rubricas do autor, estes deveriam ser interpretados por apenas

25 "You spend your life constantly evading, constantly avoiding, constantly inventing." (p.33) 
três atores: um deles interpretaria os dois protagonistas; outro ator deveria fazer as personagens masculinas restantes, da mesma forma que a atriz, as personagens femininas. Ou seja, a teatralização, e não o realismo, é um ponto fundamental na obra.

O espectador ou leitor pode se questionar por que Kilroy escolheu Bracken e Joyce, dentre tantas figuras importantes durante a Segunda Guerra Mundial. A peça responde a essa pergunta claramente, pois ambos apresentam muitos pontos em comum, tais como: são homens de origem irlandesa que negaram seu passado, "reinventando" suas vidas e acabaram em lados opostos. Ambos trabalharam com a informação e a propaganda durante a guerra: Bracken era o Ministro da Informação britânico e Joyce, propagandista nazista, braço direito do Ministro da Propaganda alemão Joseph Goebbels. Além disso, Kilroy abordou a turbulenta vida amorosa de ambos, salientando as excentricidades de Bracken em seu caso com Popsie, e a relação de amor e ódio entre William Joyce e a esposa Margaret. Ironicamente, Bracken teve um câncer de garganta que foi diagnosticado em 1958, ano de sua morte; Joyce foi condenado por traição pela Justiça Britânica e enforcado em 1946, ou seja, ambos foram emudecidos antes de morrer.

$\mathrm{Na}$ introdução, o dramaturgo esclarece vários aspectos referentes à suas escolhas e razões pelas quais escreveu a obra. A conexão entre eles é que ambos criaram vidas alternativas porque a herança que Ihes foi legada no nascimento, a origem irlandesa, era intolerável. $\mathrm{O}$ autor afirma que queria escrever uma peça sobre nacionalismo e que Double Cross nasceu do debate sobre identidade nacional que o Field Day promoveu nos anos oitenta; comenta ainda que o que the interessou não foi o nacionalismo como uma fonte de 
autoaperfeiçoamento e avanço dos direitos civis, mas o nacionalismo como um fardo sombrio, uma fonte de trauma e debilitação: "Era inevitável, então, suponho, que eu acabasse escrevendo sobre um fascista"26, constatou Thomas Kilroy.

Há muitas referências a essa "herança intolerável" na peça. Em vários momentos, a origem de ambos é motivo de ofensa e acusação entre os protagonistas, tais como: JOYCE - "Ele é o filho de um pedreiro de Tipperary que também era um terrorista"27; ou BRACKEN - "Desde que o lugar em que nasci decidiu romper sua conexão com a Coroa à força, nunca mais desejei estar associado a ele."28; ou ainda, BRACKEN - "Meu pai tinha o rosto de um povo condenado."29

Ao longo de Double Cross, um protagonista confronta constantemente seu odiado duplo, revelando que são inimigos íntimos. Essa duplicação permite a Kilroy desenvolver uma psicologia de suas características compartilhadas. Há, em ambos os casos, uma memória de fatos ocorridos na infância, o que ajuda a definir a personalidade de cada um.

Uma cena que exemplifica e justifica essa rejeição à identidade irlandesa é o momento no qual Brendan Bracken, ao relembrar sua infância, tem um momento de confusão mental e começa a falar como seu pai:

BRACKEN (sotaque irlandês, como antes) Venha aqui, Peter, meu filho. Venha aqui um minuto, meu homenzinho. Você vai lutar pela Irlanda, não vai, garoto, quando você crescer, não como aquele seu

\footnotetext{
26 "What interested me was not so much nationalism as a source of self-improvement and the advancement of civil rights but nationalism as a dark burden, a source of trauma and debilitation. It was inevitable, then, I suppose, that I should end up writing about a fascist." (1994, pp. 12-13)

27 "JOYCE - He's the son of a Tipperary stonemason who was also a dynamite terrorist." (p.23)

28 "BRACKEN - Since the place in which I was born chose to break its connection with the Crown by force, I never wish to be associated with it." (p.44)

29 "BRACKEN - My father had the face of a condemned people." (p.45)
} 
irmão, Brendan-Brendy, o pequeno escoteiro, o filhinho da mamãe, sempre lamentando e chorando, quatro-olhos - (sotaque inglês) Me deixe sozinho! Me deixe sozinho! ${ }^{30}$

Nesse trecho, Kilroy sugere que, por trás de toda a negação e invenção elaborada por Bracken ao longo de sua vida, há um relacionamento conflituoso com o pai, ativista extremo pela causa irlandesa. No entanto, pode-se constatar que essa relação foi criada pelo autor, pois, segundo o biógrafo Lysaght, quando Joseph Kevin Bracken morreu o filho tinha apenas três anos de idade e não há registros sobre a relação de ambos ou da opinião do filho sobre o pai. (1979, p.27) Observa-se, portanto, que Kilroy explora essa lacuna biográfica acrescentando o conflito entre pai e filho, característica recorrente em suas personagens, inclusive em The Secret Fall of Constance Wilde e My Scandalous Life.

Não podemos nos esquecer de um aspecto muito importante no teatro de Thomas Kilroy: a cenografia, geralmente complexa e com uma forte simbologia. A rubrica inicial descreve detalhadamente o cenário, que além de conter um retrato de Edmund Burke acima da lareira, também apresenta, na primeira parte da peça, as figuras de Churchill, Rei George VI e Sir Oswald Mosley. Já na segunda parte, as figuras são invertidas, tornando-se Dr. Goebbels, Hitler e, novamente, Mosley.

O retrato do filósofo e político anglo-irlandês Edmund Burke (1729-1797) era, de fato, um objeto de decoração da casa de Bracken que, segundo Lysaght, era seu bem mais precioso (1979, p.82) e foi roubado pelo irmão

\footnotetext{
30 "BRACKEN (Irish accent, as before) Come here, Peter, me son. Come here a minnit, me little man. You'll stand up for Ireland, won't you, boy, when you grow up, not like that brother of yours in the corner, Brendan-Brendy, the little scut, Mammy's pet, always whinging and bawling, foureyes - (English accent) Leave me alone! Leave me alone!" (p.51)
} 
Peter a fim de chantageá-lo ${ }^{31}$. Entretanto, o que pretendia Kilroy ao recuperar esse elemento no cenário da primeira parte - The Bracken Play? Talvez quisesse sugerir uma identificação entre o conservador Burke e Brendan Bracken, que era Membro do Parlamento Inglês e pertencia ao Partido Conservador. Provavelmente, esta foi uma forma de ratificar a postura conservadora do Ministro da Informação. Edmund Burke era um teórico do conservadorismo e defendia o crescimento orgânico da sociedade, ao invés de reformas violentas. Suas reflexões sobre a ideologia revolucionária não só orientaram de maneira decisiva a opinião pública da Inglaterra contra a reestruturação política francesa, como passaram a constituir, para o homem inglês, o senso comum da validade da hierarquia. Sua principal obra como teórico político é a crítica que formulou à ideologia da Revolução Francesa, manifesta em Reflexões sobre a revolução na França e sobre o comportamento de certas comunidades em Londres relativo a esse acontecimento (1790), que foi traduzida para várias línguas e tornou-se o modelo das atitudes contrarrevolucionárias na Inglaterra e outros países da Europa.

Em relação às personagens históricas invocadas no cenário, algumas observações são necessárias. Sir Winston Churchill, Primeiro-Ministro britânico durante a guerra, confiou a Brendan Bracken o Ministério da Informação e muitos pensavam que Churchill era pai de Bracken devido à proximidade entre eles. Nas memórias do Primeiro-Ministro sobre a Segunda Guerra encontramse alguns trechos que sugerem esse relacionamento próximo. Churchill relata que tinha recebido telegramas de Washington sobre Harry Hopkins,

\footnotetext{
31 "He broke into the house in North Street, made away with Romney's portrait of Edmund Burke, and sent Brendan a note: 'Unless you give me eight thousand pounds, I shall sell this picture." (1979, p.96)
} 
"declarando que ele era o confidente e agente pessoal mais próximo do presidente dos Estados Unidos. Assim, providenciei para que fosse recebido pelo Sr. Brendan Bracken em sua chegada." (1995, p.461) Este trecho sugere que o Primeiro Ministro providenciou, segundo costume diplomático, a recepção de Hopkins feita pela pessoa também mais próxima do governo britânico, o agente pessoal e confidente de Churchill.

Lord Beaverbrook, proprietário da Express Newspapers e personagem importante da peça, também era muito próximo de Churchill, fato comprovado pelas memórias do Primeiro Ministro:

\footnotetext{
Durante essas semanas de lutas intensas e de ansiedade ininterrupta, Lord Beaverbrook, prestou serviços notáveis. [...] Seu ânimo e vigor pessoais eram tonificantes. Alegrou-me, em algumas ocasiões, poder apoiar-me nele. Ele não decepcionou. Sua força e talento pessoais, combinados com muita persuasão e engenhosidade, afastaram inúmeros obstáculos. [...] Senti a tal ponto o valor de Beaverbrook que, em 2 de agosto, com a aprovação do rei, convidei-o a participar do Conselho de Guerra. (1995, p.409)
}

Na Alemanha, Joseph Goebbels (1897-1945), Ministro da Propaganda, desenvolveu a propaganda radiofônica nazista, utilizando, inclusive, propagandistas americanos, britânicos e indianos. Além de incentivar o nazismo, sua propaganda distorcia os eventos da guerra, causando boatos e desencontro de informações, a fim de enganar os inimigos do Eixo. William Joyce, também conhecido como Lord Haw Haw, era propagandista britânico a serviço de Goebbels.

Um dos pontos de convergência entre os antagonistas é Sir Oswald Mosley, líder dos fascistas ingleses. Joyce se tornou membro da British Union of Fascists em 1933 e, graças ao seu poder de oratória, logo foi promovido a 
diretor de propaganda do partido. Porém Mosley, durante a guerra, acusou Joyce de traidor devido à sua propaganda nazista.

A princípio, associamos Joyce apenas às imperdoáveis práticas nazistas, dificultando qualquer identificação do espectador com o propagandista. No entanto, ao longo da peça, essa visão maniqueísta se perde devido ao tratamento dado pelo dramaturgo; para ele, não se trata de uma luta do Bem contra o Mal, de verdades absolutas, mas de seres humanos com crenças e conflitos. Kilroy, em entrevista concedida a Thierry Dubost em 2001, afirma que "a moralidade estereotipada é totalmente inadequada para explicar o comportamento humano"32.

Outro elemento importante no cenário é o telão que, além de possibilitar a presença de ambos no palco, visto que são interpretados pelo mesmo ator, também é uma alusão à grande importância do cinema para a propaganda de guerra, principalmente para a propaganda nazista. Aliás, Joseph Goebbels é considerado o pai do cinema nazista.

Além dos recursos visuais como flashes de luz, são utilizados vários recursos sonoros para produzir efeito de guerra. O som das bombas e sirenes anunciando ataques aéreos convida o espectador a uma jornada ao horror da Segunda Guerra Mundial. O rádio também é um recurso fundamental em cenas em que são ouvidas vozes, trechos de músicas da época e, principalmente, os discursos de William Joyce em seu programa "Germany Calling”.

Como foi observado na Introdução, Double Cross apresenta vários traços épicos; no entanto, antes de abordá-los, é necessário que partamos das

\footnotetext{
32 “[...] stereotypical morality is totally inadequate to account for human behavior.” (2007, p.127)
} 
características do drama puro aristotélico apontadas por Peter Szondi, em Teoria do Drama Moderno (2001).

O drama, segundo Szondi, é absoluto, "para ser relação pura, isto é, dramática, ele deve estar desligado de tudo o que lhe é externo" (p.30); o drama é primário, "não é representação (secundária) de algo (primário) [...] essa é uma das razões pelas quais a peça histórica sempre resulta 'nãodramática'. A tentativa de levar 'Lutero, o reformador' aos palcos implica a referência à história" (p.32); o dramaturgo está ausente no drama, “a fala dramática não é expressão do autor, tampouco é uma alocução dirigida ao público" (p.31); há o domínio absoluto do diálogo, que é o suporte do drama, visto que "da possibilidade do diálogo depende a possibilidade do drama" (p.34); e, por fim, Szondi afirma que

\begin{abstract}
O decurso temporal do drama é uma sequência de presentes absolutos [...] A descontinuidade temporal das cenas vai contra 0 princípio da sequência de presentes absolutos, uma vez que toda cena possuiria sua pré-história e sua continuação (passado e futuro) fora da representação [...] somente quando, na sequência, cada cena produz a próxima é que não se torna implícita a presença do montador. A frase (pronunciada ou não) 'deixemos passar agora três anos' pressupõe o eu-épico. (p.33)
\end{abstract}

Double Cross, assim como as outras peças abordadas nesta pesquisa, baseiam-se em biografias, ou seja, são representações secundárias de algo, portanto são não-dramáticas ou épicas. Além dos próprios narradores, outras personagens dirigem-se ao público para narrar ou comentar algo. Segundo Rosenfeld, "a direção ao público é sintoma de tendência épica, por não ser propriamente o personagem que se dirige ao público, mas o ator como portavoz do autor." (2006, p.56) 
A peça apresenta uma descontinuidade temporal, por meio do retorno a tempos passados e de comentários antecipando eventos futuros, quebrando a atualidade cênica, visto que toda a ação já aconteceu. Podemos citar também a transformação da personagem Brendan Bracken em William Joyce, realizada no palco durante a transição entre as duas partes da peça, suspendendo qualquer ilusão cênica.

Apontamos ainda como recursos épicos o telão, que torna possível os embates entre Bracken e Joyce, os cartazes com figuras históricas, a bandeira britânica e as flâmulas do Partido Conservador. Para Rosenfeld, "o uso de recursos cinematográficos no contexto cênico tem, sem dúvida, função epicizante, [...] acrescenta o horizonte de um narrador, o que relativiza a ação cênica." (2006, p.121). Os cartazes com figuras históricas, como Churchill ou Goebells, guardam estreita relação com o Teatro Épico de Brecht, visto que não pertencem diretamente à ação da peça, provocando um estranhamento e uma reflexão.

Duas falas de Bracken nas cenas iniciais ilustram bem a ação do ator épico, que "narra" seu papel, mantendo certa distância dele, que dialoga não só com seus companheiros cênicos, mas também com o público: "Na verdade, eu morri de câncer (indicando a garganta) Mais ou menos aqui. Se você colocasse sua mão aqui, você sentiria" ${ }^{33}$ e "Esse sujeito, Joyce. Nunca conheci o cara. Eu quero deixar isso perfeitamente claro, porque você vai ouvir uma versão diferente mais tarde" ${ }^{34}$.

\footnotetext{
33 "Actually, I died of cancer. (Indicating throat) Somewhere about here. If you were to put your hand here, you would feel." (p.24)

34 "This fellow Joyce. Never met the chap. I want to make that perfectly clear, because you will hear otherwise later on."(p.25)
} 
No início das duas partes, dois narradores, que não participam da ação, criam um efeito de distanciamento. Os narradores comentam sobre alguns aspectos biográficos que os protagonistas têm em comum. Tal contextualização faz-se necessária para que o espectador compreenda a presença de ambos na mesma peça:

ATOR (Narrador) - Senhoras e senhores, esta é a história de dois homens que inventaram a si mesmos.

ATRIZ - Ambos saíram da Irlanda nos anos vinte.

ATOR - No momento preciso em que a Irlanda declarou sua independência da Inglaterra.

ATRIZ - Na Inglaterra, ambos eliminaram todas as evidências de sua identidade irlandesa. Fabricando, em vez disso, identidades ultrainglesas para eles mesmos.

ATOR - Quando as bombas começaram a cair sobre a Europa ocidental após 1939 Bracken estava em Londres, ao lado de Churchill, Joyce estava em Berlim, no outro lado da cerca. ${ }^{35}$

Os narradores presentes em vários momentos enfatizam o caráter épico de Double Cross, visto que as explicações e questionamentos têm a função de provocar uma reflexão, causando, a princípio, um estranhamento e, posteriormente, a familiaridade. Anatol Rosenfeld, em O Teatro Épico (2006), afirma que:

\begin{abstract}
A teoria do distanciamento é, em si mesma, dialética. O tornar estranho, o anular da familiaridade da nossa situação habitual, a ponto de ela ficar estranha a nós mesmos, torna em nível mais elevado esta nossa situação mais conhecida e mais familiar. $O$ distanciamento passa então a ser negação da negação; leva através do choque do não-conhecer ao choque do conhecer. Trata-se de um acúmulo de incompreensibilidade até que surja a compreensão. Tornar estranho é, portanto, ao mesmo tempo tornar conhecido. (p.152)
\end{abstract}

\footnotetext{
35 "ACTOR (Narrator) - Ladies and gentlemen, this is the story of two men who invented themselves.

ACTRESS - Both men left Ireland in the twenties.

ACTOR - At the precise time when Ireland declared its independence of England.

ACTRESS - In England they both obliterated all evidence of their Irishness. Fabricating, instead, ultra- English identities for themselves.

ACTOR -When the bombs began to fall over Western Europe after 1939 Bracken was in London, by Churchill's side, Joyce was in Berlin, on the other side of the fence. (p.24)
} 
Quando os narradores utilizam os termos "story" e "invented" para narrar a história dos dois irlandeses, percebe-se a intenção do autor de reafirmar o caráter ficcional das cenas que virão, tais como os diálogos entre Bracken e Popsie, ou entre Margaret e Eric, entre outros elementos.

Fato é que Bracken nunca se casou nem teve relacionamentos estáveis, porém teve vários casos com damas da alta sociedade nas décadas de 30 e 40. Presume-se que a personagem Popsie, apesar de ser uma interessante criação de autor, seja uma alusão à Penelope Dudley Ward, afilhada de Churchill, ou a Lady Pamela Smith, filha do Conde de Birkenhead, visto que ambas são citadas brevemente nos registros biográficos.

O relacionamento entre Bracken e Popsie sugere que ele tinha gostos e preferências sexuais exóticas, ou até mesmo bissexuais. Percebe-se tal sugestão no momento em que Popsie entra em cena vestida como escoteiro. Entretanto, o dramaturgo afirma na introdução à peça que recebeu cartas oferecendo-Ihe detalhes dos gostos sexuais de Bracken e que estes eram mais pervertidos do que qualquer cena da peça. O autor conclui que "este é o velho problema de tentar ficcionalizar figuras históricas. Há sempre o perigo de ser incapaz de competir com a extravagância dos originais." ${ }^{36}$ De acordo com o biógrafo Charles Edward Lysaght, havia boatos de que Bracken era homossexual e, certa vez, ele fora visto com uma roupa de escoteiro numa festa homossexual na Escócia. (1979, p.147)

Kilroy mostra também o episódio em que o jornal The Evening Standard, de Lord Beaverbrook, publicou uma história ocorrida há mais de quarenta anos

\footnotetext{
36 "It's the old problem of trying to fictionalize historical figures. There is always the danger of being unable to compete with the outrageousness of the originals." (KILROY, 1994, p.15).
} 
na Irlanda, quando foi negada ao pai de Bracken uma licença para portar arma por ser considerado um nacionalista perigoso. A principal discrepância entre a biografia e a peça reside na postura de Beaverbrook, visto que, no palco, temos uma personagem que demonstra frieza ao justificar a publicação, priorizando suas descobertas jornalísticas ("Eu sou jornalista, Brendan. Sou um caçador de histórias." $\left.{ }^{37}\right)$. Em contrapartida, observamos, nos registros biográficos e nas cartas, que havia uma forte amizade entre eles e, neste episódio, Beaverbrook alegou desconhecimento em relação à publicação. De acordo com o historiador e biógrafo A. J. P. Taylor, em Beaverbrook (1972),

\begin{abstract}
O amigo mais próximo de Beaverbrook nessa época era Brendan Bracken cujas cartas eram tão divertidas quanto as do próprio Beaverbrook. [...] Mesmo assim, Beaverbrook não resistiu à tentação de fazer uma brincadeira com seu amigo. Em julho de 1944, The Evening Standard revelou que há quarenta anos foi negada ao pai de Bracken uma licença para portar arma na Irlanda, por ser considerado um perigoso nacionalista. Beaverbrook alegou desconhecimento da história [...] No entanto, ele não ficou satisfeito quando Bracken usou seu poder como Ministro da Informação e tentou abafar a história. ${ }^{38}$
\end{abstract}

O encerramento da peça de Bracken dá-se com uma transformação. Como já foi comentado, o ator narrador inverte a figuras do Rei George VI, Churchill e, inclusive, o quadro do filósofo conservador Edmund Burke. Temos agora as figuras de Hitler, Goebbels e novamente Mosley. Enquanto isso, a atriz, vestida com o mesmo sobretudo que usou como narradora, transforma Bracken na outra face do espelho: William Joyce. Dessa forma, Joyce, expondo

\footnotetext{
37 "I'm a journalist, Brendan. I chase stories." (p.42)

38 "Beaverbrook's closest intimate at this time was Brendan Bracken whose letters were as entertaining as those of Beaverbrook himself. [...] Even so Beaverbrook was not above playing a prank on his friend. In July 1944, The Evening Standard revealed that forty years before Bracken's father had been refused a gun license in Ireland as a dangerous Nationalist. Beaverbrook professed ignorance of the story [...]. He was not however pleased when Bracken used his power as Minister of Information and attempted to have the story suppressed." (p.551)
} 
sua impressionante cicatriz no rosto, encerra a primeira parte com um discurso antissemita.

$\mathrm{Na}$ segunda parte da peça, The Joyce Play: Berlin, o casal de narradores reaparece, assim como fizeram na primeira parte, para explicar e refletir sobre alguns registros biográficos:

\begin{abstract}
ATRIZ - E, então, nossa cena muda para Berlim -
ATOR - Para o Rundfunkhaus, o centro radiofônico do Dr. Goebbels, o mestre propagandista do Reich Nazista [...] No centro da mais extraordinária fábrica de vozes já reunidas na história do rádio. [...] Nosso irlandês transposto, nascido no Brooklyn, Nova York, mas criado no oeste da Irlanda.

ATRIZ - Depois de um curto período como um ultra-inglês na Inglaterra ele acabou como um cidadão alemão naturalizado do Terceiro Reich.

ATOR - Resumindo: Ele era americano mas também irlandês. Ele queria ser inglês, mas teve que se contentar em ser alemão. [...] Pelo corredor no Rundfunkhaus, estavam as outras estações de radiodifusão do Dr. Goebbels. Havia o Serviço de Radiodifusão Indiano, com indianos reais, o árabe, o escandinavo, o irlandês, o eslavo, a Torre de Babel multiplicadora do Dr. Goebbels. ${ }^{39}$
\end{abstract}

Observa-se, portanto, que muitas informações apropriadas e transpostas das biografias não são encenadas, mas apenas citadas e comentadas pelos narradores e personagens Bracken, Joyce, Lord Castlerosse e a jornalista que informa ao público nomes e detalhes sobre a prisão, julgamento e morte de Joyce.

Kilroy optou pela encenação dos aspectos que não constavam em detalhes nas biografias, as chamadas lacunas (termo utilizado pelo próprio

39 "ACTRESS - And, so, our scene shifts to Berlin -

ACTOR - To the Rundfunkhaus, the radio centre of Dr. Goebbels, the master propagandist of the Nazi Reich [...] At the centre of the most extraordinary factory of voices ever assembled in the history of radio. [...] Our transposed Irishman, born in Brooklyn, New York City, but raised in the West of Ireland.

ACTRESS - After a short period as an ultra-Englishman in England he ended up a naturalized German citizen of the Third Reich.

ACTOR - To summarize: He was American but also Irish. He wanted to be English but had to settle on being German. [...] Down the corridor from him in the Rundfunkhaus were the other broadcasting stations of Dr. Goebbels. There was the Indian Broadcasting Service, with real Indians, the Arab, the Scandinavian, the Irish, the Slav, the multiplying Tower of Babel of Dr. Goebbels." (p.60) 
dramaturgo), tais como a vida amorosa de ambos. Aliás, esta foi uma forma de humanizar as personagens por meio de conflitos e frustrações amorosas. Por exemplo, o turbulento relacionamento com a segunda esposa Margaret, o divórcio devido à infidelidade da mesma e o "re-casamento" são fatos constantes nas várias biografias sobre Joyce; entretanto, há lacunas nos relatos, ou seja, faltam detalhes. Fascinado pelas lacunas e pelas possibilidades de mudar a história, Kilroy as preencheu com intensos diálogos entre Joyce e Margaret, que abordam temas como o casamento burguês, valores impostos pela sociedade, adultério e, até mesmo, a poesia do irlandês William Butler Yeats (1865-1939).

O biógrafo John Alfred Cole (1964) aponta como motivo do divórcio do casal um jovem chamado Nicky que constantemente convidava Margaret para jantar ou beber algo, até mesmo no apartamento dele, porém ela sempre o evitava. Todavia, diante da apatia do marido, que ocupava grande parte de seu tempo com discursos, cigarros e bebidas, a moça passou a encontrar-se com Nicky. O trecho abaixo relata o momento em que Margaret resolve contar a Joyce onde estava passando seus fins de tarde:

Ele ficou atônito e incrédulo. Ela teve que repetir o que tinha dito. Ele começou a falar de forma incoerente, mas estranhamente, não explodiu de raiva. Suavemente, tentando compreender, ele implorou a ela para ajudá-lo a entender o que tudo aquilo significava. A conversa durou a noite inteira, com as mesmas questões inúmeras vezes. $^{40}$

Apesar de transpor alguns detalhes desse episódio, tais como a revelação de Margaret, a discussão noite adentro e os questionamentos de

\footnotetext{
40 "He was astonished and incredulous. She had to repeat what she had said. He began to talk incoherently but, strangely enough, he did not explode in anger. Gently, trying to understand, he implored her to help him to grasp what it all meant. The talk went on all night, with the same questions coming up again and again." (COLE, 1964, p.187)
} 
Joyce, Kilroy, ironicamente, substitui Nicky por Erich, um anglófilo alemão que venera a poesia de Yeats, um dos maiores símbolos da nação rejeitada por Joyce. Inclusive, o jovem recita uma das estrofes mais famosas do célebre irlandês, do poema $O$ do not love too long $^{41}$ : "Bem-amada, não ames muito tempo:/ Por longo tempo dei o coração,/ E vim a me tornar fora de moda/ Como velha canção." ${ }^{42}$ Nas cenas finais, porém, há uma transformação considerável em Erich, que entra em cena com um uniforme nazista e declama algumas linhas de Fausto, do consagrado autor alemão Goethe: "Um olhar seu, uma palavra satisfaz mais do que toda a sabedoria deste mundo ${ }^{43}$, Margaret." $\mathrm{O}$ autor apresenta aqui outra oposição a partir de dois símbolos nacionais, Yeats e Goethe. Enfim, Erich é uma interessante invenção de Kilroy e mais um elemento nesta rede histórica de possibilidades irônicas.

No desfecho da peça, temos dois momentos importantes: a discussão filosófica entre Lord Beaverbrook, o magnata da indústria jornalística, e William Joyce, já na prisão após o julgamento por traição em Old Bailey (mesmo tribunal em que Oscar Wilde fora julgado em $1895^{44}$ ). Nessa cena, são abordados temas como traição e fidelidade, promovendo uma reflexão sobre a problemática apresentada pelo autor desde o início da peça. Temos, ainda, o último diálogo entre Joyce e Bracken, quando este aparece no telão: "Estou procurando meu irmão [...] Meu irmão tem o rosto de um povo condenado"45. $\mathrm{O}$ que não sabemos é se Bracken refere-se a Peter ou ao próprio Joyce, a outra

\footnotetext{
41 "Sweetheart, do not love too long I loved long and long, And grew to be out of fashion Like an old song." (p.67)

${ }^{42}$ Tradução de Péricles Eugênio da Silva Ramos.

43 "Ein Blick von dir, ein Wort mehr unterhalt, als alle Weisheit dieser Welt, Margaret." (p.77)

${ }^{44}$ Tal paralelo faz-se necessário, visto que a peça analisada no segundo capítulo baseia-se em biografias de Oscar e Constance Wilde: The Secret Fall of Constance Wilde.

45 "I am searching for my brother [...] My brother has the face of a condemned people" (p.89)
} 
face do espelho. Há, nesse momento, a retomada da expressão "povo condenado" referindo-se aos irlandeses e à já citada "herança intolerável" rejeitada por ambos os protagonistas.

Thomas Kilroy, no processo de composição de Double Cross, apropriouse de vários elementos biográficos dos protagonistas, incluindo passagens da infância, relacionamentos amorosos e intrigas durante a II Guerra Mundial. Porém, grande parte das informações transpostas das biografias, por clara escolha do autor, não são encenadas, mas apenas citadas e comentadas pelos narradores e alguns personagens, produzindo um efeito de distanciamento ao longo de toda a obra.

Além disso, Double Cross apresenta muitos elementos ficcionais (tais como o improvável encontro entre Joyce e Bracken ou o relacionamento de Bracken com Popsie, personagem criada por Kilroy), o que nos leva a concluir que se trata de uma apropriação de registros históricos, conforme a definição dada por Julie Sanders (2006), a fim de, neste caso, estabelecer paralelos com questões contemporâneas por meio da reformulação dos textos-fonte.

Foi verificado também que a peça apresenta várias características do teatro épico, tais como referências a elementos exteriores à peça (no caso, as próprias personagens históricas), suspensão da ilusão teatral, quebra da atualidade cênica, direcionamento ao público por parte dos narradores e demais personagens, a transformação da personagem em cena e recursos epicizantes, como o telão e os cartazes. 
As personagens ficcionais Brendan Bracken e William Joyce, apesar de corresponderem em vários aspectos às figuras históricas, tornam-se, em Double Cross, instrumentos de uma importante causa: promover um debate sobre o poder, a identidade e a criatividade, e criticar o nacionalismo exacerbado, tão comum na Irlanda, e o Fascismo, triste realidade na Europa durante as décadas de 30 e 40. 


\section{CAPÍTULO 2}

\section{THE SECRET FALL OF CONSTANCE WILDE: \\ "Marionetes do Destino"}

One uses research in playwriting in order to forget it! At a certain point the imagination takes over.

Em The Secret Fall of Constance Wilde (1997), Thomas Kilroy transpõe episódios da vida de Constance, esposa de uma das figuras mais polêmicas da literatura mundial, Oscar Wilde. Nessa peça, além de assistirmos à trágica queda (física, moral e financeira) da protagonista, numa mistura de fatos e especulação, também acompanhamos a decadência pública e privada de Oscar, fruto de seu relacionamento com o amante Lord Alfred Douglas.

Da mesma forma que em Double Cross, veremos o desenvolvimento da peça e como o autor apropriou-se de registros biográficos para transpô-los para a linguagem teatral. A transposição em questão, como foi exposto no capítulo introdutório, é de um gênero que conta uma história (a biografia) para um que mostra uma história (o teatro). Retomando alguns conceitos, Linda Hutcheon (2006) explica que contar uma história significa descrever, explicar, resumir; por outro lado, mostrar uma história envolve uma representação visual. Segundo Hutcheon, a adaptação performática deve dramatizar, ou seja, a narração deve ser transcodificada em falas, ações, sons e imagens visuais. É 
justamente esse processo que será analisado no presente capítulo a fim de responder às seguintes questões: $O$ que Kilroy enfatizou, criou ou omitiu? Como? Quais recursos teatrais foram utilizados? Para quais efeitos?

É importante também retomar a questão da apropriação da história abordada por Julie Sanders em Adaptation and Appropriation (2006). Segundo a autora, uma das razões pelas quais um autor se apropria conscientemente de fatos de um acontecimento particular ou de uma vida a fim de dar forma à ficção é justamente o desejo de recuperar vozes perdidas ou reprimidas (p.139), de recontar a história de personagens marginalizadas reinventando suas vozes (p.142). Certamente, podemos considerar Constance Wilde uma voz reprimida e marginalizada, visto que geralmente é uma personagem secundária nas biografias e obras ficcionais que relatam a vida de Oscar Wilde, ao contrário do que ocorre em The Secret Fall.

O material biográfico sobre Oscar Wilde, Constance Wilde e Lord Alfred Douglas é muito amplo, pois eles foram polêmicos e tiveram vidas trágicas. Devido a isso, já foram tema de várias biografias, romances e peças. Segundo Munira H. Mutran,

O grande número de biografias de Oscar Wilde, das quais a mais comovente é a de seu filho, e a melhor, a de Richard Ellmann, demonstra que o interesse por detalhes da vida do escritor não diminuiu em mais de um século depois de sua morte. Já na década de 1880, a figura de Wilde aparecia em romances, paródias e sátiras. A mais famosa delas, Patience, de Gilbert e Sullivan, teve grande sucesso porque o público reconhecia nas personagens todos os maneirismos e ditos espirituosos de Wilde e seu grupo. Mais recentemente, o romance de Peter Ackroyd, The Last Testament of Oscar Wilde (1983), descreve os patéticos últimos dias do escritor em Paris, e a peça Saint Oscar, apresentada em Derry, Irlanda do Norte, em dezembro de 1989, escrita por Terry Eagleton, mostra uma personagem destilando desprezo por todas as formas de compromisso. (2002, p.21) 
Oscar Wilde: His Life and Confessions, escrita em 1916 por seu amigo e editor Frank Harris, foi uma das primeiras biografias sobre Wilde. Também seus amigos próximos Robert Sherard, Robert Ross, Charles Ricketts e, inclusive, o próprio Lord Alfred Douglas publicaram biografias e correspondência. Devido ao fato dos autores terem sido amigos de Wilde, os textos não foram escritos de forma imparcial, visto que foram influenciados pelo desejo de defesa ao amigo biografado.

The Life of Oscar Wilde (1946), escrita Hesketh Pearson, contém material derivado de conversas com muitos daqueles que conheceram e trabalharam com Wilde. Vyvyan Holland, seu filho mais novo, publicou suas memórias Son of Oscar Wilde (1954), que revela detalhes particulares da família e as dificuldades vividas por Constance e seus filhos após a prisão de Oscar. A obra, que foi revisada pelo filho de Vyvyan, Merlin Holland, e publicada novamente em 1989, emociona o leitor em vários momentos com o drama familiar relatado.

Richard Ellman, após detalhada pesquisa sobre o material existente, escreveu a biografia Oscar Wilde (1988), obra premiada postumamente nos Estados Unidos com o National Book Critics Circle Award em 1988 e Pulitzer Prize em 1989. Esta é considerada por muitos a biografia mais completa sobre o escritor irlandês. Além disso, foi a base para o filme Wilde (1997), dirigido por Brian Gilbert, com roteiro de Julian Mitchell, e Stephen Fry como Oscar, Jude Law como Lord Alfred Douglas e Vanessa Redgrave como Speranza, a mãe de Wilde.

Várias peças já foram escritas sobre este polêmico autor, tais como: Oscar Wilde: A Play (1937), de Leslie \& Sewell Stokes; St. Oscar (1989), de 
Terry Eagleton; The Judas Kiss (1997), de David Hare, com Liam Neeson como Wilde, e Gross Indecency: The Three Trials of Oscar Wilde (1998), de Moises Kaufman.

Uma das fontes mais importantes utilizadas por Kilroy na concepção de ambas as peças foi a carta De Profundis, que apresenta muitas características de Bosie e de seu relacionamento com Wilde. Sobre a carta, Munira H. Mutran escreveu:

De Profundis é uma carta de amor e ódio para Lord Alfred Douglas (Bosie) [...]. Personagens secundárias são construídas: os amigos, Lady Wilde, a esposa Constance, os filhos Cyril e Vyvyan, o detestável Marquês de Queensberry, pai de Bosie, Lady Queensberry, lacrimosa e pérfida. Bosie é o antagonista, o inimigo. [...] Não trata, pois, o primeiro movimento, das terríveis consequências de sua amizade com Bosie, mas da qualidade desse relacionamento, que 'enquanto durou foi intelectualmente degradante', uma relação estéril (que tanto poderia ser homossexual ou heterossexual) que destrói o parceiro e nesse caso adquire dimensão muito mais ampla. O tema dessa parte da peça, a culpa, é de três tipos: a culpa por permitir que uma amizade, 'ruína de sua arte', dominasse sua vida; a culpa por permitir que Bosie o levasse à ruína financeira; e, por último, a pior de todas, a da degradação em que mergulhou. (2000, pp.91-92)

As personagens e aspectos apontados no trecho acima estão presentes na peça de Kilroy, tais como Wilde e sua conflituosa relação com Bosie, a esposa Constance e seus filhos Vyvyan e Cyril, mostrando que existem relações intertextuais entre De Profundis e a peça analisada.

The Secret Fall of Constance Wilde estreou em Outubro de 1997 no Abbey Theatre, em Dublin; também foi encenada nos Estados Unidos em 2008, porém, na montagem americana, os Assistentes não usaram máscaras. Tal mudança prejudicou a montagem, visto que todos os elementos cênicos acrescentados por Kilroy têm uma função ou um intuito de causar determinados efeitos. No caso das máscaras, trata-se de uma alusão às 
máscaras sociais utilizadas por Constance e Oscar para ocultar aspectos condenados pela sociedade.

Em entrevista a Thierry Dubost em 2004, Patrick Mason, diretor da primeira montagem da peça (dedicada a ele ao ser publicada), comentou sobre o processo de composição da mesma, relatando que quando ele era o diretor artístico do Abbey, pediu para Kilroy escrever uma peça para o centenário da prisão de Wilde em Reading e perguntou se ele poderia ler O Retrato de Dorian Gray para adaptá-lo para o palco. Segundo o diretor,

\begin{abstract}
Ele disse que poderia, e que tinha algumas ideias sobre usar Dorian Gray para revelar o tipo de situação biográfica de Oscar, e Lord Alfred Douglas e Constance. Pesquisando, ele ficou mais e mais fascinado por Constance Wilde. Seis meses depois, ele me telefonou, e disse 'Eu acho que tenho alguma coisa sobre Constance. Posso deixar Dorian Gray de lado?' Eu disse, 'Claro que pode. Siga para onde quer que esteja sendo levado.' Este foi o início de The Secret Fall. ${ }^{46}$
\end{abstract}

O depoimento de Patrick Mason demonstra que, apesar de ter sido encomendada para o Centenário da Prisão de Wilde em Reading, a peça foi fruto de um profundo envolvimento do autor com o tema a partir de um complexo processo de pesquisa e que ele, realmente, ficou fascinado por Constance. Em email enviado ao autor em abril de 2010, perguntei-Ihe sobre as biografias e fontes utilizadas e sobre o processo de composição das peças. Em resposta, ele afirmou:

Prezada Adriana,

Sim, eu usei os livros de Cole, Lysaght, Taylor e West (Double Cross) e todas as biografias de Wilde assim como muitos outros livros sobre

\footnotetext{
46 "He said he would, and he had some idea about using Dorian Gray to reflect the sort of biographical situation of Oscar, Lord Alfred Douglas and Constance. In researching that, he got more and more fascinated by Constance Wilde. Six months afterwards, he telephoned me, and said 'I think I have got something about Constance. Can I forget about Dorian Gray?'. I said, 'Of course you can. Follow wherever it is going to lead you.' That was the beginning of The Secret Fall." (DUBOST, 2007, p.169)
} 
o período. Eu também usei as biografias de Constance Wilde de Joyce Bentley e Anne Clark Amor. As cartas de Wilde foram muito importantes devido ao meu interesse em sua voz autêntica. Passei um bom tempo lendo as cartas de Constance Wilde na Clark Memorial Library em Los Angeles. Esta foi uma experiência emocionante porque pude acompanhar sua deterioração física ao longo dos anos no declínio da qualidade de sua escrita. Mas, afinal, usamos a pesquisa na dramaturgia para esquecê-la! Num certo ponto a imaginação assume o controle. Eu acho que a pesquisa funciona então como um bloqueio para muitos erros inaceitáveis. Espero que este seja um início! Thomas ${ }^{47}$

O aspecto mais importante na resposta do autor foi a constatação de

que a pesquisa é fundamental numa peça baseada em biografias, porém num

determinado ponto o artista deve desvencilhar-se de todo o conteúdo

pesquisado para que este não se torne uma "camisa de força". Dessa forma, a

imaginação poderá dominar o processo, tornando a obra em composição uma

verdadeira obra de arte e não uma mera reprodução de fatos históricos. Essa

hipótese é confirmada numa entrevista concedida por Kilroy em 2001, quando,

ao Ihe ser perguntado sobre o valor histórico de sua peça, ele explica:

Se uma peça histórica é uma peça teatral, deve ser um trabalho de imaginação em vez de um trabalho de história, então você deve ter algum tipo de posse pessoal dela. Você deve encontrar uma espécie de modo pessoal. Senão, permanecerá uma reprodução de fatos históricos. Você deve - de algum modo - envolvê-la num nível muito personalizado. [...] Esta peça tenta subverter a história conhecida de Wilde. Parcialmente por apresentar a peça do ponto de vista de Constance, mas há também o fato de Constance ser deliberadamente uma invenção. Ou seja, ela não é a Constance histórica. Eu não acho que Wilde o seja, na peça, mas ele é mais próximo talvez do Wilde com quem estamos mais familiarizados. Mas ela é totalmente uma

\footnotetext{
47 “Dear Adriana,

Yes, I used the Cole, Lysaght, Taylor and West books (Double Cross) and all the Wilde biographies as well as many other books about the period. I also used the Joyce Bentley and Anne Clark Amor biographies of Constance Wilde. The Wilde letters were very important because of my interest in the speaking voice. I spent some time reading the letters of Constance Wilde in the Clark Memorial Library in Los Angeles. This was a moving experience because one could follow her physical deterioration over the years in the declining quality of her hand-writing. Having said that, one uses research in playwriting in order to forget it! At a certain point the imagination takes over. I think research works then as a block on your making too many unacceptable mistakes. Hope this is a start! Thomas"
} 
invenção de minha parte. Por isso, o valor histórico desta peça é bastante limitado. ${ }^{48}$

No trecho acima, o autor reafirma o valor literário e artístico de sua obra, pois apesar de transpor vários episódios da vida da Constance histórica para a Constance ficcional, ele explorou, sobretudo, as lacunas biográficas, tais como as discussões entre Constance e Oscar após a crise, os possíveis embates entre Douglas e Constance e, principalmente, as cenas com apelo erótico entre Oscar e Douglas.

O título da peça apresenta sentido ambíguo, pois, além de ser uma clara referência à queda sofrida por Constance na escadaria de sua House Beautiful em Tite Street 16 (que, para alguns, foi um trágico acidente e, para outros, uma tentativa de suicídio devido ao sofrimento), também se refere à decadência moral e financeira que se abateu sobre Mrs. Wilde após os escândalos e a prisão do marido. Além disso, a ambiguidade se apresenta no título ao relacionar a queda secreta de Constance à queda pública de Wilde.

A longa rubrica inicial, além de descrever o cenário e a ação das personagens, explica a função dos Assistentes e das Marionetes, que desempenham os papéis dos filhos de Wilde, Cyril e Vyvyan (vestindo pijamas ou roupinhas de marinheiro); de cavalheiros vitorianos, juiz, advogados, carcereiros, policial e, inclusive, o Pai de Constance, Horace Watson Lloyd, na polêmica cena sugerindo o estupro de Constance na infância.

\footnotetext{
48 "If a history play is to be a play, is to be a work of imagination rather than a work of history, then you have to have some kind of personal possession of that. You have to find some kind of personal way into it. Otherwise, it will remain as a wordy reproduction of historical fact. You have to - in some way - engage it at a very personalized level. [...] This play tries to subvert the known history of the Wilde story. Partly by taking the play from the point of view of Constance, but also the fact that Constance is very deliberately an invention. That is to say, she is not the historical Constance. I don't think the Wilde is, either, in the play, but he's closer perhaps to the Wilde that we would be familiar with. But she is quite distinctly an invention on my part. Therefore, the historical value of this play is pretty limited." (DUBOST, 2007, p.133)
} 
Os seis Assistentes (utilizando máscaras brancas, sem rosto, chapéucoco, trajes vitorianos, luvas brancas, "clappers") manipulam as Marionetes e são enfermeiros ou garçons, movimentam objetos de cena e peças do figurino e, principalmente, são Figuras do Destino (p.11) na primeira cena e Figuras da Morte (p.68) na última.

As rubricas descrevem vários elementos no cenário e recursos utilizados por Kilroy, tais como o círculo branco e as marionetes, que são fruto da influência do Teatro Oriental, especificamente o Bunraku, o teatro de marionetes japonês, e o Kabuki. Além disso, eles não estão ali apenas para causar determinados efeitos. Segundo o autor:

Com The Secret Fall of Constance Wilde, o uso de marionetes e o círculo branco no palco estavam lá desde o início. De modo que tive essa concepção da peça, que veio até certo ponto de meu interesse pelo teatro japonês clássico. O Bunraku, particularmente, em que fiquei fascinado pelo tipo de conjunção de imagens reais e marionetes. Isso também veio de Wilde e sua fascinação por marionetes, e com toda sua ideia do ator como sendo um tipo de marionete. Isso também teve a ver com os temas da peça, o fato de que eu estava lidando com três pessoas que foram até certo ponto marionetes do destino. Você sabe que eles foram manipulados por forças que eram na verdade maiores do que qualquer um deles. Então, é algo orgânico, em vez de apenas alcançar efeitos. ${ }^{49}$

Kilroy, em 2001, afirmou que seu interesse pelo teatro japonês começou

em 1994 num Congresso sobre Estudos Irlandeses no Japão, e se intensificou em viagem posterior, durante a qual esteve em contato com a cultura japonesa por três meses na Universidade de Kyoto. O Kabuki é o teatro tradicional

\footnotetext{
49 "With The Secret Fall of Constance Wilde, the whole use of puppets, and as it were, a white circle on stage, this was there from the very beginning. So that I had this conception of the play that came to some extent out of my interest in classical Japanese theatre. Bunraku, particularly, where I was fascinated by the kind of conjunction of so-called real images and puppet images. It also came out of Wilde, and Wilde's fascination with puppetry, and with his whole idea of the actor as being a kind of marionette. It also had to do with the thematic concerns of that play, the fact that I was dealing with three people who were to some extent puppets of fate. You know that they were manipulated by forces that were actually bigger than anyone of them. So, it's an organic thing, rather than reaching for effects." (DUBOST, 2007, p.138)
} 
popular do Japão e surgiu no século XVII. A diferença entre o Kabuki e o Bunraku está na forma, mas os temas se aproximam. Enquanto o Kabuki utiliza atores do sexo masculino, o Bunraku usa os bonecos para falar de conflitos morais nas relações humanas. O autor que, quando esteve no Japão, assistiu a muitas peças do teatro japonês clássico, afirma que, apesar da concepção de marionetes ter começado a partir do Bunraku, isso foi mudando conforme a peça ia se desenvolvendo. Também afirma que "estava tentando brincar com algumas técnicas do Kabuki, de transformação da personagem" ${ }^{50}$. Como exemplo da influência do Kabuki, podemos citar a ação dos Assistentes que auxiliam nas mudanças de figurino (incluindo roupas, perucas e acessórios) de Constance, Oscar e Douglas, sugerindo a passagem do tempo.

De acordo com Nicholas Grene (2002), no Bunraku, os atores que manipulam as marionetes não estão escondidos. Contudo, eles estão encapuzados (com exceção do mestre, que comanda a cabeça do boneco) e completamente vestidos de negro e, por convenção, são invisíveis para o público. Segundo Grene, Kilroy transformou seus manipuladores cênicos em algo totalmente diferente, visto que no Bunraku, o negro dos mestres marioneteiros os faz desaparecer; em contrapartida, os trajes dos assistentes de Kilroy atraem nossa atenção a eles ${ }^{51}$.

A influência do Bunraku e do Kabuki, certamente, intensificam a perspectiva épica da peça devido à suspensão da ilusão cênica. Segundo Rosenfeld, o "momento antiilusionista se acentua no Bunraku - que

\footnotetext{
50 "I also was trying to play around with some techniques of Kabuki, of transformation of character." (DUBOST, 2007, p.129)

51 "Kilroy, inspired by this visual effect in Bunraku, turns his onstage manipulators into something quite different, described in the opening stage direction of the play. Where the black of the Bunraku puppetmasters blanks them out, the costuming of Kilroy's attendant figures draws our attention to them."
} 
contaminou todo o teatro Kabuki - pelo fato de os exímios operadores dos bonecos - três para cada um - serem plenamente visíveis." (2006, p.110)

Geralmente, o teatro de Kilroy é classificado como não-realista, altamente estilizado; contudo, há alguns elementos realistas em The Secret Fall, como os beijos entre Oscar e Douglas, o comportamento de Oscar condicionado pela atração física e pelo instinto, as discussões sobre casamento e adultério entre Constance e Oscar, entre outros.

Ao contrário das cenas realistas, a primeira demonstra a natureza artificial e espetacular tão característica das peças de Kilroy. Quando dois Assistentes, representando as Figuras do Destino, conduzem Oscar e Constance, já no final de suas vidas, como se fossem verdadeiras marionetes, o desgaste físico e a fragilidade são visíveis, ou seja, não há máscaras de aparência. Essa cena sugere que os dois são, de fato, "Marionetes do Destino" e enfatiza a perspectiva épica da peça por meio da suspensão da ilusão cênica.

A peça é dividida em duas partes, antes e após a prisão de Wilde, e não apresenta subtítulos, ao contrário do que ocorre em Double Cross. Há diálogos tensos entre Oscar e Constance, Oscar e Douglas, e Constance e Douglas; no entanto, como as três personagens não aparecem juntas em nenhuma cena, surgiram questionamentos referentes à razão pela qual Kilroy não as colocou frente a frente. Uma possível hipótese é que o autor quisesse explorar a dupla personalidade de Oscar que, quando estava com Constance demonstrava profunda admiração e amor fraternal por ela; com Douglas, porém, expressava atração física e pouco interesse pelo sofrimento da esposa. Ele mudava seu discurso de acordo com a situação. Tal hipótese é confirmada na fala de 
Douglas "Longe dela você é totalmente diferente. Uma coisa no campo, outra coisa na cidade. [...] Duas caras" ${ }^{\prime 2}$. No diálogo abaixo, Douglas refere-se ao comportamento instável de Wilde, afirmando existirem muitos Oscars:

CONSTANCE - Eu conheço um Oscar que ninguém conhece!

DOUGLAS - Precisamente. Há muitos Oscars. Isto é o que o faz tão sedutor.

CONSTANCE - Mas eu falei com ele na prisão.

DOUGLAS - Prisão é uma coisa, liberdade é outra. ${ }^{53}$

$\mathrm{Na}$ primeira cena, alguns aspectos biográficos são citados durante a discussão entre Constance e Oscar, como as idades e as datas de nascimento de Cyril e Vyvyan, o pedido desesperado de Oscar para ver os filhos e a negativa de Constance a fim de protegê-los, a acusação e a pena cumprida por Oscar na prisão. Observa-se também a angústia de Constance que, vista por todos como a boa esposa que nunca gritava, deseja se afirmar e se autoconhecer. Segundo Ellmann, Constance falava pouco, e parecia quase muda ao lado do marido (1988, p.255). No entanto, Kilroy cria uma Constance que grita pelos seus direitos e expressa sua indignação diante de toda a traição sofrida. Nessa cena, Constance também fala sobre detalhes íntimos do casal, sobre sua queda e consequente paralisia. Ao final, ela pede a Oscar que a siga numa jornada secreta de volta ao passado para que ela possa compreender e encarar a si mesma, e não apenas aceitar os fatos com sua "incrível capacidade de aceitar" (p.44). Ou seja, há uma quebra da atualidade cênica, o que caracteriza um traço épico.

\footnotetext{
52 "Away from her you are utterly different. One thing in the country, another thing in town. [...] Double-faced." (p.32)

53 "CONSTANCE - I know an Oscar that no one else can know!

DOUGLAS - Precisely. There are many Oscars. That is what makes him so seductive. CONSTANCE - But I spoke to him in prison.

DOUGLAS - Prison is one thing, freedom is another." (p.59)
} 
Num dos momentos mais intensos da peça, o Andrógino entra em cena completamente nu e Oscar, em seu primeiro monólogo, o exalta, afirmando ser essa criatura a perfeição, comparando-o a várias obras de arte que, além de simbolizarem a beleza, também representam seres andróginos:

\begin{abstract}
OSCAR - (gritando) Preciso possuí-lo! Eu o possuirei! Nem homem nem mulher mas ambos. Dionísio, o homem-mulher como Ésquilo o chamou, desceu como um garoto dourado vestido de branco em uma sala de visitas em Londres. A grande ferida da Natureza, a ferida do gênero, foi curada. E o ovo dividido de Platão unido mais uma vez em uma única, perfeita esfera. Hermafroditus nascido de um beijo na clara primavera de Salmacis, próxima a Helicarnassus. [...] Este é o sonho de João Batista de Leonardo, dos sonetos de Shakespeare, de Séraphita de Balzac! E por quê? Por quê? Por quê, porque este é o sonho do Paraíso restaurado, o Adão não-dividido, inteiro e intacto, onde não há homem, não há mulher, não há dualidade, não há contrário, não há mãos desajeitadas e grotescas sobre o Outro porque o Outro reside em si mesmo. Mas nossa época aterrorizada não pode suportar tal visão. ${ }^{54}$
\end{abstract}

Os escândalos vividos por Wilde trouxeram à tona o tema da Moralidade e Kilroy leva essa discussão para o palco, por exemplo, quando Douglas afirma que as distinções entre preto/branco, Bem/Mal, masculino/feminino não deveriam existir. O Andrógino representa, justamente, a quebra dessa dualidade. Porém, segundo a personagem, os seres humanos não conseguiriam suportar essa confusão e, por isso, inventaram a Moralidade para manter cada um e cada coisa em seu lugar. De acordo com Kilroy, ele tentou colocar duas visões diferentes de mundo, uma representada por Constance e outra representada pela "frivolidade gay wildeana" e todo o universo de

\footnotetext{
54 "OSCAR - (a great yell) I must have it! I will have it! Neither man nor woman but both. Dionysus, the manwoman as Aeschylus called it, descended as a golden boy in whites into a London drawing room. The great wound in Nature, the wound of gender, was healed. And Plato's divided egg united once more in a single, perfect sphere. Hermaphroditus born of a kiss in the clear spring of Salmacis, near Helicarnassus. [...] It is the dream of Leonardo's Baptist, of Shakespeare's sonnets, of Balzac's Séraphita! And why? Why? Why, because it is the dream of Paradise restored, the undivided Adam, whole and intact, where there is no man, no woman, no duality, no contrary, no grotesque fumbling towards the Other because the Other resides within oneself. But our frightened time cannot bear such a vision." (p.20)
} 
Douglas e Wilde: "O ponto de vista de Constance demanda uma moralidade visível, um sistema coerente de moralidade. A visão de Wilde [...] tem que explorar a vida em todas suas dimensões, e fora disso atingir algum grau de sentido" ${ }^{" 55}$. Para o autor, ambos são modos de tentar encontrar sentido e nenhum deles é imposto como um modelo. Ao contrário, o único modelo oferecido é o conflito entre os dois lados.

É fato comprovado que Oscar teve inúmeras relações extraconjugais, desde breves encontros com rapazes de classe baixa, os "rent boys" (p.15), até casos que se estenderam por anos, como o relacionamento com Lord Alfred Douglas. De forma irônica, Douglas sugere a Constance que ela não é a única Mrs. Wilde:

DOUGLAS - Nada, Sra. Wilde. Sra. Wilde - Sra. Wilde. Eu ouvi este nome sendo usado por outros, Sra. Wilde. (Novamente a risada, novamente interrompida) CONSTANCE - Que outros?

DOUGLAS - Bem, se você quer saber, um jovem chamado Edward Shelley. Só para citar um. ${ }^{56}$

Ellmann cita uma lista utilizada no julgamento de Wilde, na qual havia mais de doze rapazes envolvidos. O primeiro da lista era justamente Edward Shelley e seus encontros foram de fevereiro até maio de 1892 (1988, p.443).

Além da protagonista Constance Wilde, da qual trataremos adiante, há outras mulheres citadas na peça, tais como a mãe e as irmãs de Wilde, admiradas e idealizadas por ele. Em vários momentos, Kilroy ressalta a

\footnotetext{
55 "The Constance point of view would be one which would demand a visible morality, a coherent system of morality. The Wilde view [...] has to explore life in all its dimensions, and out of that achieve some degree of meaning." (DUBOST, 2007, p.132)

56 "DOUGLAS - Nothing, Mrs Wilde. Mrs Wilde - Mrs Wilde. I have heard that soubriquet used of others, Mrs Wilde. (Again the laugh, again cut short) CONSTANCE - What others?

DOUGLAS - Well, if you must know, a young man named Edward Shelley. For one." (p.29)
} 
importância de Speranza, ou Lady Wilde. Alguns biógrafos, inclusive Ellmann, afirmam que ela o levou à casa da avó de Constance para apresentá-los, sabendo que seria uma boa esposa para o filho, e acompanhou o namoro com alegria. Na peça, Oscar se lembra da mãe observando da janela o namoro dos jovens amantes em Merrion Square e dos sonhos malucos da nacionalista Speranza para a Irlanda (p.21). Constance cita sua avó Mary Atkinson, afirmando amá-la por tê-la apresentado a Wilde (p.22) e relata que sua mãe a abandonou após a morte do pai (p.23). De acordo com Ellmann,

\begin{abstract}
Wilde foi com a mãe visitar uma mulher da família Atkinson, que os Wildes conheceram em Dublin. Sua anfitriã o apresentou a sua neta, Constance Lloyd, três anos mais jovem do que Wilde (Ela nasceu em 2 de janeiro de 1858). [...] Ela se interessava por música, pintura, bordado, sabia ler Dante em italiano (e leu), era lógica, matemática, tímida mas gostava de conversar. Wilde prestou muita atenção nela. Ao deixar a casa ele disse à Lady Wilde: 'A propósito, mamãe, estou pensando em casar com essa garota'. O pai de Constance morreu em 1874; ela não morava com sua mãe, que se casou novamente - 0 relacionamento delas foi tenso desde a infância. ${ }^{57}$
\end{abstract}

Podemos reconhecer algumas características citadas acima na Constance de The Secret Fall. Por exemplo, a personagem é, em muitos momentos, prática e lógica, quase matemática, no tratamento da situação. Além disso, ela afirma que ama surpreender as pessoas com as revelações das leituras que fez. (p.30).

Outro episódio transposto foi a trágica morte das irmãs de Wilde. De forma criativa, Kilroy imaginou uma situação na qual Constance pede ao seu então namorado Oscar que conte uma história que comece com "Era uma vez"

\footnotetext{
57 "Wilde went with his mother to call on a woman belonging to the Atkinson family, whom the Wildes had known in Dublin. His hostess introduced her granddaughter, Constance Lloyd, three years younger than Wilde (She was born on 2 January 1858). [...] She was interested in music, painting, embroidery, could read Dante in Italian (and did), was logical, mathematical, shy yet fond of talking. Wilde paid her marked attention. On leaving the house he said to Lady Wilde: 'By the by, mama, I think of marrying that girl'. Constance's father had died in 1874; she did not live with her remarried mother - their relationship was strained from her childhood." (p.234)
} 
(pp.24-25). O autor utiliza novamente um recurso épico quando, em cena, vemos Wilde narrando um terrível conto sobre três princesas que tiveram suas mortes relacionadas ao fogo: a primeira ardeu em febre, as outras duas estavam dançando quando se queimaram. Em seguida, ele revela que se trata de suas três irmãs que, de fato, morreram como foi narrado na história. Isola, a mais jovem e filha legítima do casal, ardeu em febre até a morte; Emily e Mary, que foram fruto de um relacionamento extraconjugal do pai de Oscar, morreram queimadas. Na biografia citada por Kilroy como uma das fontes de pesquisa, Mrs. Oscar Wilde: a Woman of some importance (1983), de Anne Clark Amor, há um relato sobre a morte de Emily e Mary:

\begin{abstract}
Uma tragédia abateu Sir William Wilde em novembro de 1871. Suas duas filhas ilegítimas, Emily e Mary, com vinte e quatro e vinte e dois respectivamente, foram a um baile em Drumaconnor, Condado de Monaghan. Era uma noite fria, com neve no chão, e chamas brilhantes ardiam na lareira. As duas garotas estavam entre os últimos convidados, quando o anfitrião pediu que Emily dançasse com ele. Enquanto eles dançavam sua saia rodada varreu a grelha e rompeu em chamas. Mary, vendo o perigo, correu em seu auxílio e seu vestido também foi devorado pelo fogo. O anfitrião levou-as para fora da casa e as rolou na neve, mas apesar de sua ação rápida ter extinto as chamas elas estavam queimadas demais para sobreviver. ${ }^{58}$
\end{abstract}

Se, por um lado, temos a admiração e a idealização de figuras femininas como Lady Wilde, Mary Atkinson, e as irmãs de Wilde, por outro, temos um repúdio à figura paterna. Kilroy acentua um aspecto em comum entre os três protagonistas: o relacionamento problemático com o pai. Douglas odiava seu pai, Lord Queensberry, condizendo com o que é relatado nas biografias. $\mathrm{Na}$

\footnotetext{
58 "A tragedy overtook Sir William Wilde in November 1871. His two illegitimate daughters, Emily and Mary, then aged twenty-four and twenty-two respectively, went to a ball at Drumaconnor, County Monaghan. It was a cold night, with snow on the ground, and a fire burned brightly on the hearth. The two girls were among the last remaining guests, when their host asked Emily to take a turn about the floor with him. As they danced her whirling skirt brushed the grate and burst into flames. Mary, seeing the danger, rushed to her aid and her dress was also enveloped by fire. Their host got them out of the house and rolled them in the snow but though his prompt action extinguished the flames they were too badly burned to survive." (p. 26)
} 
peça, ele recusa-se a falar sobre seu "montruoso pai" (p.32), que contava a todos que Wilde era um sodomita que corrompia rapazes, inclusive o filho. Desejando vingança, Douglas convenceu Wilde a processar seu pai por calúnia. Lord Queensberry, então, processou Wilde, alegando ser ele um homossexual corruptor de jovens. Oscar e Constance também não gostavam de seus pais, fato evidenciado no trecho abaixo:

\begin{abstract}
OSCAR - Eu desprezo meu pai.
CONSTANCE - Eu não quero falar sobre meu pai.

OSCAR - Eu falo constantemente sobre meu pai. O comportamento dele é tão horrível que acho que nunca conseguirei imitá-lo.

CONSTANCE - O papai foi preso! [...] Papai - Horace Watson Lloyd, advogado, trabalhava no número 11 da King's Bench Walk foi considerado culpado por se expor nos jardins de Temple perante as babás que ali passeavam. Pronto! Eu achei que nunca diria isso em voz alta.

OSCAR - Que extraordinário! Nós fomos atraídos por um interesse mútuo em patricídio. ${ }^{59}$
\end{abstract}

Um momento impressionante na peça é o Leilão, no qual Constance entra em cena, bêbada, falando sobre sua casa perfeita, porém vazia, esquelética e oca. De repente, os luxuosos móveis e objetos de decoração da famosa casa de Wilde, House Beautiful, aparecem flutuando numa espécie de Leilão surreal (p.34). A teatralização presente nesta cena permeia a peça desde o início com a ação dos Assistentes e suas marionetes, produzindo um efeito de ruptura com o ilusionismo e, novamente, confirmando a perspectiva épica da obra.

\footnotetext{
59 "OSCAR - I despise my father.

CONSTANCE - I don't wish to speak of my father.

OSCAR - I constantly speak about my father. His behaviour is so dreadful that I feel I shall never succeed in emulating him.

CONSTANCE - Papa was arrested! [...] Papa - Horace Watson Lloyd, barrister-in-law, practising at Number 11, King's Bench Walk was found guilty of, exposing himself in the gardens of the Temple before the perambulating nursemaids. There! I thought I could never say that aloud.

OSCAR - How extraordinary! We have been drawn to one another out of a mutual interest in patricide." (p.33)
} 
Alguns itens citados na cena condizem com os registros biográficos, tais como a cadeira que pertenceu ao historiador escocês Thomas Carlyle e sobre a qual Wilde escreveu grande parte de sua obra, os móveis brancos em estilo Anglo-Japonês ${ }^{60}$ elaborados pelo arquiteto e designer inglês Edward William Godwin (1833-1886) e o teto, no mesmo estilo, pintado pelo artista americano James Abbot McNeill Whistler (1834-1903) com dois dragões dourados e penas de pavão. Esses objetos aparecem nas biografias de Holland (1954, pp.30-32) e Ellmann (1988, pp.255-258), respectivamente:

À direita da porta da frente, entrando na casa, estava a sala de estudo de meu pai, na qual a maioria de sua obra foi escrita, numa mesa que pertenceu a Carlyle. [...] Geralmente tem sido afirmado que a decoração da casa foi realizada por E. W. Godwin, com o auxílio de Whistler, mas isto só é verdadeiro para o térreo e o primeiro andar. ${ }^{61}$

Foi Wilde quem determinou como eles deveriam viver, em que avenida Whistleriana e em qual estilo Godwiniano. [...] $O$ teto originalmente tinha dois dragões dourados em lados opostos pintados por Whistler, estes davam caminho até certo ponto a grandes penas inseridas no gesso, também por sugestão de Whistler. Penduradas nas paredes verdes estavam pequenas litografias com molduras brancas de Whistler e Mortimer Menpes. ${ }^{62}$

Anne Clark Amor (1983) relata o triste episódio do leilão, expressando em alguns momentos sua indignação. De acordo com a biógrafa, o modo como o leilão dos bens foi realizado foi um ultraje; além disso, uma grande

${ }^{60} \mathrm{O}$ estilo Anglo-Japonês refere-se ao período entre 1872 e 1900, quando houve um movimento de apreciação da cultura asiática, especialmente a japonesa, no Reino Unido. Tal movimento influenciou a arquitetura e a decoração.

61 "To the right of the front door, as one entered the house, was my father's study, in which most of his work was done, at a table that had once belonged to Carlyle. [...] It has often been asserted that the decoration of the house has been carried out by E. W. Godwin, with help from Whistler, but this was true only of the ground and first floors."

62 "It was Wilde who determined how they should live, on what Whistlerian avenue and in what Godwinian style. [...] The ceiling originally had two gold dragons at opposite corners painted by Whistler; these gave way at some point to large Japanese feathers inserted into the plaster, also at Whistler's suggestion. Hung on the green walls were small white-framed lithographs by Whistler and Mortimer Menpes." 
quantidade de bens valiosos foi roubada, e o resto vendido a preços escandalosamente baixos:

Toda a biblioteca de Wilde de primeiras edições autografadas e raras foi empacotada em lotes de vinte ou trinta livros que foram vendidos por duas ou três libras. Alguém se gabou por ter arrematado um Whistler por um xelim. Constance costumava guardar todas suas cartas de Oscar numa caixinha de couro azul, mas alguém foi cruel o bastante para roubar a caixa e seu conteúdo. Vários manuscritos e cartas pessoais pertencentes a Oscar desapareceram sem deixar rastro, e todos os brinquedos dos filhos foram vendidos por trinta xelins. Por meses os meninos pediram seus trens e soldadinhos de chumbo, e se perguntavam por que isso sempre fazia Constance chorar. Eles não sabiam nada sobre a venda. ${ }^{63}$

Na segunda parte da peça também há referência a esse fato, quando

Constance conta a Oscar, na prisão, que o filho mais novo, Vyvyan, sempre perguntava sobre o destino de seus soldadinhos; revela também que todos os brinquedos das crianças tinham sido vendidos por apenas trinta xelins no leilão (p.54). Em sua autobiografia, Vyvyan Holland conta:

Por meses, meu irmão e eu pedimos nossos soldados, nossos trens, e outros brinquedos, e não podíamos entender por que isso transtornava nossa mãe, visto que não sabíamos nada sobre a venda. Foi apenas quando vi o catálogo muitos anos depois, que eu compreendi por que minha mãe ficava transtornada. A venda consistiu em 246 lotes; o número 237 era 'Uma grande quantidade de brinquedos'; eles foram vendidos por trinta xelins. ${ }^{64}$

\footnotetext{
63 "Oscar's entire library of rare and autographed first editions was bundled up in lots of twenty or thirty books and sold off for two or three pounds per lot. Somebody boasted of getting a Whistler for a shilling. Constance used to keep all her letters from Oscar in a little blue leather case, but somebody was heartless enough to steal the case and its contents. Various manuscripts and personal letters belonging to Oscar vanished without trace, and all the children's toys were sold off for thirty shillings. For months afterwards the boys asked for their trains and tin soldiers, and wondered why this always made Constance cry. They knew nothing of the sale." (p.173)

64 "For months afterwards, my brother and I kept asking for our soldiers, our trains, and other toys, and we could not understand why it upset our mother, since of course we knew nothing about the sale. It was only when I saw the catalogue, many years later, that I realized why my mother had been upset. The sale consisted of 246 lots; number 237 was "A large quantity of toys"; they realized thirty shillings." (p.50)
} 
Após o Leilão, há uma simulação da queda de Constance. Comparando com a biografia escrita por Anne Clark Amor, verifica-se que a autora atribui a queda a um tropeção no carpete da escadaria: "Constance tropeçou num carpete solto da escadaria da House Beautiful e caiu escada abaixo. Parece que ao tentar se salvar ela machucou seu braço gravemente; [...] sua coluna foi afetada e o prognóstico não era bom" ${ }^{n 5}$. No entanto, a simulação da queda, numa coreografia que conta com o auxílio dos Assistentes, sugere ser Constance uma vítima, uma marionete das "Figuras do Destino", visto que não aceita passivamente que a levem até a escadaria. Ao contrário, ela grita e luta para não ser arrastada (p.35). Observa-se novamente a importância da teatralização para Kilroy, que optou por coreografias cênicas e linguagem poética, num processo de apropriação e reformulação, do que pela mera reconstituição realista de uma queda acidental.

É relevante salientar a importância da escadaria móvel que, além de ser utilizada na dramatização da queda, também, em cena posterior, é invertida, funcionando como um banco de réus durante um monólogo de Oscar no qual ele simula ser o juiz ao dar a sentença e relata detalhes do julgamento:

\begin{abstract}
OSCAR - E, você, Wilde, teve a audácia de processar um pai por calúnia, sabendo muito bem que ele estava meramente protegendo seu filho de sua influência horrível. Que o pai era um nobre do Reino, Lord Queensberry, e seu filho, Lord Alfred Douglas, um membro da aristocracia, simplesmente dá alguma indicação da extensão de sua insolência arrogante. Você, Wilde, tem sido o corruptor de jovens. Que muitos deles eram de classe baixa, cavalariços, entregadores de jornal, criados e similares, dá alguma indicação de sua vulgaridade. ${ }^{66}$
\end{abstract}

\footnotetext{
65 "Constance tripped on a loose stair-carpet in the House Beautiful and fell from top to bottom of the long flight. It would appear that in trying to save herself she injured her arm rather badly; [...] her spine was affected and the prognosis was not good." (p.155)

66 "OSCAR - And, you, Wilde, have had the audacity to prosecute a father for libel, knowing full well that he was merely protecting his son from your foul influence. That the father was a peer of the realm, Lord Queensberry, and his son, Lord Alfred Douglas, a member of the aristocracy, simply gives some indication of the range of your upstart insolence. You, Wilde, have been the
} 
Os monólogos, como o citado anteriormente, são momentos relevantes e possuem caráter confessional e narrativo. Na maioria, a personagem se dirige ao público, de modo distanciado da ação, e explica alguns fatos biográficos. Tais cenas apresentam elementos épicos, pois há uma ruptura na perspectiva realista e ilusionista.

Kilroy também optou por incluir, por meio de comentários dos protagonistas, várias personagens baseadas em pessoas reais com o intuito de explorar as lacunas biográficas, criando situações e diálogos que não constam em quaisquer biografias ou cartas. Um exemplo é a visita do ator inglês Charles Brookfield à casa de Constance, a fim de contar a ela sobre os encontros homossexuais de Oscar durante as reuniões teatrais em Little College Street. Segundo as biografias e relatos sobre o julgamento de Wilde, verifica-se que Brookfield auxiliou, de fato, a acusação com seus depoimentos. Douglas comenta sobre a provável causa da antipatia do ator pelo escritor:

DOUGLAS - Aquele ator, Brookfield. Lembra? Como ele reuniu a sujeira sobre nós, pra contar. E por quê? Porque você o humilhou. Me contaram isso. Não se deve usar luvas durante o chá da tarde, Brookfield. Isto é o que você disse para ele. Em público! E justo na América! Você cometeu o pecado capital. Você corrigiu um inglês numa questão de etiqueta. Nunca faça isso. Especialmente se você não for inglês. Especialmente se ele for um ator e treinado para imitar os melhores. ${ }^{67}$

corruptor of young men. That many of them were of the lower classes, grooms, newspaper boys, valets and the like, gives some indication of your vulgarity." (p.41)

67 "DOUGLAS - That actor. Brookfield. Remember? How he gathered the dirt on us, so to speak. And why? Because you humiliated him. I heard about it. One should not wear gloves during afternoon tea, Brookfield. That's what you said to him. In public! And in America, of all places! You committed the cardinal sin. You corrected an Englishman in a matter of etiquette. One never does that. Particularly if one is not English oneself. Particularly if he is an actor and trained to imitate his betters." (p.64) 
Sobre o fato, Ellmann relata que foi na América que ele (Wilde) irritou Brookfield ao comentar que permanecer de luvas durante o chá era deselegante. Ainda afirma que o ator jamais o perdoou. (1988, p.198) Ellmann também comenta a humilhação sofrida por Wilde na plataforma de Clapham Junction,

\begin{abstract}
A mudança (para a prisão Reading) ocorreu em 21 de novembro, e demonstrou ser a experiência mais humilhante da vida de Wilde. Algemado e vestido como prisioneiro, ele teve que esperar na plataforma de Clapham Junction das duas às duas e meia numa tarde chuvosa. Uma multidão se formou, primeiro rindo e então zombando dele. Um homem reconheceu que aquele era Oscar Wilde, e cuspiu nele. 'Durante o ano seguinte ao que aconteceu comigo,' Wilde escreveu em De Profundis, 'Eu chorava todos os dias na mesma hora e pelo mesmo período de tempo'. ${ }^{6}$
\end{abstract}

Na peça, porém, Oscar conclui que todo o sofrimento, não só nesse triste episódio, mas também na prisão, valeu a pena: “Valeu a pena, Oscar? Valeu a pena, meu amigo. Valeram todas as piadas baratas. Valeu a humilhação, algemado diante da enorme multidão na plataforma de Clapham Junction. [...] Quando você ceia com os deuses deve pagar o preço total da entrada" ${ }^{\prime \prime}$.

De forma artística, Kilroy transpõe para o palco o momento da prisão de Oscar: após outro longo monólogo, no qual ele relata sua estada no quarto número 53 do Cadogan Hotel e a chegada dos policiais para levá-lo à prisão, uma jaula é colocada no palco. Nesta cena, temos um excelente exemplo de

\footnotetext{
68 "The move (to Reading prison) took place on 21 November, and proved to be the single most humiliating experience of Wilde's life. Handcuffed and in prison clothing, he had to wait on the platform at Clapham Junction from two to half past two on a rainy afternoon. A crowd formed, first laughing and then jeering at him. One man recognized that this was Oscar Wilde, and spat at him. 'For a year after that was done to me,' Wilde wrote in De Profundis, 'I wept every day at the same hour and for the same space of time'." (pp.495-496)

69 "Was it worth it, Oscar? It was worth it, my friend. Worth all the cheap jokes. Worth the humiliation in manacles before the gaping crowd on the platform of Clapham Junction. [...] When one sups with the gods one must pay the full price of admission." (p.21)
} 
transcodificação da narrativa em ações, sons e fortes imagens visuais. A sonoplastia é feita por notas discordantes, risadas e aplausos, gritos, choro de agonia, um abrir e bater infinito de celas de prisão, som de pés se arrastando pelos corredores e indecifráveis gritos de comando. Os Assistentes, então, saltam sobre Oscar, rasgando suas roupas e arrancando seus cabelos. Ele é arrastado, despido, torturado e jogado na jaula. Tal sequência sugere ao público todo o sofrimento físico e moral que o Oscar histórico suportou devido à intolerância da sociedade.

A Segunda Parte da peça tem início com a sombria Missa dos Mortos, produzindo, de acordo com Kilroy, um efeito de pesadelo fantástico (1997, p.50). Segundo a rubrica, ouve-se canto gregoriano com coral e órgão, e orações em latim. As velas acentuam o tom sombrio da cena. Em seguida, Constance é colocada numa segunda jaula, simulando sua visita à Prisão para dar a triste notícia sobre o falecimento de Lady Wilde. Oscar comenta sobre a aparição de sua mãe na cela no dia anterior. Esse episódio é descrito em Ellmann:

\begin{abstract}
Ele teve uma visão de sua mãe. Ela estava vestida para sair, e ele the pediu que tirasse o chapéu e a capa e sentasse. Ela balançou a cabeça tristemente e desapareceu. No dia seguinte, 19 de fevereiro de 1896, ele foi chamado para conversar com sua esposa em uma sala privada. A própria Constance não estava se sentindo bem mas, informada por Willie sobre a morte de Lady Wilde, viajou da Itália para contar a seu marido a notícia, pois ela sabia que ele sentiria uma grande dor com a perda da mãe. 'Eu já sabia', ele disse, e contou a ela sua visão. ${ }^{70}$
\end{abstract}

\footnotetext{
70 "He had a vision of his mother. She was dressed for out-of-doors, and he asked her to take off her hat and cloak and sit down. She shook her head sadly and vanished. The next day, 19 February 1896, he was summoned to talk to his wife in a private room. Constance herself had not been well but, notified by Willie of Lady Wilde's death, she had travelled from Italy to tell her husband the news, which she knew would be excruciatingly painful to him. 'I knew it already', he said, and told her of his vision." (p.498)
} 
O exílio de Constance e filhos na Suíça e na Itália é encenado numa espécie de pantomima com o auxílio dos Assistentes que, com algumas marionetes vestidas como viajantes, simulam as viagens realizadas pelas personagens. Podemos identificar traços épicos nessa cena, pois trata-se de uma representação de uma sequência narrativa. Segundo Rosenfeld (2006, p.112), a pantomima não é uma arte propriamente dramática "por Ihe faltarem as palavras do diálogo que é básico para a concepção do drama ocidental", mas é um ótimo recurso para ilustrar uma narrativa.

Uma das cenas mais tensas é a simulação do possível estupro sofrido por Constance, na qual Kilroy põe em cena uma enorme marionete representando o pai de Constance. A princípio, não encontrei evidências sobre esse fato nas biografias e, diante da dúvida, resolvi consultar novamente 0 autor sobre as fontes ou razões para a cena. Em resposta, Thomas Kilroy afirmou:

\begin{abstract}
Isso é como eu imaginei. Claro que tinha material de apoio na história do pai dela (seu comportamento sexual problemático, por exemplo) e sua própria queda misteriosa. Acima de tudo, o tratamento dado a ela pelo pai do modo como foi retratado na peça, não podia contradizer quaisquer fatos conhecidos. Eu não acho que contradiz. A propósito, não é conclusivamente um estupro. Este ponto é deixado em aberto na peça. $^{71}$
\end{abstract}

$\mathrm{Na}$ fala final, o autor transpõe um trecho da última carta de Constance. Tal carta é citada na autobiografia de seu filho. Vyvyan Holland conta, de forma comovente, sobre a deterioração da saúde da mãe:

\footnotetext{
71 "This is how I imagined it. Of course there had to be supporting material in the story of her father (his problematic sexual behaviour, for instance) and her own mysterious fall. Above all, her treatment by her father as portrayed in the play, shouldn't contradict any known facts. I don't think it does. It is not conclusively a rape, by the way. That point is left open in the play." (Email, 07/07/2010)
} 
Seus problemas familiares minaram seus poderes de resistência, e as lesões que sofreu na queda da escadaria na rua Tite foram mais severas do que tinha percebido a princípio. A paralisia se desenvolveu em sua coluna e em seu braço direito. Por alguns meses ela teve dificuldade em escrever e precisou usar uma máquina de escrever para sua correspondência. Mas um dia, no início de abril, eu recebi uma longa carta dela com sua própria letra, que deve ter lhe custado um prodigioso esforço, na qual ela mencionou meu pai. Ela escreveu: 'Tente não ser severo com seu pai, lembre-se que ele é seu pai e que te ama. Todos os problemas dele vieram do ódio de um filho pelo pai, e o que quer que seja que tenha feito ele tem sofrido amargamente.' Esta foi sua última carta para mim. Ela foi para uma clínica em Gênova logo depois, para uma operação para aliviar a pressão em sua coluna que estava the causando uma dor incessante. $^{72}$

Joyce Bentley, em The Importance of Being Constance: a Biography of

Oscar Wilde’s Wife (1983), comenta sobre a operação e morte de Constance

em 1898. É interessante observar que este trecho da biografia é permeado

pela interpretação e opinião pessoal da biógrafa, demonstrando ser a biografia

um gênero que apresenta fatos históricos, elementos ficcionais e, inclusive, a

opinião do autor-biógrafo:

Finalmente a operação para aliviar a pressão em sua coluna, que nessa época foi apontada como a causa da dor insuportável, seria realizada. Constance tinha a sensação de que tudo agora estava em ordem, e a morte, se viesse, traria libertação de estar interminavelmente e inseparavelmente ligada ao homem com quem tinha se casado. Incapaz de se desfazer dele e esquecê-lo, era quase um caso de não ser capaz de viver com ele e não ser capaz de viver sem ele. A morte, se viesse, faria justiça a sua própria dignidade [...] Era impossível refazer o passado. Ela e Oscar tinham modelado seus próprios destinos e por necessidade agora tinham se tornado figuras vagas e embaçadas, cobertos por mal-entendidos e deturpações. Constance nunca se recuperou da operação; talvez tenha sido tarde demais e a paralisia estivesse muito avançada; talvez ela estivesse

\footnotetext{
72 "Her domestic troubles had lessened her powers of resistence, and the injuries she had sustained in her fall downstairs in Tite Street were more severe than had at first been realized. Paralysis had developed in her spine and in her right arm. For some months she had been having difficulty in writing and she had taken to using a typewriter for her correspondence. But one day, at the beginning of April, I received a long letter from her in her own handwriting, which must have cost her a prodigious effort. In it she mentioned my father. She wrote: 'Try not to feel harshly about your father; remember that he is your father and that he loves you. All his troubles arose from the hatred of a son for his father, and whatever he has done he has suffered bitterly for.' This was her last letter to me. She went into a nursing home in Genoa shortly afterward, for an operation to relieve the pressure on her spine that was causing her ceaseless pain." (pp.112113)
} 
enfraquecida física e emocionalmente - até mesmo mentalmente pelos prolongados problemas que a cercavam. ${ }^{73}$

Bentley afirma que "era impossível refazer o passado"; no entanto, tal impossibilidade é realizada no palco por Thomas Kilroy no momento em que a personagem Constance propõe a Oscar uma jornada secreta ao passado, para desfazer os "mal-entendidos e deturpações".

Em relação ao último monólogo de Douglas, observamos que a personagem antecipa seu futuro "normal", visto que toda ação já aconteceu: "Quando tudo terminou, eu senti como se tivesse sido libertado de um círculo branco maligno. Livre finalmente! E eu sobrevivi a ambos. Por cerca de meio século, na verdade. Casei, tomei juízo"74. Essa fala caracteriza o eu-épico, distanciado da ação da peça, que "narra" e comenta sobre a personagem. É relevante salientar que Lord Alfred Douglas é retomado por Kilroy no monólogo My Scandalous Life (2004), em que um Douglas com mais de setenta anos, que se casou, se separou e teve um filho, reflete sobre o passado. Enfim, como o trecho acima demonstra, ele teve uma vida aparentemente normal após seu relacionamento com Wilde; entretanto, não é o que veremos na análise da peça no terceiro capítulo desta dissertação.

\footnotetext{
73 "At last the operation to relieve the pressure on her spine, which was by this time reported to be the cause of unbearable pain, was to take place. Constance had a sense of everything being now in order, and death, if it came, would bring release from being interminably and inextricably bound to the man she had married. Unable to cast him off and forget about him, it was almost a case of not being able to live with him and not being able to live without him. Death, if it came, would do justice to her own dignity [...]. It was impossible to remake the past. She and Oscar had modeled their own destinies and of necessity now had become vague and misted figures, overlaid with misunderstandings and misrepresentation. Constance never recovered from the operation; perhaps she had left it too late and the paralysis was to far advanced; perhaps she had been weakened physically and emotionally - even mentally - by the long-drawn-out troubles which surrounded her." (pp. 152-153)

74 "When it all ended I felt as if I had been released from a malevolent white circle. Free at last! And I outlived them both. By nearly half a century, as a matter of fact. Married, settled down." (pp.64-65)
} 
Kilroy encerra The Secret Fall com uma cena num café parisiense, em que quatro Assistentes carregam Marionetes de cavalheiros passando pela mesa de Oscar, que estende a mão para mendigar. Vemos mais uma vez a importância da ação dos Assistentes com as Marionetes representando, numa sequência narrativa, a humilhação que Oscar sofreu. Segundo Ellmann,

\begin{abstract}
A cantora de ópera Nellie Melba, que o conheceu em Londres, estava caminhando pelas ruas de Paris uma manhã. Um homem alto e mal vestido cambaleava na esquina, o colarinho mostrava o pescoço. 'Madame Melba', disse uma voz, 'você não sabe quem eu sou? Eu sou Oscar Wilde, e eu vou fazer uma coisa terrível. Eu vou te pedir dinheiro.' Ela pegou tudo o que tinha em sua bolsa e deu a ele; ele murmurou um agradecimento e foi embora. Ela se lembrou do primeiro encontro deles há muito tempo atrás, quando ele disse, 'Ah, Madame Melba, eu sou o Senhor da Linguagem e você é a Rainha da Música, então eu suponho que devo escrever a você um soneto. ${ }^{75}$
\end{abstract}

Uma discussão levantada pela obra remete à questão das aparências. Wilde era um Dandy, figura típica em Londres e Paris no final do século XIX. Vestia-se muito bem e valorizava a pose, a aparência, o exibicionismo e o fingimento. As máscaras usadas pelos Assistentes sugerem esse jogo de aparências, de mascarar/desmascarar. No entanto, apesar de Oscar ser um mestre das aparências (aspecto sugerido por algumas falas de Constance quando pede para ele parar de ser um ator na vida real, p.11), é Constance que, na peça, domina a arte de fingir e dissimular. Porém ela não o faz com o intuito de exibir-se ou manter uma pose, mas para ocultar seu sofrimento e vergonha:

\footnotetext{
75 "The opera singer Nellie Melba, who had known him in London, was walking along the streets of Paris one morning. A tall, shabby man lurched around the corner, his collar turned up to his neck. 'Madame Melba', said a voice, 'you don't know who I am? I'm Oscar Wilde, and I'm going to do a terrible thing. I'm going to ask you for money.' She took all she had in her purse and gave it to him; he muttered his thanks and went. She remembered their first meeting long ago, when he had said, 'Ah, Madame Melba, I am the Lord of Language and you are the Queen of Song, and so I suppose I shall have to write you a sonnet."' (p.573)
} 
CONSTANCE - As pessoas continuam me perguntando: Como era, Constance, como realmente era ser casada com ele? Claro, eles estavam pensando sobre você sabe o quê. Era como se eles estivessem me despindo com os olhos. Por quê?, eu respondo a eles na minha melhor voz de esposa, era teatro, meus queridos, teatro! Teatro de todas as formas! Vocês sabem como Oscar é! Todos os dias uma performance diferente. Com trocas frequentes de vestuário, claro. $^{76}$

Observe este outro trecho em que Constance comenta a capacidade de fingimento das mulheres:

CONSTANCE - O que você tem que entender é que nós mulheres somos treinadas desde o nascimento para fingir. De outra maneira, veja, os homens seriam incapazes de se comportar como se comportam. Isto é o que é conhecido como sociedade. É isso. Está vendo? Posso falar como Oscar também. ${ }^{77}$

O casamento também é um dos temas abordados. Essa instituição já enfrentava uma crise no final do século XIX, pois era vista pelos movimentos artísticos dessa época, como Realismo e Naturalismo, como uma proteção para manter as aparências. A maioria das obras desse período narra histórias de casais e famílias aparentemente perfeitos, porém com profundas máculas causadas pelo adultério. A peça apresenta também essa visão pessimista. Para Douglas, o casamento era uma obrigação, uma forma de proteção e invisibilidade contra os comentários maldosos da sociedade (p.26). Oscar questiona "O que é o casamento sem o adultério? Os franceses só traem porque amam as mulheres" (p.37). O próprio enredo da peça nos leva a refletir sobre a fragilidade e a provável falência do casamento.

\footnotetext{
76 "CONSTANCE - People keep asking me: What was it like, Constance, really like, to be married to him? Of course, they're thinking of you-know-what. It's as if they are undressing me with their eyes. Why?, I answer them in my best wifely voice, it was theatre, m'dears, theatre! Theatre all the way! You know what Oscar is like! Every day a different performance. With frequent costume changes, of course." (p.15)

77 "CONSTANCE - What you have to understand is that we women are trained from birth to conceal. Otherwise, you see, men would be unable to behave as they do. This is what is known as society. There. See? I can speak like Oscar, too." (p.30)
} 
De acordo com Nicholas Grene (2002), o ponto forte da peça é a elaborada linguagem visual. De fato, essa é uma das marcas da dramaturgia de Kilroy que pode ser constatada desde suas primeiras produções como Tea and Sex and Shakespeare (1976) ou Talbot's Box (1977): cenários complexos e fortes imagens construídas a partir de elementos cênicos e performance dos atores.

Ao analisar o cenário, Grene observa que duas estruturas móveis são centrais: o círculo branco e a escadaria. De acordo com o crítico, o círculo branco colocado no chão produz o efeito de arena circense na qual as personagens atuam, ou é elevado, sugerindo uma grande lua ou uma hóstia gigante. Já a escadaria, para Grene, tem importância fundamental:

\begin{abstract}
Até mais crucial é a escadaria na qual Constance conduz seus filhos à cama. Duplica-se como o banco de réus no qual Oscar aparece; é da escadaria abaixo que Constance literalmente cai no acidente que a deixa aleijada e a mata no final; e é sobre a escadaria que a queda secreta de seu abuso sexual na infância também ocorre. Há aqui mais do que inventividade teatral e ingenuidade. As vidas dos três interligadas na peça são interpretadas como as vidas da mente e do corpo, a pessoa e a persona, dirigidas e apresentadas pelas forças internas $e_{78}$ externas daquelas vidas que lhe deram forma $e$ significado. ${ }^{78}$
\end{abstract}

Kilroy comenta, em email, que o círculo branco representa basicamente um espaço enclausurado, como uma arena circense. $O$ autor afirma, ainda, que

\footnotetext{
78 "Even more crucial is the staircase up which Constance conducts her children to bed. It doubles as the dock in which Oscar appears; it is the staircase down which Constance literally falls in the accident which cripples and ultimately kills her; and it is the staircase on which the secret fall of her childhood sexual abuse also takes place. There is more here than theatrical inventiveness and ingenuity. The lives of the three interlocked selves of the play are staged as the lives of the mind and of the body, the person and the persona, directed and presented by the forces both inside and outside those lives that give them shape and significance."
} 
gosta de "usar clausuras no palco porque uma das coisas sobre as quais ele escreve é a luta das pessoas para escapar de prisões de diversos tipos". ${ }^{79}$

É importante, neste ponto, retomar os traços épicos, visto ser um aspecto fundamental em The Secret Fall of Constance Wilde. Como já foi comentado anteriormente, uma peça baseada em registros históricos é, por natureza, "não-dramática", pois faz referência a algo exterior ao drama, sendo uma representação secundária de algo primário.

Observamos, desde a primeira rubrica, características como a descontinuidade temporal, por meio do retorno cênico a tempos passados (a jornada secreta), e a intervenção dos Assistentes manipulando a história como se fossem narradores, inclusive transformando, em cena, os debilitados Oscar e Constance em jovens. Segundo Anatol Rosenfeld, "quanto ao passado, o drama puro não pode retornar a ele, [...] qualquer interrupção ou retorno cênico a tempos passados revelariam a intervenção de um narrador manipulando a história." (2006, p.31)

Além disso, em diversos momentos, Constance, Oscar e Douglas se dirigem ao público, distanciando-se da ação da peça, para narrar alguns eventos ou explicar determinados aspectos, interrompendo a situação dialógica entre as personagens. Também foi constatado que, em várias passagens, há a suspensão da ilusão, como os momentos em que as marionetes e os Assistentes estão em cena, e o Leilão "surreal" em que os móveis flutuam.

A pesquisa, de acordo com o próprio Kilroy, é uma etapa essencial para uma peça baseada em biografias, porém o processo de composição deve ser

\footnotetext{
79 "Basically the circle represents an enclosed space, like a circus ring, inside which the performers must perform. I like using enclosures on stage because one of the things I write about is the struggle of people to escape entrapment of different kinds." (email, 15/10/2010)
} 
direcionado pela imaginação do artista. Somente desse modo pode-se compor uma obra de arte e não uma simples reprodução de fatos históricos.

De fato, Thomas Kilroy não se limitou à representação visual do que consta nas biografias e cartas, preferindo reformular o material, acentuando, acrescentando, omitindo e criando. Dessa forma, conclui-se que, para a composição de The Secret Fall of Constance Wilde, houve um processo de apropriação dos registros históricos e biográficos, a fim de recontar a história de uma personagem marginalizada reinventando ou recuperando sua voz, outrora reprimida.

Foi constatado, ao longo deste estudo, que Kilroy utilizou recursos teatrais diversos durante o processo de apropriação e transposição da biografia para o palco, tais como Assistentes e Marionetes, numa nítida alusão ao teatro oriental Kabuki e Bunraku. Também foram utilizadas estruturas móveis no cenário como o círculo branco, a escadaria e as jaulas, nos quais foram encenados, ou apenas sugeridos, episódios biográficos relevantes como o julgamento de Wilde e a queda de Constance.

Apesar de Oscar Wilde e Lord Alfred Douglas corresponderem às figuras históricas em muitos aspectos, verificou-se, neste estudo, que Constance foi fruto da imaginação do dramaturgo. Após complexo processo de pesquisa, no qual consultou biografias, cartas e livros sobre a época, Kilroy criou uma Constance indignada e disposta a revisitar os tristes fatos de sua vida por meio de uma jornada secreta, a fim de conhecer-se, visto que a personagem não aceita mais que essa história seja contada como a história de Oscar Wilde, mas como a história de ambos, Constance e Oscar: "Nosso casamento. Nossos filhos." (p.17). 
Enfim, esta é a oportunidade para Constance Wilde contar essa famosa história sob o seu ponto de vista, e não ser apenas uma vítima, uma marionete do Destino. 


\section{CAPÍTULO 3}

\section{MY SCANDALOUS LIFE: \\ Um outro Lord Alfred Douglas}

Oscar Wilde, did you say? [...] All that was nearly fifty years ago. It's my life now.

Em sua única peça escrita em forma de monólogo, Thomas Kilroy retoma a figura histórica de Lord Alfred Douglas, também conhecido como Bosie, agora não mais o jovem e provocante Douglas de The Secret Fall of Constance Wilde (1997), mas um homem com setenta e quatro anos lutando para recuperar sua identidade, pois não quer ser conhecido apenas como 0 amante de Oscar Wilde.

Para analisar a apropriação e transposição da biografia para o teatro, foram utilizadas como fontes principais a biografia Oscar Wilde (1988), de Richard Ellmann, mencionada no capítulo anterior, e Bosie: A Biography of Lord Alfred Douglas (2000), de Douglas Murray, considerada uma das mais completas e imparciais biografias sobre Bosie. Completa, porque traz inúmeras citações e referências às suas cartas e biografias anteriores, como a de $\mathrm{H}$. Montgomery Hyde, Lord Alfred Douglas: a Biography (1984). Imparcial, porque algumas biografias foram escritas por amigos e admiradores, como a de Rupert Croft-Cooke (personagem citado na peça), Bosie: Lord Alfred Douglas, his Friends and Enemies (1963), além de The Autobiography of Lord Alfred 
Douglas (1929), em que o autor, devido à conversão ao Catolicismo, amenizou os escândalos de sua relação com Wilde e outros relacionamentos homossexuais.

Ao escolher My Scandalous Life (2004) como um dos objetos desta pesquisa, a primeira questão foi: Por que Thomas Kilroy retoma essa figura histórica? Felizmente, tive o enorme privilégio de ter a resposta do próprio autor em email enviado em 7 de julho de 2010:

Eu fiquei extremamente interessado pela vida de Lord Alfred Douglas e sua família após a morte de Wilde. Também escrevi uma peça (No Jardim do Asilo) para a rádio irlandesa baseada em um fato curioso. É que Raymond Douglas, filho de Alfred Douglas, e Lucia Joyce, filha de James Joyce, estiveram por treze anos no mesmo hospital psiquiátrico na Inglaterra. Ambos eram esquizofrênicos. Não há evidências de que eles se encontraram mas, em minha peça, eles se encontram. Espero que seu trabalho esteja indo bem, Tom. ${ }^{80}$

De fato, a vida de Lord Alfred Douglas após a morte de Wilde não foi tão pesquisada e abordada quanto os anos de sua juventude ao lado do grande autor irlandês e, diante disso, pode-se afirmar que em My Scandalous Life a transposição da biografia para o palco deu-se pelo processo de apropriação dos registros históricos (SANDERS, 2006, p.139) a fim de recuperar uma voz perdida ou reprimida, de recontar um período obscuro da vida de Douglas, reinventando sua voz.

Outro aspecto que suscitou questionamentos referentes às escolhas do autor (especificamente, da forma teatral) foi o fato de Kilroy escrever, pela primeira vez, um monólogo. No artigo "Look Who's Talking, Too: The

\footnotetext{
80 "I became extremely interested in the life story of Lord Alfred Douglas and his family after Wilde's death. I've also written a radio play (In the Garden of the Asylum) for Irish radio based upon a curious fact. This is, that Raymond Douglas, son of Alfred Douglas, and Lucia Joyce, daughter of James Joyce, spent thirteen years together in the same mental hospital in England. They were both schizophrenic. There is no evidence that they ever met but in my play they do. Hope your work is going well, Tom"
} 
Duplicitous Myth of Naïve Narrative"81 (2006), Eamonn Jordan afirma que, enquanto o teatro internacional, em geral, dos anos 80 e 90 apresentava grandes produções teatralizadas e estilizadas, os monólogos tornaram-se uma marca do drama irlandês ${ }^{82}$. Entretanto, alguns críticos afirmam que o teatro de Thomas Kilroy identifica-se mais com o teatro internacional (especialmente, o europeu) com suas produções estilizadas e complexas, do que com o teatro irlandês. Também é fato a tendência por montagens de monólogos na Irlanda a partir do final da década de 80 , principalmente monólogos para um ator. Uma hipótese levantada seria a busca de Kilroy por formas ainda não experimentadas por ele e, ao mesmo tempo, que representassem uma tendência em seu país, visto que as formas artísticas vigentes geralmente são reflexo de um contexto externo.

Jordan seleciona alguns motivos para a proliferação de monólogos no teatro irlandês: primeiramente, um monólogo representa um baixo risco financeiro, pois envolve poucos atores e profissionais e tem um custo menor em relação aos cenários e figurinos. O crítico também afirma que esse período de invasão dos palcos por monólogos coincide com o surgimento do Celtic Tiger, quando características como independência e individualismo eram muito valorizadas. Outro motivo apontado é o fato do monólogo se assemelhar ao sacramento da confissão, presente num país de tradição católica como a Irlanda. De acordo com Jordan, a religião irlandesa "conecta a narrativa ao espaço/sacramento confessional do Catolicismo Romano, o processo punitivo

\footnotetext{
81 JORDAN, Eamonn. "Look Who's Talking, too: The Duplicitous Myth of Naïve Narrative". In: WALLACE, Clare (ed.). Monologues: Theatre, Performance, Subjectivity. Prague: Litteraria Pragensia, 2006.

82 "While international theatre, in the main, from the late 1980s and into 1990s pursued big scale [...] stylized, and theatricalized productions [...] monologues increasingly became a staple of Irish drama." (p.125)
} 
de purificação em que a absolvição está acessível" ${ }^{33}$. De fato, o espectador ou leitor tem a impressão de que Lord Alfred Douglas, apesar das mentiras e distorções relatadas na primeira metade do monólogo, está em busca de purificação e absolvição de seus pecados: "Eu vim para a luz e deixei para trás os lugares da iniquidade! Eu fui salvo da minha vida passada e deixei para trás os pecados da minha mocidade.. ${ }^{84}$ Em contrapartida, pode-se considerar a postura de Douglas uma paródia do Cristianismo, pois cita algumas expressões e canta músicas cristãs; no entanto, não se comporta como tal, visto que não demonstra arrependimento verdadeiro, por exemplo, quando fala sobre seu relacionamento com Wilde no passado.

Além de Lord Alfred Douglas, temos também como personagens seu filho Raymond, um homem de quarenta e dois anos, e a empregada Eileen, descrita como uma gigantesca irlandesa. Embora não tenham nenhuma fala, eles são extremamente importantes para o desenvolvimento do monólogo. É pertinente ressaltar que, apesar de existirem as personagens Raymond e Eileen, o público tem acesso à narrativa unicamente pelo ponto de vista de Lord Alfred Douglas, que muda a versão dos fatos diversas vezes, nos deixando desconfiados em relação à veracidade dos acontecimentos relatados.

O monólogo tem como cenário, ao contrário dos exuberantes e experimentais cenários das peças anteriores, apenas a sala do apartamento da ex-esposa de Douglas, Olive, em Hove, Inglaterra. De acordo com Douglas Murray, "em 11 de fevereiro de 1944, Douglas passou várias horas com sua esposa, segurando sua mão enquanto ela jazia semiconsciente na cama. $\mathrm{Na}$

\footnotetext{
83 "[...] connect narrative to the confessional space/sacrament of Roman Catholicism, the purging and retributive process where absolution is available." (p.130)

84 "I have come into the light and left behind the places of iniquity! I have been saved from my past life and left behind the sins of my youth!" (p.20)
} 
manhã seguinte, a criada de Olive telefonou para dizer que ela havia falecido"85 e, por um breve período após a morte de Olive, Douglas foi autorizado a residir no apartamento em Hove. Portanto, além da forma teatral, o cenário é outro aspecto contrastante em relação às peças anteriores de Kilroy.

O tempo cênico descrito nas rubricas refere-se ao ano de 1944, ou seja, um ano antes da morte do protagonista. Mais especificamente, a ação se passa alguns dias antes e, na segunda metade do monólogo, após a morte de Olive. No início, Kilroy indica nas rubricas o som de bombas e a personagem Douglas comenta sobre um abrigo, em claras alusões à Segunda Guerra Mundial. Uma possível hipótese para a inclusão de tais alusões seria a relevância do período na vida do autor, com apenas 10 anos na época. Além disso, vale lembrar que Kilroy também abordou a temática em Double Cross (1986), The Madame MacAdam Travelling Theatre (1992) e em Christ Deliver Us! (2010).

O título My Scandalous Life remete, a princípio, a todo escândalo em torno da relação entre Douglas e Wilde, as acusações, a prisão e todas as consequências geradas a partir de então. Douglas Murray relata vários episódios que chamaram a atenção para a figura de Lord Alfred Douglas, como processos judiciais e discussões em locais públicos, principalmente entre Oscar e Douglas. O biógrafo associa algumas discussões e escândalos às frustrações de Douglas, relatando que muitos amigos próximos e sua família estavam ficando preocupados com seu desinteresse em procurar um emprego. Segundo Murray, "ele discutia frequentemente com Wilde e suas brigas eram

\footnotetext{
85 "On 11 February 1944 Douglas spent several hours with his wife, holding her hand as she lay semiconscious in bed. The next morning Olive's maid telephoned to tell him that his wife had died." (pp. 321-322)
} 
às vezes selvagemente cruéis - causadas, pelo menos em parte, pela frustração de Douglas." ${ }^{, 86}$

Logo após a morte de Wilde, Douglas renunciou à homossexualidade, converteu-se ao Catolicismo, casou-se com Olive Custance e teve um filho, Raymond Douglas. Enfim, uma vida aparentemente normal e livre de escândalos. Porém, ao acompanhar o relato do protagonista, percebemos que a normalidade é apenas uma aparência, pois se trata de uma vida repleta de frustrações e tragédias pessoais. Richard Ellman (1988) apresenta de forma sucinta, no epílogo, os principais episódios da vida de Bosie após a morte de Wilde, principalmente aqueles relacionados com escândalos envolvendo Ross. Ellmann relata que

Ross sentiu-se na obrigação de publicar De Profundis com alguns cortes, e a edição de 1905 omitiu todas as referências a Douglas. Mas estava claro que Douglas havia sido um amor fatal. Uma vaga referência a esse efeito no livro de Arthur Ransome sobre Wilde em 1912 fez Douglas processá-lo por difamação. [...] Ross agora sentia que devia revelar os trechos omitidos de De Profundis, e a pedido do advogado de Ransome, a carta inteira foi lida no tribunal. Douglas estava entre as testemunhas na época, mas saiu durante a leitura. Ele não suportaria ouvir Wilde referir-se ao seu verso como estudantil, à sua estatura como baixa, ao seu caráter como parasita, à sua natureza como superficial. Poucos meses depois, ele tinha sua resposta pronta em Oscar Wilde e Eu. Douglas rejeitou o livro mais tarde [...] Douglas passou, à maneira de seu pai, a escrever cartas atacando Ross aos amigos do mesmo, até que a pressão tornou-se tão grande que Ross, assim como Wilde antes dele, teve que processá-lo por calúnia. [...] Douglas encontrou outros alvos: por uma calúnia contra Winston Churchill ele foi enviado a Wormwood Scrubs por seis meses. [...] No final dos anos 20 ele começou a mudar sua visão sobre Wilde. Na época em que ele escreveu sua Autobiografia (1928), ele havia se tornado um católico ardente, e apesar de seu casamento ter acabado num divórcio previsível, ele não tinha, ou disse que não tinha retomado práticas homossexuais. ${ }^{87}$

\footnotetext{
86 “[...] many of Douglas's close friends and family were becoming worried about his lack of intention to look for a job. He was arguing frequently with Wilde and their quarrels were at times savagely bitter - caused, at least in part, by Douglas's frustration." (p.51)

87 "Ross felt bound to publish it (De Profundis) in an abridged form, and the 1905 edition omitted all reference to Douglas. But it was clear that Douglas had been an amour fatale. A vague reference to this effect in Arthur Ransome's book on Wilde in 1912 made Douglas sue for libel. [...] Ross now felt he must disclose the missing portions of De Profundis, and at the request of Ransome's counsel, the whole letter was read out in court. Douglas was in the witness box at
} 
O efeito irônico fica evidente na abertura da peça, visto que o espectador com algum conhecimento prévio certamente associaria Lord Alfred Douglas a uma figura jovem, sensual e nada religiosa. Até mesmo o espectador ou leitor, cuja única referência fosse o título do espetáculo, ou seja, sem nenhuma informação biográfica adicional, ficaria surpreso com o início da peça, ao ouvir uma voz trêmula, certamente de um idoso, na escuridão cantando Jesu, Joy of Man's Desiring, de Bach. Tais escolhas de Kilroy, provavelmente, têm o objetivo de sugerir traços biográficos, como a já citada conversão ao Catolicismo e o arrependimento em relação aos escândalos vividos e provocados por ele. Na sequência, Douglas dirige-se ao público informando a que veio:

Oscar Wilde, você disse? É só isso que é do interesse de todos? Wilde-Wilde-Wilde-Wilde! Pelo amor de Deus, tudo isso foi há quase cinquenta anos. É minha vida agora. Por que vocês não perguntam sobre as pessoas que realmente tiveram importância em minha vida? Hein? Meu querido filho, Raymond. Minha mãe, minha esposa, Olive. ${ }^{88}$

Nas falas iniciais, o protagonista avisa que não quer falar sobre Oscar Wilde; no entanto, em vários momentos, retoma o assunto demonstrando ser inevitável dissociar o relato de sua vida da figura de Wilde. Em diversos

the time, but left during the reading. He could not bear to listen to Wilde's reference to his verse as undergraduate, to his stature as low, to his disposition as sponging, to his nature as shallow. Within months he had got his reply ready in Oscar Wilde and Myself. Douglas disclaimed the book later [...] Douglas now began, in his father's manner, to write letters attacking Ross to Ross's friends, until the pressure became so great that Ross, as Wilde before him, had to sue for libel. [...] Douglas found other targets: for a criminal libel of Winston Churchill he was sent to Wormwood Scrubs for six months. [...] In the late 1920s he began to change his view about Wilde. By the time he wrote his Autobiography (1928), he had become ardently Catholic, and although his marriage ended in a predictable divorce, he had not, or said he had not, resumed homosexual practices." (ELLMANN, 1988, p.587)

88 "Oscar Wilde, did you say? That's all you lot ever ask about. Wilde-Wilde-Wilde-Wilde! For Heaven's sake, all that was nearly fifty years ago. It's my life now. Why don't you ask about the people who have really mattered in my life? Eh? My darling son, Raymond. My mother. My wife, Olive." (p.9) 
trechos, Douglas fala de forma similar a Wilde, preocupando-se com as palavras utilizadas ("A propósito, que palavra terrivelmente vulgar é esta. Folia!"89), com uma postura aristocrática, típica de um dandy, e tenta imitar o ex-amante, por exemplo, ao escrever e traduzir poemas e outras obras literárias.

Dentre as referências a Wilde, podemos destacar o trecho em que ele comenta que ambos tiveram um fim semelhante, visto que ambos dependeram de uma insignificante mesada paga pelas ex-esposas (pp.11-12). Em sua biografia, Douglas Murray comenta sobre o período após a prisão de Oscar, quando ambos dependiam financeiramente de outras pessoas com a condição de não se encontrarem mais, no entanto tal situação não impediu o reencontro: "Ambos estavam vivendo das pensões de outras pessoas, Douglas de sua mãe, Wilde de sua esposa, e o fato de que poderiam ser canceladas a qualquer momento deu aos encontros uma maior sensação de risco e emoção furtiva."90

My Scandalous Life pode ser considerada a contraparte de The Secret Fall of Constance Wilde, uma das peças mais importantes de Kilroy, visto que, além de retomar uma das personagens, também apresenta alguns elementos em comum, tais como o relacionamento problemático com a figura paterna e uma visão pessimista do casamento: "De fato, eu acho o casamento uma das mais terríveis instituições na história humana"91, diz Douglas. Vemos que, da mesma forma como Wilde chamava Constance de irmã em The Secret Fall,

\footnotetext{
89 "What an appallingly vulgar word that is, by the way. Fling!" (p.23)

90 "Both men were living on allowances from other people, Douglas from his mother, Wilde from his wife, and the fact that either might be cancelled at any moment gave their reunion an added sense of risk and furtive excitement." (p.105)

91 "Actually, I think marriage may be one of the most dreadful institutions in human history". (p.10)
} 
Douglas afirma que Olive e ele ainda estariam juntos se não tivessem se casado, se tivessem sido como irmão e irmã. (p.22)

The Secret Fall of Constance Wilde, em suas últimas cenas, apresenta o jovem Douglas relatando ao público como viveu após a morte de Constance e Oscar "Casado, ajuizado [...] Ser humano perfeitamente normal novamente. Não como aquele horrível bostinha que eu costumava ser. Absolutamente não. Não. Normal! Normal! Normal!"92 E é justamente este Douglas "normal" e mais velho o protagonista da peça de 2004.

Além disso, no monólogo, ao referir-se a Wilde e ao Destino, Douglas faz uma alusão ao grande círculo do Destino de The Secret Fall of Constance Wilde: "Círculos, tudo circulando e circulando de volta a tudo" Posteriormente, Douglas comenta que, da mesma forma como ocorreu a Wilde na prisão, Cristo apareceu a ele, no entanto não era o Cristo crucificado do Gólgota, mas o garoto de 12 anos que surpreendeu os sábios no Templo de Jerusalém. A imagem de Cristo representa uma oposição ou um espelho invertido, visto que em The Secret Fall temos um Douglas jovem e a visão de Cristo maduro (inclusive, durante a simulação da prisão de Wilde, a personagem Douglas entra em cena representando Cristo). Em contrapartida, em My Scandalous Life, há um Douglas idoso em oposição à figura de Cristo ainda criança, simbolizando a inocência.

Há, ainda, outra referência à peça anterior, quando Douglas observa que o detetive que contratara para seguir Colonel Custance chamava-se Littlechild (Kilroy, ironicamente, muda o nome), o mesmo nome do detetive contratado por seu pai, Lord Queensberry, a fim de espionar Wilde. Ellmann (1988)

\footnotetext{
92 "Married, settled down [...] Perfectly normal human being once more. Not like that dreadful little shit I used to be. Absolutely not. No. Normal! Normal! Normal!" (pp.64-65)

93 "Circles, everything circling and circling back to everything else!" (p.12)
} 
comenta sobre esse detetive: "Ao mesmo tempo, detetives particulares estavam investigando em Londres, e um, um homem chamado Littlejohn, [...] no apartamento havia uma espécie de caixa, contendo os nomes e endereços de rapazes com quem Wilde dormiu."94 Segundo o protagonista Douglas, tal figura remetia à "velha Figura do Destino", expressão usada em The Secret Fall, que simboliza as forças do Destino que fizeram as três personagens (Constance, Oscar e Douglas) de marionetes, intensificando suas tragédias pessoais:

\begin{abstract}
Eu havia contratado um detetive particular, veja, um bisbilhoteiro, um Sr Littlechild. Littlechild - Littlechild, esse nome. Não podia ser! Impossível, com certeza! Você não pode ser o mesmo Sr Littlechild! O mesmo o quê, senhor?

O mesmo Littlechild, o sujeito que desenterrou a sujeira sobre Oscar Wilde para meu pai o Marquês de Queensberry? Há muitos anos. Você é muito jovem. Mesma família, senhor. Família dos Littlechilds. Bem, bem. Todos no negócio de bisbilhotar. Notável, devo dizer. Confesso que olhei para ele por um longo tempo. Em toda sua banalidade, em toda sua medonha normalidade, meu cão de caça, capa surrada, o destino, meu cão de caça espinhento trazia algo da velha figura do Destino. O que é isso, senhor? Nada, eu disse, nada. Estava pensando em Oscar. ${ }^{95}$
\end{abstract}

Observa-se, portanto, que o fato do dramaturgo retomar a personagem e alguns temas e aspectos de The Secret Fall sugere uma continuidade em sua obra ou, talvez, um espelho entre as peças, tal como ocorre entre a primeira e a segunda parte de Double Cross, analisada no primeiro capítulo.

\footnotetext{
94 "At the same time private detectives were looking about London, and one, a man named Littlejohn, [...] in the flat was a kind of postbox, containing the names and addresses of boys with whom Wilde consorted." (p.441)

95 "I had employed a private detective, you see, a snoop, one Mr Littlechild. Littlechild Littlechild, that name. It couldn't be! Impossible, surely! You can't be the same Mr Littlechild! Same what, sir?

Same Mr Littlechild, the chap who dug up the dirt on Oscar Wilde for my father the Marquess of Queensberry? Donkey's years ago. You're far too young. Same family, sir. Family of Littlechilds. Well-well. All in the snoop business. Remarkable, I must say. I confess I looked at him a long while. In all his banality, in all his quite dreadful ordinariness, my sleuth, battered raincoat, the lot, my pimpled blood-hound carried something of the old figure of Fate. What is it, sir? Nothing, I said, nothing. I was thinking, you see. Of Oscar." (pp.18-19)
} 
Olive é descrita por Douglas como uma mulher masculinizada, o que condiz com os relatos de Douglas Murray, ao afirmar que "Olive era linda como um menino e feminina, mas não como uma menininha. Douglas relatou que fora 'amor à primeira vista' para ambos"96. O biógrafo comenta que a atração de Douglas por Olive confirmou uma suspeita guardada por vários anos, porém declarada corajosamente em sua autobiografia: "Eu creio que quase todo mundo é mais ou menos bissexual" 97 . Na peça, Douglas revela: "O que eu quis dizer é que Olive e eu fomos atraídos pela sombra sexual do outro, ela pelo meu lado feminino e eu pelo seu lado masculino. Eu entendo isso agora. Tarde demais, sim, eu sei, eu sei. [...] ela me chamava de seu menino-menina"98. Para a personagem, o motivo dessa masculinização é o fato, biograficamente comprovado, de que o pai de Olive Custance gostaria de ter um filho e não uma filha: "Ele sempre quis ter um filho, Olive disse. Ela gastou toda a sua infância tentando ser um garoto, mantendo seu cabelo bem curto, fazendo musculação, cuspindo e xingando e todo o resto. Tentando impressionar o Papai." ${ }^{99}$ Thomas Kilroy, apropriando-se dos registros biográficos, constrói outra oposição (poderíamos também chamar de "espelho" ou "duplo") por meio do discurso de Douglas.

Segundo o protagonista, Olive odiava o filho Raymond: "Eu nunca mais quero vê-lo novamente, ela gritou. Não-não, você não deve dizer isso, querida, ele é nosso menino. Não me importo, ela chorou, eu o odeio, odeio, lágrimas

\footnotetext{
96 "Olive was pretty in a boyish way, feminine but not girly. Douglas reported that it was 'love at first sight' for both of them." (p.124)

97 "And his attraction to her confirmed in him a suspicion he had long harboured, but stated boldly in 1929: 'I believe that almost everyone is more or less bisexual."' (p.124)

98 "What I mean is that Olive and I were attracted to each other's sexual shadow, she to my feminine side and I to her masculine. I understand it now. Too late, yes, I know, know. [...] she called me her boy-girl." (p.22)

99 "He had always wanted a son, Olive said. She spent her own childhood trying to be a boy, cutting her hair, building muscle, spitting and cursing and all the rest of it. Trying to impress Daddy". (p.13).
} 
escorrendo em seu rosto"100 ou "Ela odiava Raymond! Como ela o odiava! Odiava ter dado à luz a ele, detestava vê-lo tornar-se - vê-lo caindo - na loucura. Ele é seu, ela gritou. Leve-o! Ele não é meu!" ${ }^{101}$ De acordo com Murray, Douglas achava Olive uma mãe ausente, que falava com frequência que odiava o filho e desejava que ele nunca tivesse nascido (p.196). A rejeição sofrida por Raymond consta nas biografias consultadas somente em comentários breves e superficiais. Entretanto, conforme observamos nos trechos transcritos acima, Kilroy explora e acentua essa rejeição ao acrescentar no monólogo discussões e desabafos ficcionais de Olive.

O modo como a personagem conduz o monólogo nos leva a acreditar que a doença mental de Raymond, de fato, é fruto das ações do avô materno Colonel Frederic Custance e de Robert Ross, amigo íntimo de Wilde, "Sumo sacerdote do culto a Wilde" (p.14), porém o próprio Douglas reconhece que estava mentindo: "Eles nunca estiveram juntos, Custance e Ross, exceto em minha mentira maluca. Eles não tiveram culpa da doença de meu filho, Raymond. A loucura de Raymond vem da minha própria carne e sangue. Ele está em mim e eu estou nele"102. Observa-se que Douglas, ao mesmo tempo em que busca uma espécie de purificação revelando vários detalhes íntimos de sua vida, também tenta fugir da triste realidade, a loucura do filho, e de sua culpa pela maldição familiar.

\footnotetext{
100 "I never wish to see him again, she screamed. No-no, you mustn't say that, dear, he's our boy. Don't care, she cried, hate him, hate him, tears streaming down her face" (p.12)

101 "She hated Raymond! How she hated him! Hated giving birth to him, hated watching him become - seeing him sink into - madness. He is yours, she yelled at me. Take him! He's not mine!" (p.22)

102 "They never belonged together, Custance and Ross, except in my mad lying. They had no part in the sickness of my son, Raymond. Raymond's madness is of my own flesh and blood. He is in me and I am in him." (p. 27)
} 
Outra observação importante refere-se ao fato de Custance e Ross nunca terem se unido para atacar Douglas e sua família; entretanto, vários episódios relatados pela personagem condizem com os registros biográficos. Por exemplo, em relação ao pai de Olive, Colonel Custance, citado várias vezes no monólogo, Douglas Murray relata as ações judiciais para conseguir a guarda do neto. O biógrafo comenta que, após a segunda vez em que Olive se separou de Douglas,

\begin{abstract}
Mais uma vez ela voltou para o pai, a quem Douglas considerava seu inimigo tanto quanto Ross. Olive estava presa entre seu marido, a quem amava, seu pai, a quem amava, e seu filho, que era, como ela, o objeto da disputa. [...] Mas a verdadeira vítima da guerra entre Douglas e Custance era Raymond, na época com treze anos. A justiça tinha ordenado que a guarda do menino deveria ser dividida entre o pai e o avô, o que Douglas achou impossível aceitar [...] Era o pai de Olive que estava tomando as decisões por ela e era ele quem queria Raymond. ${ }^{103}$
\end{abstract}

Ao construir e apresentar a narrativa a partir da memória de Douglas, Kilroy acrescenta lembranças distorcidas e afirmações assumidamente inverídicas, como a aliança entre Ross e Custance. Provavelmente, o dramaturgo tenha se pautado nos registros, como o transcrito anteriormente, que apontam Custance e Ross como os maiores inimigos de Douglas, considerando-os bases biográficas para os devaneios ficcionais da personagem.

\footnotetext{
103 "Once again she returned to her father, whom Douglas considered as much his enemy as Ross. For her part Olive was caught between her husband, whom she loved, her father, whom she loved, and her son, who was, like her, the object of the quarrel. [...] But the real victim of the war between Douglas and Custance was the now thirteen-year-old Raymond. The courts had ordered that the boy's time should be shared between his father and his grandfather, which Douglas found impossible to accept [...] it was Olive's father who was making the decisions for her and it was he who wanted Raymond." (pp.194-195)
} 
O episódio do sequestro de Raymond, citado na peça, demonstra a obsessão de Custance pelo neto, principalmente após a morte da esposa em 1908 e devido ao desejo de ter um filho. Douglas Murray relata que

\begin{abstract}
Um dia, Raymond saiu para pescar normalmente. Ele não voltou. [...] por dois dias Douglas achou que seu filho estava morto. Então ele recebeu um telegrama de Olive - para lhe contar que Raymond estava com ela e o Colonel Custance em Norfolk. Custance, através de seu advogado George Lewis, havia contratado um detetive particular para ir à Escócia ao hotel onde Raymond e o pai estavam, sequestrar 0 garoto e trazê-lo de volta à jurisdição dos tribunais ingleses. ${ }^{104}$
\end{abstract}

No monólogo, Douglas afirma também que o sogro, assim como a maioria dos ingleses, nutria um sentimento de ódio pelos católicos ("Quando me tornei católico, ela me acompanhou a Roma. Para a fúria de seu pai, o Coronel, que odiava tudo que fosse romano, particularmente sacerdotes." ${ }^{105}$ ). De acordo com Douglas Murray, Custance "conservava uma amargura particularmente irracional contra o Catolicismo Romano"106 porque um dos maiores desgostos em sua vida fora sua irmã que abandonara a família para casar-se com um católico.

A única e breve referência à Eileen histórica existente nas biografias consultadas não nos informa sobre sua personalidade nem sobre seu relacionamento com Raymond, apenas sobre sua aparência. Segundo os registros biográficos, após a alta de Raymond no St Andrew's Hospital, ele passou a morar com o pai, no apartamento da mãe recém-falecida, e a criada

104 "One day, Raymond set off fishing as normal. He did not return. [...] For two days Douglas thought his son was dead. Then he received a telegram from Olive - to tell him that Raymond was with her and Colonel Custance in Norfolk. Custance, through his solicitor George Lewis, had hired a private detective to go to Scotland to the hotel where Raymond and his father were still staying, kidnap the boy and bring him back within the jurisdiction of the English courts." (p.213)

105 "When I became a Catholic she followed me to Rome. Much to the fury of her Daddy the Colonel who hated everything Roman, particularly priests" (p.21)

106 "reserved a particularly irrational bitterness for Roman Catholicism" (MURRAY, 2000, p.161) 
Eileen, responsável por cuidar dele. Murray comenta que ela foi descrita pelo jovem ator Donald Sinden (citado na peça como um dos jovens visitantes de Douglas) como "uma enorme górgona ${ }^{107}$, com quadris largos, seios volumosos até a cintura, ombros caídos e uma cabeça grande com uma franja de cabelo preto ensebado, mas quase careca na parte superior." 108 Entretanto, Kilroy encontra nessa lacuna biográfica uma excelente oportunidade para criar uma personagem muito interessante que, apesar de não falar uma palavra sequer ao longo da peça, é fundamental para o desenvolvimento da mesma, principalmente em seus embates com Raymond e no desfecho do monólogo, revelando a gravidade da doença do único descendente de Douglas.

A personagem Eileen, ao trazer chá, pães e tortas (p.23), também dá a deixa para que Douglas comente sobre seus frequentes visitantes que the faziam companhia durante as tardes, jovens escritores e admiradores. Douglas Murray comenta sobre as novas amizades de Bosie: "Douglas estava fazendo novos amigos e à medida que envelhecia alguns jovens escritores se interessavam por ele"109.

Outro aspecto relevante no monólogo é a relação que Kilroy constrói entre a inocência e a corrupção do ser humano. De acordo com José Lanters, no artigo Impossible Promise: The Child and the Androgyne in Thomas Kilroy's The Secret Fall of Constance Wilde and My Scandalous Life (2010, p.279), a relação entre inocência e corrupção toma forma em duas recordações contrastantes que Douglas tem de Raymond quando criança. Na primeira, a

107 Segundo a Mitologia Grega, as Górgonas eram seres monstruosos com cabelos de serpentes e transformavam em pedra aqueles que olhassem diretamente em seus olhos. Eram três: as imortais Esteno e Euríale, e a mortal Medusa.

108 "a vast gorgon of a woman, with wide hips, pendulous breasts at her waistline, sloping shoulders and a large head with a fringe of mangy black hair, but nearly bald on top." ( pp.322323)

109 "Douglas was making new friends and as he grew older some younger writers became interested in him." (p.255) 
criança inocente ocupa um cenário semelhante ao Éden: "Uma criança tão linda, brincando na grama na Fazenda Aston, Olive debruçada sobre ele como um pássaro branco, o rio Avon fluindo continuamente, tudo pulsando com vida. Eu estava tão feliz, então, tão feliz." ${ }^{110}$ Tais recordações durante a infância de Raymond constam na biografia: "Os anos da infância de Raymond foram os mais felizes do casamento de Douglas. Ele não só estava apaixonado por sua esposa, como também era uma pai adorável. [...] Era uma breve caminhada para o rio Avon, [...] Douglas estava idilicamente feliz."111

Em contrapartida, na segunda memória, o cenário é angustiante: "o verão fervendo lá fora, as árvores pesadas com calor e crescimento, o jardim de cores violentas e além, o rio - [...] a água como metal pesado, fundido entre o verde"112 . O que, na primeira recordação, era o símbolo da inocência infantil, torna-se uma fera, um monstro: "O menino-rato avançou através da grama como se através de um elemento a que estava familiarizado. [...] ele levantou uma tesoura de jardim aberta e atacou as costas vulneráveis de sua mãe."113 Douglas, nessa recordação, corre para salvar sua esposa de seu filho violento, no entanto a encontra carregando uma criança adormecida, com seus braços e pernas em perfeita paz e o rosto no ombro da mãe. De acordo com Lanters, a cena sugere que tudo foi uma projeção da própria mente de Douglas, já com

\footnotetext{
110 "Such a beautiful child, playing on the grass at Aston Farm, Olive arched above him like a white bird, the Avon flowing steadily beyond them, all pulsing with life. I was so happy then, so happy" (p.14)

111 "The years of Raymond's baby and childhood were the happiest of Douglas's married life. Not only was he in love with his wife, he was an adoring father. [...] It was a short walk to the river Avon, [...] Douglas was idyllically happy." (p.135)

112 "the summer boiling away outside the window, the trees heavy with heat and growh, the garden raging in colour and beyond, the river $-[\ldots]$ the water like heavy, molten metal between the greenery" (p.32)

113 "The rat-boy advanced through the grass as through his familiar element. [...] he lifted up an open, pronged shears and lunged at his mother's vulnerable back." (pp.33-34)
} 
problemas psicológicos. Da mesma forma, essa cena pode ser considerada uma premonição do triste destino de Raymond.

A imagem da mãe e da criança adormecida nas recordações de Douglas pode ser relacionada a uma das imagens finais da peça, quando Eileen, a empregada irlandesa, carrega Raymond já adulto, como se carregasse uma marionete. Relacionando essa imagem às marionetes de The Secret Fall of Constance Wilde, Lanters afirma:

Como as marionetes simbólicas do pai e filhos em The Secret Fall of Constance Wilde, Raymond e Eileen, em seus papéis mudos, assumem qualidades simbólicas como a mãe protetora/destruidora e a criança inocente/deteriorada, nos quais eles são reunidos por Douglas como o pai amoroso/monstruoso. ${ }^{114}$

O comentário anterior nos leva a refletir sobre a exploração do "duplo" na peça, diante das várias possibilidades de leitura, por exemplo, em relação ao protagonista, que teve uma imagem construída antes da morte de Wilde e, posteriormente, criou um novo Douglas, casado e católico. Além disso, temos Raymond, que representa a criança inocente e, ao mesmo tempo, o monstro violento cheirando a urina (p.13).

O jardim é um símbolo explorado no monólogo em diversos trechos, principalmente nas duas lembranças contrastantes de Douglas, mencionadas anteriormente; nos momentos que antecedem a morte de Olive ("Eu estou indo para o jardim com Raymond. Essa foi a última coisa coerente que ela me disse. Se você pode chamar isso de coerente. Indo para o jardim com Raymond.

\footnotetext{
114 "Like the symbolic puppets of the father and children in The Secret Fall of Constance Wilde, Raymond and Eileen, in their mute roles, take on symbolic qualities as the protective/destructive mother and the innocent/damaged child, in which they are joined by Douglas as the loving/monstrous father." (2010, p.281)
} 
Imagine!"115); e no desfecho da peça, quando Douglas fala: "Raymond, ele está me chamando de dentro de sua loucura. Me chamando do jardim do caos"116 Dessa forma, o jardim representa a própria loucura, do filho e do pai. De modo geral, o Jardim simboliza o Paraíso, ou seja, um lugar perfeito onde não há doenças, nem maldições. Tal significado produz um efeito contraditório, visto que, na maioria das vezes em que o termo "jardim" é citado, está relacionado à morte, à loucura e ao caos. Todavia, essa relação torna-se coerente ao lembrar que Kilroy, a princípio, escrevera uma peça para a rádio irlandesa denominada In the Garden of the Asylum, justamente o jardim do Hospital para Insanos St Andrew's, em Northampton, um local onde a loucura e o caos mental estavam presentes permanentemente.

Um motivo apontado, no monólogo, como desencadeador da loucura de Raymond é a proibição de seu casamento com Gladys, o que condiz com os registros biográficos que relatam que, em 1926, Raymond anunciou que desejava se casar com uma garota de vinte e três anos proveniente de família nobre chamada Gladys Lacey, incidente que aproximou Douglas e Olive novamente, visto que nada os deixariam mais felizes do que a ideia de Raymond ter um relacionamento familiar normal. De acordo com Douglas Murray, quando Olive e Douglas investigaram a vida da moça,

\footnotetext{
Eles descobriram que ela era seis ou sete anos mais velha do que Raymond, que havia sido noiva e vivido com outro homem por três anos, que o pai dela era um verdureiro e a mãe cuidava de um pub. [...] o colapso dos planos de casamento abalou o equilíbrio de Raymond, e em Dinan ele teve uma espécie de distúrbio mental e tornou-se violento. [...] Em 26 de agosto de 1927 ele foi enviado ao Hospital St Andrew, Northampton, um hospital psiquiátrico, onde foi
}

\footnotetext{
115 "I am going into the garden with Raymond. That's the last coherent thing she said to me. If you can call that coherent. Going into the garden with Raymond. Imagine!" (p.21)

116 "He is calling to me, Raymond, from inside his madness. Calling to me from the garden of chaos." (p.37)
} 
diagnosticado como um paciente esquizo-afetivo e, exceto por alguns breves intervalos, Raymond permaneceu lá pelo resto de sua vida. ${ }^{117}$

Da mesma forma que o biógrafo relata que o diagnóstico de esquizofrenia deu-se após a proibição do relacionamento com Gladys, Douglas, no monólogo, aponta o fato como desencadeador desse agravamento quando pergunta "O que nós matamos nele, Olive, a mamãe e eu, quando o proibimos de ver sua Gladys?" ${ }^{118}$ Nesse aspecto específico, há uma grande relação intertextual entre as biografias e a peça, o que nos leva a deduzir que Kilroy enfatizou esse episódio por ser a loucura uma das principais temáticas do monólogo.

Outra imagem bastante forte construída pelo discurso de Douglas é a impressionante fila de seres fracos e sombrios formando sua linhagem familiar. No trecho abaixo há uma referência à peça Macbeth (Ato IV, Cena 1) de William Shakespeare, quando, durante o encontro com as três feiticeiras, Macbeth vê uma fila formada por oito reis descendentes de Banquo, que segue sua linhagem com os cabelos sujos de sangue:

\begin{abstract}
Uma linhagem de vultos sombrios, sobre os pântanos das terras altas, alguns com os cabelos cobertos de sangue coagulado, alguns com as mãos manchadas de sangue, alguns mutilados e com feridas muito graves e, então, inequivocadamente neste desfile estigeano ${ }^{119}$, um lugar esperando por mim. (Pausa) E um lugar para Raymond! [...] Nós estamos indo tomar nossos lugares, você sabe, ele e eu! Sim, nesta sombria linhagem de vultos no pântano obscuro, a família ensanguentada de Douglas, toda a violência chegando a um fim. ${ }^{120}$
\end{abstract}

\footnotetext{
117 "They discovered that she was six or seven years older than Raymond, that she had been engaged to and living with another man for three years, that her father was a greengrocer and that her mother ran a pub. [...] The collapse of his marriage plans tipped the balance in Raymond, and in Dinan he had some kind of a brainstorm and became violent. [...] On 26 August 1927 he was sent to St Andrew's Hospital, Northampton, a psychiatric home. There he was certified as a schizo-affective patient and, except for a couple of brief intervals, Raymond stayed there for the rest of his life." (pp. 265-266)

118 "What did we kill in him, Olive, Mother and I, when we forbade him to see his Gladys?" (p.36)

119 Referente ao Rio Estige: segundo a Mitologia Grega, um dos rios do Hades, a terra dos mortos.

120 "A line of dim figures out of a mist, upon the Highland moors, some blood-boltered some with bloodstained hands, some hacked with the most grievous wounds and, then, unmistakably in
} 
Essa impressionante descrição sugere todo o sofrimento vivido $e$ causado por Douglas e sua família, desde a tragédia na vida de Constance e seus filhos, Cyril e Vyvyan, passando pela decadência moral, artística e financeira de Wilde, as frustrações da esposa Olive e, principalmente, a doença mental de Raymond, um dos motivos do fim dessa terrível linhagem familiar, pois não deixara herdeiros.

Como vimos nas peças anteriores, os traços épicos são evidentes também em My Scandalous Life, visto que possui forma e tema épicos por natureza, pois além de ser um monólogo, faz referência a uma figura histórica, constituindo uma representação secundária de algo exterior à peça. Por ser um monólogo, há a ruptura de uma regra essencial do drama, o domínio absoluto do diálogo, que é o seu suporte. Segundo Szondi, "da possibilidade do diálogo depende a possibilidade do drama." (2001, p.34)

Observamos que a personagem Lord Alfred Douglas dirige-se ao público durante a peça inteira, o que, segundo Anatol Rosenfeld (2006), é um "sintoma de tendência épica", pois não há uma perspectiva de ilusão cênica; ao contrário, a personagem rompe a quarta parede e, como um porta-voz do autor que escolheu os fatos a serem narrados, relata sua história. Como exemplo, é válido citar o momento, no início do monólogo, em que ele pergunta ao público se gostaria de ouvir alguns de seus belos poemas, segundo ele, os melhores sonetos desde Shakespeare: "Gostariam de ouvir alguns dos meus poemas?

this stygian parade, a place waiting for myself. (Pause) And a place for Raymond! [...] We're are going to take our places, you know, he and I! Yes, in that dim line of figures on the darkened moor, the bloodied family of Douglas, all violence come to an end." (pp.35-37) 
Não? Não? Não. Eu não acho que este seja o momento apropriado para isso" ${ }^{121}$

My Scandalous Life também apresenta uma descontinuidade temporal, visto que a peça é dividida em duas partes, antes e depois da morte de Olive (precisamente, no dia 15 de fevereiro de 1944). O leitor/espectador percebe essa quebra temporal a partir do próprio relato de Douglas que, no início do monólogo, comenta: "Minha esposa, Olive. Na verdade, ela está morrendo lá em cima agora, pobre e velha Olive. É por isso que estou aqui em seu apartamento"122; após a breve pausa que separa os dois momentos, fala: "Suponho que você tenha ouvido as notícias? Olive. Morreu há três dias. 12 de fevereiro de 1944"123. Retomando Szondi, "a frase (pronunciada ou não) 'deixemos passar agora três anos' pressupõe o eu-épico" (p.33), pois tal quebra representa a interferência de um autor/narrador.

Dentre algumas conclusões parciais, podemos afirmar que, em My Scandalous Life, ocorreu o processo de apropriação dos registros históricos e biográficos a fim de recuperar a voz reprimida de Lord Alfred Douglas, de recontar um período obscuro de sua vida, reinventando sua voz. Dessa forma, Kilroy realizou a transposição para o palco de modo reelaborado, incluindo na narrativa alguns fatos inverídicos, como a aliança entre Ross e Custance para atacar Douglas, e lembranças distorcidas, como a agressão de Raymond contra Olive no jardim.

Constatou-se que My Scandalous Life foge das características da maioria das peças de Thomas Kilroy, principalmente por ser um monólogo e

\footnotetext{
121 "Would you care to hear some of my poems? No? No? No. I don't suppose this is the appropriate time for that." (p.10)

${ }_{122}$ "My wife, Olive. Actually she's dying upstairs just now, poor old Olive. That's why l'm here in her flat."(p.9)

123 "Suppose you've heard the news? Olive. Died three days ago. February 12th, 1944." (p.21).
} 
pelo cenário simples e sem grandes artifícios cênicos. Além disso, verificou-se uma grande intertextualidade entre a peça analisada e The Secret Fall of Constance Wilde, por meio da retomada da personagem Douglas e da presença de temas em comum, tais como o conflito com a figura paterna ou a visão pessimista em relação ao casamento. Podemos, inclusive, considerar $M y$ Scandalous Life a contraparte de The Secret Fall, reconhecendo uma relação de continuidade na obra do dramaturgo irlandês.

O efeito irônico, cujo início dá-se nos primeiros minutos da peça, permeia todo o monólogo, principalmente nos momentos em que Douglas apresenta uma postura religiosa em contraste com a vida trágica e escandalosa que levou. É importante salientar ainda que a vida aparentemente normal de Lord Alfred Douglas (homem casado, católico e pai de família) após a morte de Wilde não foi nada normal devido não só às consequências de seu comportamento na juventude, mas também às fatalidades do grande círculo do Destino. 


\section{CONSIDERAÇÕES FINAIS}

A partir da análise de Double Cross, The Secret Fall of Constance Wilde e My Scandalous Life, foi realizado o estudo da apropriação e transposição de biografias para o palco. Ao longo da pesquisa, verificamos nas peças possíveis registros biográficos transpostos e os recursos teatrais utilizados para sugerilos, bem como analisamos de que forma deu-se o processo de apropriação e transposição das biografias para o teatro, refletindo sobre as escolhas do autor. Além disso, a análise das lacunas biográficas buscou compreender e refletir sobre os mecanismos de transposição de um gênero tão específico como a biografia para a linguagem teatral. Por fim, foi realizado o levantamento e a análise das características épicas de cada peça, baseando-nos nas obras Teoria do Drama Moderno (2001), de Peter Szondi, e O Teatro Épico (2006), de Anatol Rosenfeld.

O gênero biográfico possui um caráter híbrido, manifestando características do discurso histórico e da literatura, visto que, de acordo com François Dosse (2009), a biografia se situa na tensão constante entre a vontade de reproduzir um vivido real passado e o polo imaginativo do biógrafo, que deve refazer um universo perdido segundo sua intuição e talento criador.

Para a composição das três peças, Thomas Kilroy realizou procedimentos similares: o autor partiu de uma pesquisa exaustiva, buscando registros biográficos referentes às figuras históricas abordadas, incluindo 
cartas, documentos e biografias. Em fase posterior, o processo de criação foi direcionado pela imaginação do autor, explorando as lacunas biográficas e criando novas situações e personagens, numa "rede histórica de possibilidades irônicas" (KILROY, 1994, p.11), a fim de compor uma obra de arte e não uma mera reprodução dos registros históricos. Houve, portanto, a criação de produtos diferentes daqueles que Ihes serviram como base por meio da teatralização e da utilização de formas e recursos teatrais variados, demonstrando que, para o autor, a preocupação estética é mais relevante do que a correlação entre as peças e os respectivos registros biográficos.

Retomando Leila Perrone-Moisés, podemos dizer que a transposição foi realizada "em termos de reelaboração ilimitada da forma e do sentido, em termos de apropriação livre". (1978, p.60), num processo em que, segundo Hutcheon, os textos-fonte foram interpretados e recriados, o que envolveu, além das demandas do gênero teatral, também "o temperamento e talento do adaptador - e seus intertextos individuais através dos quais foram filtrados os materiais". (2006, p.84)

Ainda em termos teóricos, em Adaptation and Appropriation (2006), Julie Sanders, analisando a apropriação da história, afirma que os motivos pelos quais um autor escolhe fatos e figuras históricas a fim de dramatizá-los podem variar e aponta duas razões recorrentes: em alguns casos, há paralelos e comparações que evocam uma questão contemporânea; em outros, o autor deseja recuperar vozes perdidas ou reprimidas.

Por exemplo, em Double Cross foi verificado que Thomas Kilroy apropriou-se dos registros históricos e biográficos de William Joyce e Brendan Bracken a fim de questionar a estabilidade dos fatos transcorridos e de 
estabelecer paralelos e comparações com uma questão presente na Irlanda dos anos 80: os aspectos negativos do nacionalismo extremo e a reflexão sobre a identidade nacional. Dessa forma, ao abordar o passado, Kilroy ilumina o presente.

Em Double Cross, elaborada especialmente para a Companhia Teatral Field Day a fim de promover um debate sobre poder, identidade, nacionalismo e fascismo, assistimos a várias passagens das vidas de Brendan Bracken e William Joyce, incluindo fatos ocorridos na infância, relacionamentos amorosos e conflitos durante a Segunda Guerra Mundial. Todavia, muitos registros transpostos não são encenados, mas apenas citados e comentados pelos narradores e algumas personagens, produzindo um efeito de distanciamento da ação ao longo da peça.

Como exemplos de criação e teatralização, podemos citar os recursos empregados no cenário (telão e cartazes), os narradores, as personagens Popsie e Erich, e os diálogos entre os protagonistas Bracken e Joyce (visto não existir nenhuma evidência de que tenham se conhecido ou que, ao menos, soubessem da existência um do outro).

Seria pertinente discutir aqui o valor histórico e artístico de Double Cross, partindo do princípio de que certas referências históricas têm determinada vigência. Sabe-se que o intuito principal de Thomas Kilroy foi promover uma reflexão sobre questões presentes na Irlanda dos anos 80 e tanto as referências à Segunda Guerra Mundial quanto as alusões à identidade irlandesa poderiam ser consideradas "datadas". Entretanto, tal "rótulo" não se sustenta diante do grande valor estético da peça, visto que explora a teatralidade ao extremo por meio dos recursos cênicos e de conceitos como o 
duplo e o espelho. Além disso, o enredo de Double Cross oferece ao leitor/espectador as referências necessárias para a compreensão da mesma. Vale salientar que o mesmo pode ser dito em relação a The Secret Fall e My Scandalous Life, cujo valor artístico supera qualquer referência "datada".

Em The Secret Fall of Constance Wilde, Thomas Kilroy apropriou-se dos registros a fim de recuperar vozes reprimidas, de recontar a história de personagens marginalizadas reinventando suas vozes. Constance Wilde, certamente, pode ser considerada uma voz reprimida e marginalizada, visto que geralmente é uma personagem secundária nas biografias e obras ficcionais que abordam a vida de Oscar Wilde.

Nessa peça, o autor escolheu dois fatos ocorridos no final da vida de Constance como ponto de partida de sua jornada secreta: sua recusa aos pedidos de Oscar para ver os dois filhos após a saída da prisão e sua misteriosa queda na casa em Tite Street, The House Beautiful. Além disso, por meio de pesquisa prévia, Kilroy descobriu dois fatos obscuros que o auxiliaram na conexão dos acontecimentos: a prisão do pai de Constance por exposição indecente (o que lhe serviu de base histórica para sugerir o estupro de Constance) e a fascinação de Douglas pelos filhos de Oscar. Dessa forma, todos os fatos e especulações formam um complexo pano de fundo para essa grande tragédia humana.

Foi observado que o autor utilizou recursos teatrais diversos durante 0 processo de apropriação e transposição, tais como Assistentes e Marionetes, numa nítida alusão ao teatro oriental Kabuki e Bunraku. Também foram utilizadas estruturas móveis no cenário como o círculo branco, a escadaria e as 
jaulas, nos quais foram encenados, ou apenas sugeridos, episódios biográficos relevantes como o julgamento de Wilde e a queda de Constance.

Thomas Kilroy não se limitou à mera representação visual do que consta nas biografias e cartas, preferindo reformular o material, acentuando, acrescentando, omitindo e criando. Um excelente exemplo da capacidade de teatralização do dramaturgo é a cena da simulação da queda de Constance em que, ao invés de simplesmente compor uma cena em que a protagonista tropeça no tapete e cai escadaria abaixo (o que seria condizente com os registros biográficos), o dramaturgo optou por uma elaborada coreografia cênica em que Constance grita e luta para não ser arrastada pelas "Figuras do Destino", interpretadas pelos Assistentes.

Apesar de The Secret Fall of Constance Wilde ser, das três peças analisadas, a que mais se baseia nas biografias, visto que as personagens Oscar e Douglas se aproximam bastante das figuras históricas, Constance foi fruto da imaginação de Kilroy, uma Constance indignada e disposta a revisitar os trágicos episódios de sua vida por meio de uma jornada secreta ao passado, a fim de conhecer-se, visto que a personagem não aceita mais ser uma marionete do Destino.

Em My Scandalous Life também houve a apropriação dos registros históricos e biográficos a fim de recuperar a voz reprimida de Lord Alfred Douglas após a morte de Wilde, de recontar um período obscuro de sua vida, reinventando sua voz. Dessa forma, Kilroy realizou a transposição para o palco de modo reelaborado, incluindo na narrativa algumas lembranças distorcidas e fatos inverídicos. 
No monólogo, acompanhamos um outro Lord Alfred Douglas, um homem com setenta e quatro anos lutando para recuperar sua identidade, pois não quer ser conhecido apenas como o amante de Oscar Wilde. Entretanto, apesar da relutância inicial da personagem, constata-se que ele estará perpetuamente ligado à figura de Wilde. Aliás, é necessário ressaltar que a peça surgiu do interesse de Thomas Kilroy pela vida de Douglas após a morte do amante.

Um elemento importante na peça é o efeito irônico que permeia todo o monólogo, principalmente nos momentos em que Douglas apresenta uma postura religiosa em contraste com a vida trágica e escandalosa que levou. Além disso, foi constatado que My Scandalous Life foge das características da maioria das peças de Thomas Kilroy, principalmente por ser um monólogo e pelo cenário simples e sem grandes artifícios cênicos.

Apesar de não ser o objetivo principal da presente dissertação, a análise do épico fez-se necessária devido à grande quantidade de traços épicos presentes nas peças. A princípio, foi realizada uma síntese das características do drama puro aristotélico apontadas por Peter Szondi: o drama é absoluto, ou seja, deve estar desligado de tudo o que lhe é externo; o drama é primário, e não uma representação (secundária) de algo (primário); o dramaturgo está ausente no drama, dessa forma, a fala dramática não é expressão do autor, nem uma alocução dirigida ao público; há o domínio absoluto do diálogo, que é o suporte do drama; por fim, no drama, deve haver uma sequência de presentes absolutos, ou seja, a descontinuidade temporal caracteriza o épico.

As obras analisadas, assim como todas as peças baseadas em registros históricos ou biográficos, são, por natureza, "não-dramáticas", pois fazem 
referência a algo exterior ao drama e são representações secundárias de algo primário. Além dos Narradores em Double Cross, outras personagens (Bracken, Joyce, Lord Castlerosse, Constance, Oscar e Douglas) dirigem-se ao público para narrar ou comentar algo, interrompendo a situação dialógica.

As peças apresentam descontinuidade temporal, por meio do retorno a tempos passados e de comentários antecipando eventos futuros, quebrando a atualidade cênica, visto que toda a ação já aconteceu. Por exemplo, em The Secret Fall of Constance Wilde, temos a descontinuidade temporal devido à jornada secreta ao passado empreendida por Constance e Oscar, e à intervenção dos Assistentes manipulando a história, por meio da pantomima, como se fossem narradores. Em Double Cross, há suspensão da ilusão cênica durante a transformação, no palco, da personagem Bracken em Joyce. Em The Secret Fall, observamos a suspensão na cena em que Oscar e Constance tornam-se mais jovens, com o auxílio dos Assistentes, nos momentos em que as Marionetes e os Assistentes estão em cena, no Leilão "surreal" e na Missa dos Mortos, citando apenas alguns exemplos.

Quanto à estrutura das peças, há pontos em comum: todas possuem duas partes ou, no caso de Double Cross, são duas peças que se complementam; e na temática, visto que todos os protagonistas têm um relacionamento conflituoso com a figura paterna, cujas consequências arrastaram-se da infância até a vida adulta.

Há um fato peculiar presente nas peças abordadas: são as personagens masculinas (Brendan Bracken, William Joyce, Oscar Wilde e Lord Alfred Douglas) que adotam máscaras e criam identidades sexuais, políticas e nacionais por meio da atuação, enquanto as personagens femininas (Popsie, 
Margaret Joyce, Constance Wilde e Eileen), geralmente, mais revelam a realidade do que a inventam.

Thomas Kilroy, estimulado por questões não respondidas na história, explorou, nas três peças, as possibilidades de mudança dos registros biográficos, nos oferecendo registros ficcionais ricos em elementos cênicos e gerando múltiplas leituras. Portanto, não podemos atribuir apenas um valor histórico ou biográfico, mas um grande valor artístico a essas peças que marcaram de forma considerável o teatro contemporâneo irlandês e, talvez, mundial. 


\section{BIBLIOGRAFIA}

AMOR, Anne Clark. Mrs. Oscar Wilde: A Woman of some importance. London: Sidgwick \& Jackson, 1983.

BARROS, Diana Luz Pessoa de; FIORIN, José Luiz. (Orgs.). Dialogismo, polifonia, intertextualidade. São Paulo: EDUSP, 2003.

BENTLEY, Joyce. The importance of being Constance. London: Robert Hale, 1983.

CARVALHAL, Tânia Franco. O próprio e o alheio: ensaios de literatura comparada. São Leopoldo: Editora da Unisinos, 2003.

CHEVALIER, J. e GHEERBRANT, A. Dicionário de Símbolos (mitos, sonhos, costumes, gestos, formas, figuras, cores, números). 12. ed., Rio de Janeiro, José Olympio, 1998.

CHURCHILL, Winston. Memórias da Segunda Guerra Mundial. Ed. Denis Kelly. Trad. Vera Ribeiro. Rio de Janeiro: Nova Fronteira, 1995.

COLE, J. A. Lord Haw Haw and William Joyce: the full story. London: Faber and Faber, 1964.

DEAR, I.C.B.(ed). The Oxford Companion to the Second World War. Oxford: Oxford University Press, 1995.

DOSSE, François. O Desafio Biográfico: Escrever uma vida. Trad. Gilson César Cardoso Souza. São Paulo: Edusp, 2009.

DUBOST, Thierry. The plays of Thomas Kilroy: A critical study. London: Mcfarland \& Co Inc., 2007.

EAGLETON, Terry. St. Oscar. London: Bookmarks, 2004. 
ELLMANN, Richard. Oscar Wilde. New York: Alfred A. Knopf, 1988.

FARNDALE, Nigel. Haw-Haw: The tragedy of William and Margaret Joyce. London: MacMillan, 2005.

GENETTE, Gérard. Palimpsests: Literature in the Second Degree. Trad. Channa Newman and Claude Doubinsky. Nebraska: University of Nebraska Press, 1997.

GOEBBELS, Joseph. Diário: Últimas anotações 1945. Trad. Lya Luft. Rio de Janeiro: Nova Fronteira, 1978.

HARE, David. The Judas Kiss. London: Almeida Th., 1997.

HISGAIL, Fani (org.). Biografia: Sintoma da Cultura. São Paulo: Hacker Editores, Cespuc, 1996.

HOISEL, Evelina. A Escritura Biográfica. São Paulo: Tese FFLCH, 1996.

HOLLAND, Vyvyan. Son of Oscar Wilde. New York: E. P. Dutton, 1954.

HUTCHEON, Linda. A Theory of Adaptation. London: Routledge, 2006.

A Poetics of Postmodernism: History, Theory, Fiction. London: Routledge, 1988.

KAUFMAN, Moises. Gross Indecency: The Three Trials of Oscar Wilde. New York: Vintage Books, 1998.

KENNY, Mary. Germany Calling: a personal biography of William Joyce. New Island, 2003.

KILROY, Thomas. Talbot's Box. Loughcrew: Gallery Press, 1979. . The Big Chapel. London: Faber and Faber, 1986. . The Madame MacAdam Travelling Theatre. London: Methuen, 1991. . The Seagull (After Chekhov). Loughcrew: Gallery Press, 1993. . Double Cross. Loughcrew: Gallery Press, 1994. 
. The O'Neill. Loughcrew: Gallery Press, 1995.

. The Secret Fall of Constance Wilde. Loughcrew: Gallery Press, 1997.

. Tea and Sex and Shakespeare. Loughcrew: Gallery Press, 1998.

. The Death and Resurrection of Mr. Roche. (Revised Edition)

Loughcrew: Gallery Press, 2002.

. Ghosts (After Ibsen). Loughcrew: Gallery Press, 2002.

. The Shape of Metal. Loughcrew: Gallery Press, 2003.

. My Scandalous Life. Loughcrew: Gallery Press, 2004.

. Pirandellos. Loughcrew: Gallery Press, 2007.

. Christ Deliver Us! Loughcrew: Gallery Press, 2010.

$\mathrm{KOCH}$, Ingedore G. Villaça; BENTES, Anna Christina; CAVALCANTE, Mônica M. Intertextualidade: diálogos possíveis. São Paulo: Cortez, 2007.

KRISTEVA, Julia. Introdução à Semanálise. Trad. Lucia Helena França Ferraz. São Paulo: Perspectiva, 2005.

LANTERS, José. "Impossible Promise: The Child and the Androgyne in Thomas Kilroy's The Secret Fall of Constance Wilde and My Scandalous Life". In: Ilha do Desterro, n. 58. Florianópolis, 2010, pp.267-288.

LYSAGHT, Charles Edward. Brendan Bracken. London: Allen Lane, 1979.

MASTERMAN, J. C. The Double-Cross System in the War of 1939 to 1945. New Haven, 1972.

MURRAY, Douglas. Bosie: A Biography of Lord Alfred Douglas. New York: Miramax Books, 2000.

MUTRAN, Munira Hamud. Álbum de Retratos: George Moore, Oscar Wilde e William Butler Yeats no fim do século XIX: um momento cultural. São Paulo: Humanitas/FFLCH/USP: FAPESP, 2002. 
. "Oscar Wilde e o homem fatal". In: Prezado Senhor, Prezada Senhora:

Estudo sobre Cartas. São Paulo: Companhia da Letras, 2000.

NITRINI, Sandra. Literatura comparada: história, teatro e crítica. São Paulo:

EDUSP, 2000.

. "Hugh O'Neill's Splintered Identity". In: Global Ireland: Current

Perspectives on Literature and the Visual Arts. Newcastle: Cambridge Scholars Publishing, 2011.

O'BRIEN, Conor Cruise (abridged by Jim McCue). Edmund Burke. Dublin: New Island Books, 1997.

PAVIS, Patrice. O Teatro no Cruzamento de Culturas. Trad. Nanci Fernandes. São Paulo: Perspectiva, 2008.

. Dicionário de Teatro. Trad. Jacó Guinsburg. São Paulo: Perspectiva, 1999.

PERRONE-MOISÉS, Leyla. Flores na escrivaninha: ensaios. São Paulo: Companhia das Letras, 1990.

. Texto, crítica, escritura. São Paulo: Ática, 1978.

REIMANN, Viktor. The Man who Created Hitler: Joseph Goebbels. London: Sphere Books, 1979.

ROSENFELD, Anatol. O Teatro Épico. 5.ed. São Paulo: Perspectiva, 2006.

SANDERS, Julie. Adaptation and appropriation. Londres e Nova York: Routledge, 2006.

SELWYN, Francis. Hitler's Englishman. London: Routledge, 1987.

SZONDI, Peter. Teoria do Drama Moderno. Trad. Luiz Sérgio Repa. São Paulo: Cosac \& Naify, 2001. 
STOKES, Leslie \& Sewell. Oscar Wilde: A Play. London: Secker \& Warburg, 1937.

TAYLOR, A. J. P. Beaverbrook. New York: Simon and Schuster, 1972.

WALLACE, Clare (ed.). Monologues: Theatre, Performance, Subjectivity. Prague: Litteraria Pragensia, 2006.

WEST, Rebecca. The New Meaning of Treason. New York: Penguin, 1985. WILDE, Oscar. De Profundis. London: Harper Collins, 1998.

\section{REFERÊNCIAS ELETRÔNICAS}

DUBOST, Thierry. "Kilroy's theatre of the conflicted self". Irish University Review: a journal of Irish Studies, 2002. FindArticles.com. Disponível em: <http://findarticles.com/p/articles/mi_hb162/is_1_32/ai_n28971093/> Acesso em: 05 Jun, 2010.

GRENE, Nicholas. "Staging the self: person and persona in Kilroy's plays". Irish University Review: a journal of Irish Studies, 2002. FindArticles.com. Disponível em: $\quad$ http://findarticles.com/p/articles/mi_hb162/is_1_32/ai_n28971099/> Acesso em: 05 Jun, 2010.

MASON, Patrick. "Acting out". Irish University Review: a journal of Irish Studies, 2002. FindArticles.com. Disponível em: <http://findarticles.com/p/articles/mi_hb162/is_1_32/ai_n28971105/> Acesso em: 05 Jun, 2010.

MCMULLAN, Anna. "Masculinity and masquerade in Thomas Kilroy's Double Cross and The Secret Fall of Constance Wilde". Irish University Review: a journal of Irish Studies, 2002. FindArticles.com. Disponível em: 
<http://findarticles.com/p/articles/mi_hb162/is_1_32/ai_n28971104/> Acesso em: 05 Jun, 2010.

MIKAMI, Hiroko. "Kilroy's vision of doubleness: the question of national identity and theatricality in Double Cross". Irish University Review: a journal of Irish Studies, 2002. FindArticles.com. Disponível em: <http://findarticles.com/p/articles/mi_hb162/is_1_32/ai_n28971102//> Acesso em: 05 Jun, 2010. 